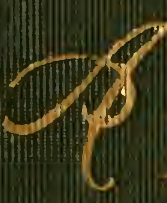

(b)
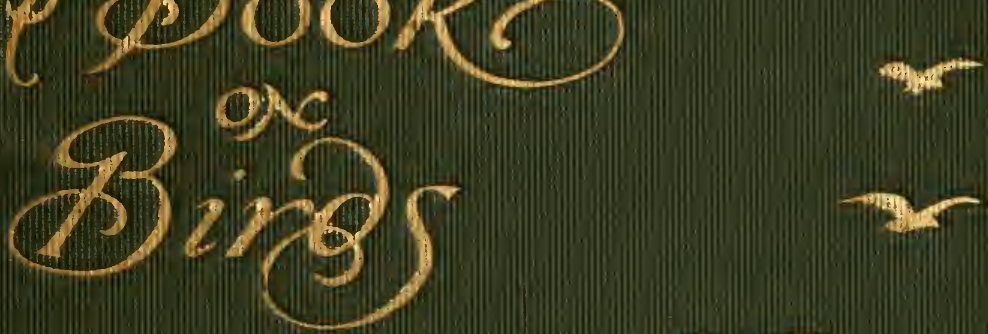

-
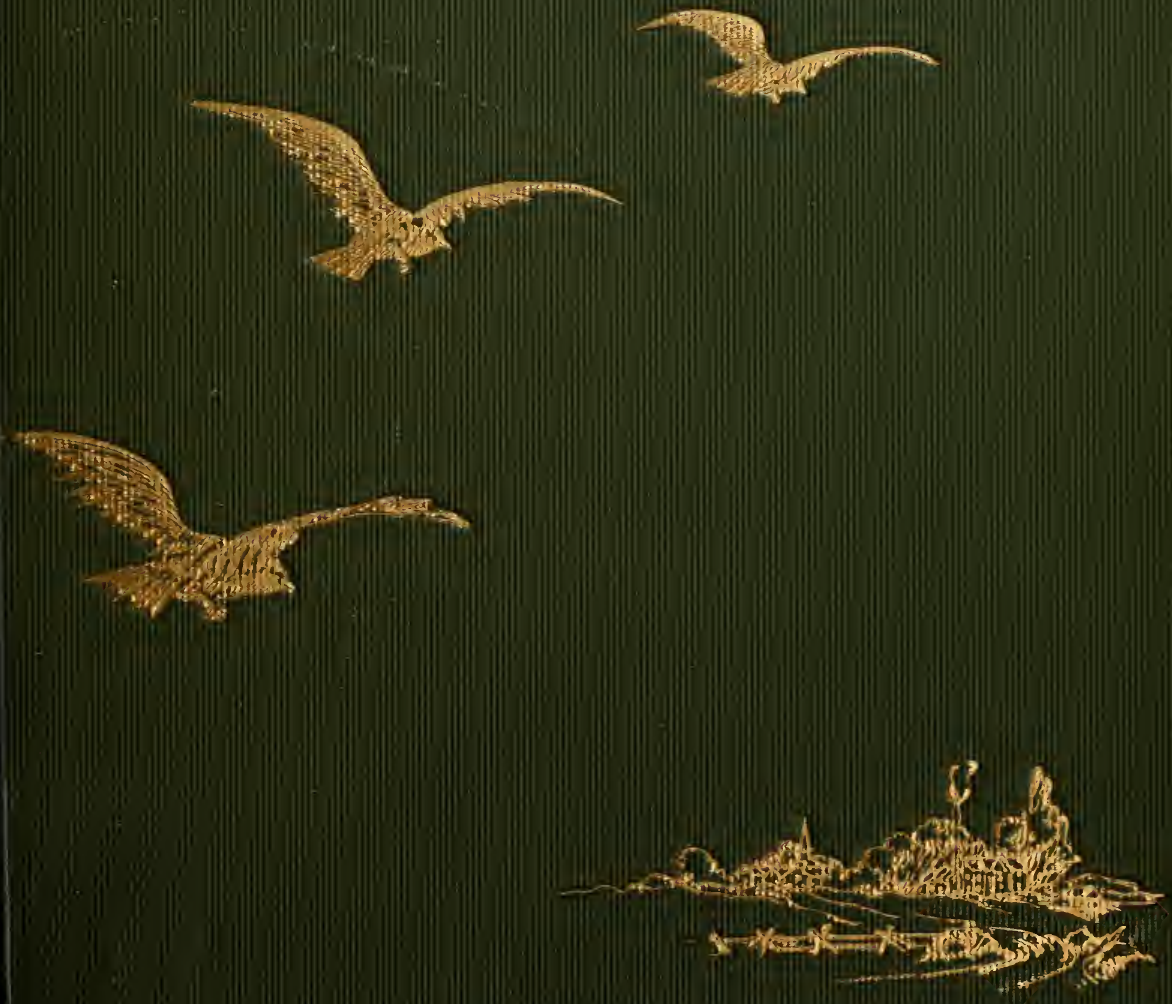

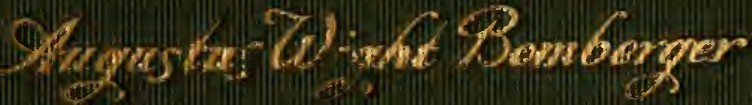




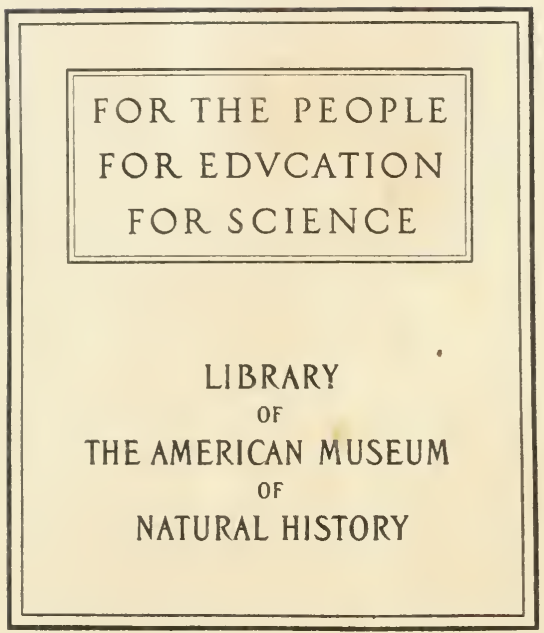




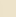





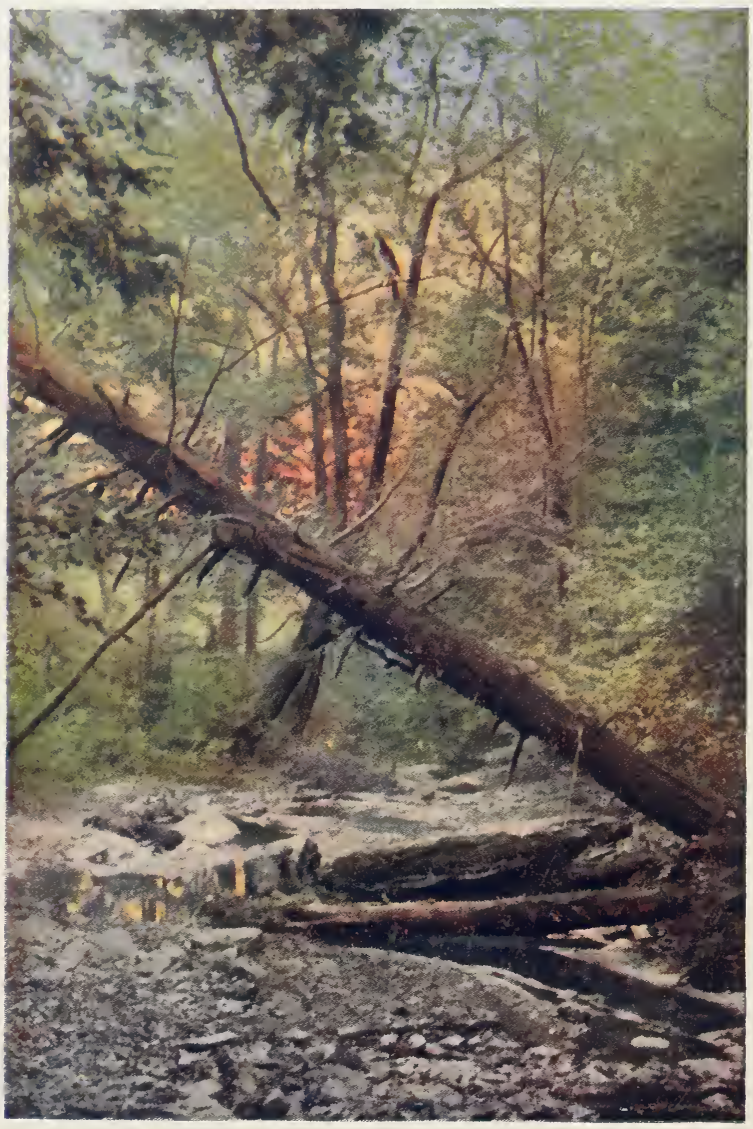

A Haunt of the Browy Thrasher 


\section{A BOOK ON BIRDS}

\section{$82,6 \%$}

BY

AUGUSTUS WIGHT BOMBERGER, M.A.

Jllugtratro with łhotngraphs frmm Tife

By WILLIAM L. BAILY

PHILADELPHIA

THE JOHN C. WINSTON COMPANY MCMXII 


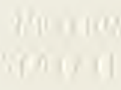

Copyright, 1912, by

THE JOHN C. WINSTON CO.

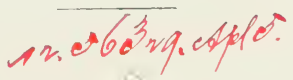




\section{CONTENTS}

INTRODUCTION . . . . . . . . 9

I. Suggentions . . . . . 15

II. Other Hints for the BeGINNER . . . . . 25

III. Bird Notes and Their Value 34 IV. In the Wake of the Brown Thrasher . . . . . 56

V. Rainy Weather and Wrens 72

VI. The Wood Warblers . . 83 VII. Tanglewood Lane and Skippack Creek . . . . . 93

VIII. Two Vireos and Some Friends 110 IX. At the End of June . . 119 X. Bird Songs After Dark . . 129 XI. Midsummer Memoranda . 136 XII. Birds on the Wing . . . 163 XIII. Dick . . . . . . . 175 XIV. IN Winter . . . . . 181 XV. Field Key . . . . . . . . 195 


\section{ILLUSTRATIONS}

A Haunt of the Brown Thrasher

PAGE

Frontispiece

Loath to Leave Her Nestlings

A Bluebird Watching Both Them and

Their Visitor . . . . . . 21

Hungry and Cynical

Sparrow Hawk . . . . . . . . . 32

Some First Fruits of Spring

Young Crows . . . . . . . . 37

Robin's Nest in a Rail Fence . 39

"Old Sam Peabody's" Home

Nest of the White-throated Sparrow . 46

The Catbird When He's Surly . 48

OH, So Sleepy!

Young Phœbes . . . . . . . . . 53

Proving His Equilibrium

Kingfisher Twenty-three Days Old . 55

Breast to Breast with Mother Earth

Nighthawk on Eggs

$$
\text { [v] }
$$




\section{Illustrations}

PAGE

The Eternal Vigilance of the Robin 64 At His Ever Open Door

The Flicker . . . . . . . . . . . 85

The Last Meal at Home

Chestnut-sided Warbler and Young . 96

A Hermit Thrush's Hermitage . . . 101

Which Shall be First?

Catbird and Young . . . . . 103

Resentful of Intrusion

Wood Thrush at Nest . . . . 105

A Swamp-Dweller's Home

Nest of the Red-winged Blackbird . 108

Half Crowded Out

Field Sparrow's Nest Cumbered with

Cowbird's Egg . . . . . . . . 110

A Bright Glance From the Leaves

Red-eyed Vireo . . . . . . . . . 112

The Sweet Seclusion of the OvenBIRD's Nest . . . . . . 117

Three Who Would be Better Off iN

BED

Red-eyed Vireos . . . . . . . . 119 


\section{Illustrations}

PAGE

Homesick on a Cool Morning Red-eyed Vireos . . . . . . . . 126

A Kingbird on Guard . . . . 128

The Littlest Mother of Them All

Ruby-throated Hummingbird . . . 133

Only Half Awake

The Vesper Sparrow at Home . . . 134

Where Snowbirds Spend the Summer

Nest of the Slate-colored Junco . . . 143

The Chipping Sparrow . . . . 144

Female Kentucky Warbler . . 165

Nest of the Nashville Warbler . 176

The Daintiest Bird Building Any-

WHERE

Nest of the Wood Pewee . . . . . 181

Surrounded by Laurel on the Edge

OF A WoOD

Nest of the Towhee. . . . . . . 192

Swamp Sparrow's Nest . . . . 199

Supervising a Sand Bath

Wilson's Tern and Young . . . . 206 



\section{INTRODUCTION}

7 HE acquisition of a definite knowledge 1 of birds through personal search and study in the open air has no doubt appeared in the minds of some too trivial a matter for serious attention or any large expenditure of time and energy.

And yet others have found it more important than it seems; and this-not only because of what it contains in itself, but also by reason of the many other things of value immediately associated with it.

For, to come into close touch with the very life of birds in field and forest, beside the myriad delights it gradually unfolds to the eye and ear and understanding out of one bright kingdom of earth, means also to feel the quickening thrill of all nature under heaven's great dome; so 


\section{A Book on Birds}

intimately is every other realm related to this, and so sensitive and subtle are the ties by which we ourselves have been joined to all created things from the beginning.

A genuine love of nature in its broadest, deepest, highest development-a love which reaches with wide and eager vision and extended hands toward the stars above, and out unto the uttermost bounds of land and sea, wakening, vivifying, sharpening every sense, and enkindling in the heart a warmth of interest so genial and pervasive as to make one under its influence as a soul aroused to its real self from a vague, dull dream of being - a love of nature like this must inevitably start from some first point of individual contact. And the realm of birds is quite sufficient to meet the requirement.

Indeed, we may go farther and say that no other realm offers it more attractively than this, with its enchanting allurements of music, color, motion, tenderness, and the magic of an ideal, care-free existence. 
Moreover, there is perhaps less danger of becoming a mere one-sided specialist along this line in the natural world around us than any other. It is hard to be narrow and contracted of spirit amidst the sweet and multitudinous voices of the wingéd creatures of the air, all of them filled to overflowing with much of the same pure joy that presents itself appealingly to us in the sunlit breezes of a May morning or October afternoon, the fragrant blossoms of an orchard, the varied flowers of verdant meadow and mossy wood, the melody of whispering trees and running brooks, the mighty outlook of hill and mountain, and the boundless sweep of the ocean. And many to whom, perchance, this joy has been as nothing will be led unconsciously by the gentle persuasion of it in birds into a high and liberal frame of mind, which, taking note of all things though pursuing but a single quest, will finally embrace all in a large and generous comprehension and capacity.

The reader who has come only this 


\section{A Book on Birds}

far upon the threshold of my book will of course perceive its purpose at once.

It is designed to arouse and inspire, rather than instruct; to uplift and gladden the heart by moving it to enter a pleasant field of profitable diversion, rather than to impart scientific knowledge. And the author ventures to write while still but a beginner himself because he has thought he will thus keep more truly shoulder to shoulder with beginners, and thereby help them the more.

The first fresh enthusiasm of a new outlook upon things of this kind must be reckoned as no small factor in the attainment of the object he has in mind. And therefore-while not neglecting to keep close to the line of authenticity and fact in presenting his experiences, so that those who may desire to follow may do so smoothly, nor be misled; and, indeed, even trying always, for this very reason, to give an especially exact though concise description of each bird and circumstance as he has seen it-he has at the 


\section{Introduction}

same time counted of equal moment a genuine reproduction in these pages of the very atmosphere of healthful life amidst which everything here set down was revealed to him. For he knows that this alone can make the quest of birds for others just what he has found it-not a mechanical occupation at all, but a sentient delight and an absolute blessing.

And, finally, relying upon these considerations, he hopes also that the reader may not only bear with him for weaving in threads of verse here and there, but, lending a willing ear, may even be able to detect some of the birds merely pictured in the prose actually singing-if but faintly-in the rhymes that appear; so that the whole aspect of what this volume lifts up to be laid hold of may not be that of a task tending to repel, through its magnitude and detail, any who draw nigh, but rather of labor made play by reason of its kindly compensations and entire simplicity.

No reference has been made to Mr. Baily's 


\section{A Book on Birds}

work because the author believes that this will at once commend itself without a word.

Nevertheless he is not content to close these introductory paragraphs until he has added one last line of cordial acknowledgment of that gentleman's valued co-operation, not only in the matier of pictures, but also at many other essential points beyond those made plain by his quick and clever camera. 


\section{Chapter I}

\section{SUGGESTIONS}

T $\mathrm{T}$ goes without saying anywhere, but especially here, after what has been set down in the preceding pages, that the only real way to get acquainted with birds is on the spot. Book knowledge of them alone is as much unlike the knowledge you obtain directly, in field and wood, by brook and hedge, as the ideas of baseball a girl gathers from reading of it differ from those of the boy who plays the game.

Books on birds may be both interesting and instructive; and also indispensable as a help and a guide. But to find a bird for yourself, in the early morning or at sunset, and see for the first time the beauty of his plumage close at hand, and hear and learn his calls and his music, and be puzzled for a bit, and run over your mental memoranda, referring to such colored plates as 


\section{A Book on Birds}

you have been wise enough to bring along - the while your feathered enigma skips from twig to twig and poses at every possible angle; and then at last to place him surely, mark for mark, and follow his secret haunts to his very nest-this is vital and satisfying; and this only.

Each acquaintance thus acquired will stir you with the joy of new discovery. $\mathrm{He}$ is yours-you will say. You have made him so by dint of personal search and observation. The book you have at home was merely a preliminary; the achievement is your own, and to you belongs the credit of it.

This is the spirit that will ultimately make a bird-lover and a field-lover of any one. Lectures, essays, pictures-of themselvesnever; except as they incite you to pick up your hat and field-glass and start right off for the great open book of nature itself. Here you will truly master your subject, if you are in earnest, and be fascinated by it; and your scant and vague and uncertain ideas will grow, and become definite and reliable. 


\section{Suggestions}

And do not be impatient in the matter, or go on your first quest in a hurry; nor in an automobile-except, perhaps, as your means of conveyance to the actual field of exploitation. Automobiles and birds are both delightful. And if you like both, well and good. That is your matter. The point is, do not try to indulge in both with equal interest at the same time. They will not mix.

In a wooded country you can pass more birds during an hour in an average "machine" without seeing a single one of them to know it thoroughly than you could find time to study in many months.

Bird students who "mean business" and want to amount to something must walk.

Moreover, they must not expect to gain more than just a little information each trip they take. A dozen new species, vividly seen and appreciated at their full woodland value, will be rich reward for a whole year's work; and quite enough also to satisfy any ordinary observer. 


\section{A Book on Birds}

The ideal season to study birds in this climate is of course the spring, when most of them sing to a greater extent, and make themselves in every way more conspicuous than when the hot summer months set in.

This, however, is true of each locality only as to birds that nest within its limits.

For in our latitude the migratory birds can be found in large numbers in the fall also, when they often linger with us for many days in flocks on their passage southward, if the prevailing weather be propitious.

And the ideal time for best results is that "witching" hour before breakfast when the "sun peeps over the hills;" at which moment it seems to be instinctive with every bird to lift his voice in melody, even though he keep complete silence (as many do) during the heat and burden of the day. If sunrise, however, is not attractive to you, sunset will do nearly as well-provided you do not count on seeing many after the sun has actually disappeared. 


\section{Suggestions}

These, by the way, are merely the best times to go. Any period of the day, from middle-March to the depths of summer: is sure to produce some resultsthough it is surprising how few birds can be found after ten o'clock in the morning when the extremely warm weather has come.

In that part of southern Pennsylvania where I reside there lies immediately north of my home a great stretch of open, rolling country-broken into long valleys garrisoned by splendid hills and traversed by three fine streams of water, the Schuylkill, the Perkiomen, and the Skippackwhich offers as fair and prolific a field of observation in this study as anyone could desire. Of course there are in the same broad belt that takes in these streams, and for hundreds of miles to the east and west of it, other districts beyond number just as rich-and equally attractive also to those in turn who count them their own.

However, in this of mine, and it is at 


\section{A Book on Birds}

least representative, you will probably find after continued effort during several seasons, nearly ninety species nesting; while many more may be added to that total in the spring and autumn from birds of passage. And of these an average amateur, using good judgment, may get as many as forty or fifty in a half-dozen trips.

But never strive for mere numbers. Rather take a single group at a time and learn it thoroughly - so that you acquire as quickly as possible an intimate, friendly relationship with it, as it were; including perhaps some awkward ability to whistle the family language, and other woodland accomplishments.

And if, perchance, any reader should feel moved by this initial chapter, and have the impulse to "start out" at once, suppose he begin with the Sparrow family.

Not one in a score, even among those of us who love the open air, knows this charming company of songsters as he should. Indeed, there have been cases where the experts - the real naturalists 



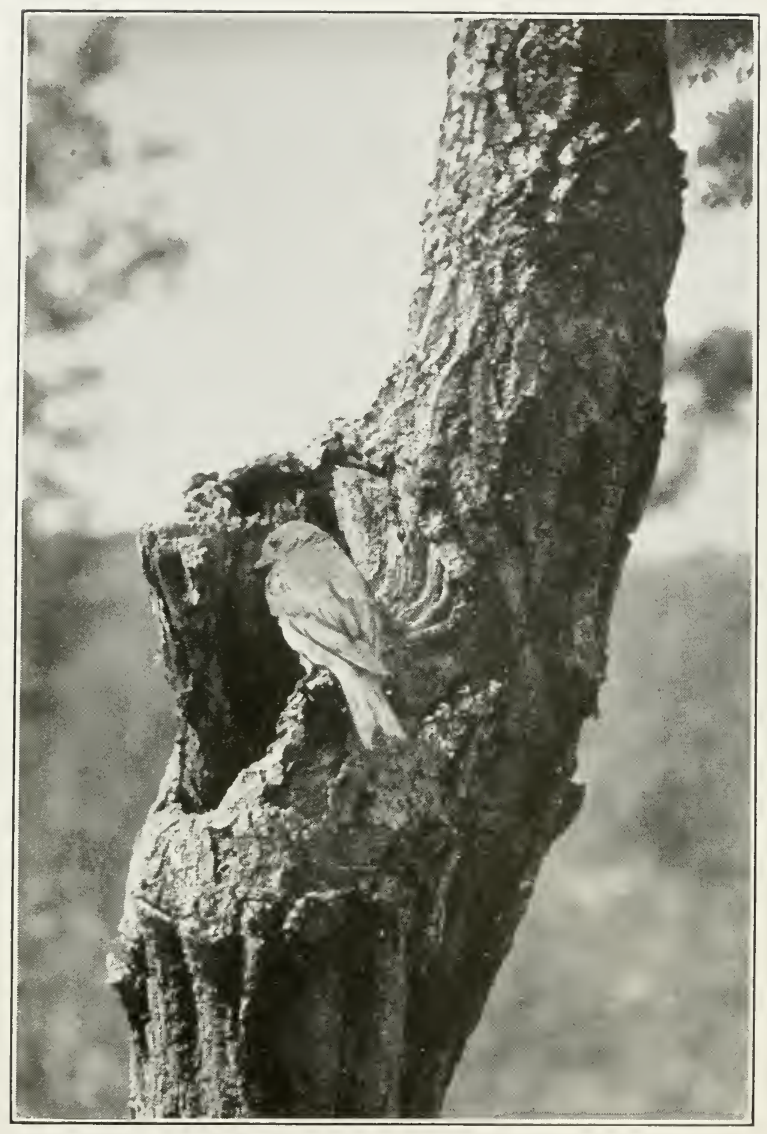

Loath to Leave Her Nestlixgs

A Bluebird Watching Them and Their Visitor

(See page 19) 
whom we all follow and admire-have fallen into mistakes over them.

And yet they are not hard to get on speaking terms with, and prove delightful little bodies when once they become familiar to the eye and ear.

There are twelve or more, all told, who honor us with their presence-though some of these are so retiring and exclusive (and, beside this, so rarely, if ever, make their domicile here) that it will take a long while, and you may lose patience at times, before you are acquainted with them.

Those you ought to know, however, and may know easily, are the Chipping Sparrow (with his mahogany-brown cap and no melody in his note); the Song Sparrow (who often stays with us all winter and furnishes our first spring music); the Vesper Sparrow, or Grassfinch (with his white tail feathers which always show as he flies away from you); the Yellowwinged Sparrow (smallest of the group, whose voice is so like that of a grasshopper he has taken his name too, and 


\section{A Book on Birds}

who can light on a tall weed with him in the center of a field and not bend it much more than he does; and whose eggs - silver-white with a wreath of brown and gold and lilac spots, circling the larger end, are about the daintiest things in ornithology); the Field Sparrow (whose evening hymn-a series of exquisite minorthirds beginning very slowly and running together at the end, like sparkling dewdrops on a blade of grass-is so plaintive and tender that once clearly heard it will never be forgotten); - these fiveand then, less easily found, the Fox, the Tree, the White-throated, the Swamp, the Savannah sparrows, and several others -not to include our town bird, the English Sparrow, who cannot sing, has bad manners, and really doesn't belong in the group at all.

Taking these to begin with, you will have plenty to do for many a day. Try it and see-not neglecting the others altogether (for you cannot do that), but making these the chief subjects of study. 


\section{Suggestions}

They will pay you well for your work; and on every trip you will get more than you bargained for-both from them and their environment.

For this does happen with those who go forth into God's great out-of-doors, bearing eager hearts and humble minds. They learn that a love of birds leads to a love of all nature, and a love of all nature to the brightest, best and happiest life under heaven. 


\section{A Book on Birds}

\section{The Heart of Winter}

Hail, Springs of life within the silent rock!

I know the secret of your hiding-place,

I hear the hidden music of your flowing,

I see the vernal sunbeams brightly glowing Above the limpid depths of your embrace.

And though no bolt of heaven nor thunder-shock

Hath aught of power to pierce your mighty prison, Yet this, this too, I know, that by and by

Some messenger of song that God hath sent

Will seek these solid walls, and find their portal,

And gently call you forth, in faith immortal,Will gently call till every bar is rent, And Earth awakens with the joyful cry, "Behold, behold-the Springs of life are risen!" 


\section{Chapter II}

OTHER HINTS FOR THE BEGINNER

70 show from actual experience how close and accessible to a bustling town is the bird life we would know, even upon an entirely un-springlike day, let us proceed by a street in its outskirts this breezy afternoon early in April, starting about five o'clock, and walk toward the west until we reach the country, there picking a road to the right at a big, restful-looking house that stands amidst some tall pines, and following it past an old brick-works to the first cross-fence beyond, as we go.

Here, the rails being down invitingly, let us take to the fields.

Now, on such a quest as ours, there are two good reasons for doing this just at this cross-fence, in addition to the alluring attitude of the rails. 


\section{A Book on Birds}

First, the fence is hedged upon either side-at some points to the depth of ten feet-with a thick growth of sassafras, elder, wild-cherry, hickory, blackberry brambles, and "other things too numerous to mention;" and if there is one place which certain birds love more than any other, and particularly in cool, windy weather, it is a cross-fence thus reinforced.

And, second, the fence is the boundary line of a broad meadow and leads gently down, after a hundred yards or so, to a little stream of running water, fringed with more elder and "other things," and just of the sort to which these same birds delight to come at evening-time to drink. So we keep to the cross-fence.

And, sure enough, here are some, to start with at least-even if they do happen to be merely Snowbirds that have been around all winter. They are recognizable most easily by the light pinkish-yellow of their broad beaks-which looks conspicuous against the dark slate color of head and back and wings. 


\section{Other Hints for the Beginner}

They engage us quite a little timefor they will be taking their annual trip northward by and by, and we and they may not meet again for a while.

However, the minutes are precious this afternoon, and we must proceed.

And now, because the rivulet happens to spread a little farther on, where the fence meets it, to somewhat of a morass, too wide to cross, we are forced into a short detour out through the open, until we sight a rough foot-bridge of old rails, laid from bank to bank, and head for it.

But just here are other friends to make us forget those left behind. And a fine pair at that, whom, perhaps, you do not know; to wit, two plump Killdeers-slaking their thirst amidst the tall brown winter grass.

They seem not to notice our approach until we are quite near, and then they start to run away from us, going rapidly, and keeping as close to the ground as chipmunks, and all the while looking back shrewdly-this being a characteristic performance of the Vesper Sparrow also. 


\section{A Book on Birds}

We follow-walking fast but very stealthily-and they do not break into flight until they reach an intercepting lane, across which they wing their way, uttering the quick, agitated cry from which they take their name- "Killdeer, killdeer, killdeer!"

They fly with an eccentric, irregular motion, their dark pinions (with a crook in them) showing snowy white underneath as they go.

In thus proclaiming their name they are like a number of other birds that are quite easy to identify simply because they announce themselves in this way to all strangers who are on the alert to hear. Indeed, almost immediately, we come upon another feathered friend (also not as well known with us as he might be) who does the same thing - the Towhee bird.

This fellow reveals himself at the fence (to which we have now returned) on the other side of the meadow-brook. $\mathrm{He}$ is probably first of the season, and his voice is not strong as yet. But try to articulate 


\section{Other Hints for the Beginner}

the word "Towhee" in a whistle, and you have it exactly.

We find him handsome in appearance, when we finally get a good glimpse. $\mathrm{He}$ is a little smaller than the Robin; with black head, throat, back, tail and wings; the tail and wings, however, greatly enriched by glistening white feathers. His shoulders and sides are brick-red, while his breast is of pearl, and his eyes of a brilliant ruby. He was in this hedge last summer and has come to almost exactly the same spot for another season.

For this, also, is a trait many birds have that will help you in finding and getting acquainted with them.

A Wood Warbler not much bigger than your thumb will fly many miles from the South during a night and arrive in the early morning at the very haunt-on the very limb perhaps-he picked for himself the year before, and know it just as well as the tired boy who has been out all day knows his own home after dark.

With this trait to count on, every wise 


\section{A Book on Birds}

bird-lover will soon have a locality for many a species, and govern himself accordingly in his expeditions.

After getting the Towhee to repeat himself a half dozen times by imitating his call, we walk on to a point where another fence, even more deeply hedged about, meets the first at right angles on our left. Jumping over, we explore this too, finding Song Sparrows, Chipping Sparrows and Field Sparrows, with a Sparrow-hawk sailing around overhead, with a sharp eye on them, no doubt, for other food is scarce as yet; and then we cross a broad field, still going westward, to a thick patch of secondgrowth timber about fifteen feet high (with a few old oaks still standing amongst it) which lies on the other side.

We pass a score of Meadow Larks and Robins on the way, and in the timber find Blackbirds and Crows galore. The young trees stand close together, and the brown, leafy mold under foot is brightly carpeted with the rue anemone, blood-root and spring beauty, all in 
Other Hints for the Beginner

bloom, with the tender green leaves of the May apple peeping through everywhere. The spring beauties have already gone to sleep in the woody twilight, although it is only half after five by this time; but the others, including a stray hepatica here and there, are still almost as wide awake as ever. After gathering up a few of the widest-awake ones, we leave the trees and start homeward by the same route we came.

Two Golden-winged Flickers greet us as we emerge-they also, by the way, crying out their names; and we hear a Bluebird's soft elusive note and sight him sitting atop a fence post.

On our way across the meadow again an enthusiastic Red-winged Blackbird circles overhead and sings his flute-like "og-ill-ee" refrain for our especial benefit; and near the road, on an old rail, we find the first Wren we have seen this season.

By quarter after six we are back again at our starting point, having checked fifteen different species on our bird list in

$$
\text { [31] }
$$




\section{A Book on Birds}

a walk of less than a mile and a half, and in but little more than an hour's time. And this, quite ahead of the season also; the walk we have described having been taken in April, as stated, with results precisely as here set down.

Let anyone cover the same course at the same hour one month later and he will meet from two to three times as many varieties among the feathered songsters he seeks, provided, of course, he knows how to go about it.

For then the Thrush family, and Swallows, and Orioles, and Wood Warblers, and Vireos, and Flycatchers, and Pewees, and many others will have arrived once more, to make field and hedge and blue sky, and the thick growth of new timberby that time a mass of fragrant foliagejust as glad as ever before, in vernal days gone by. 


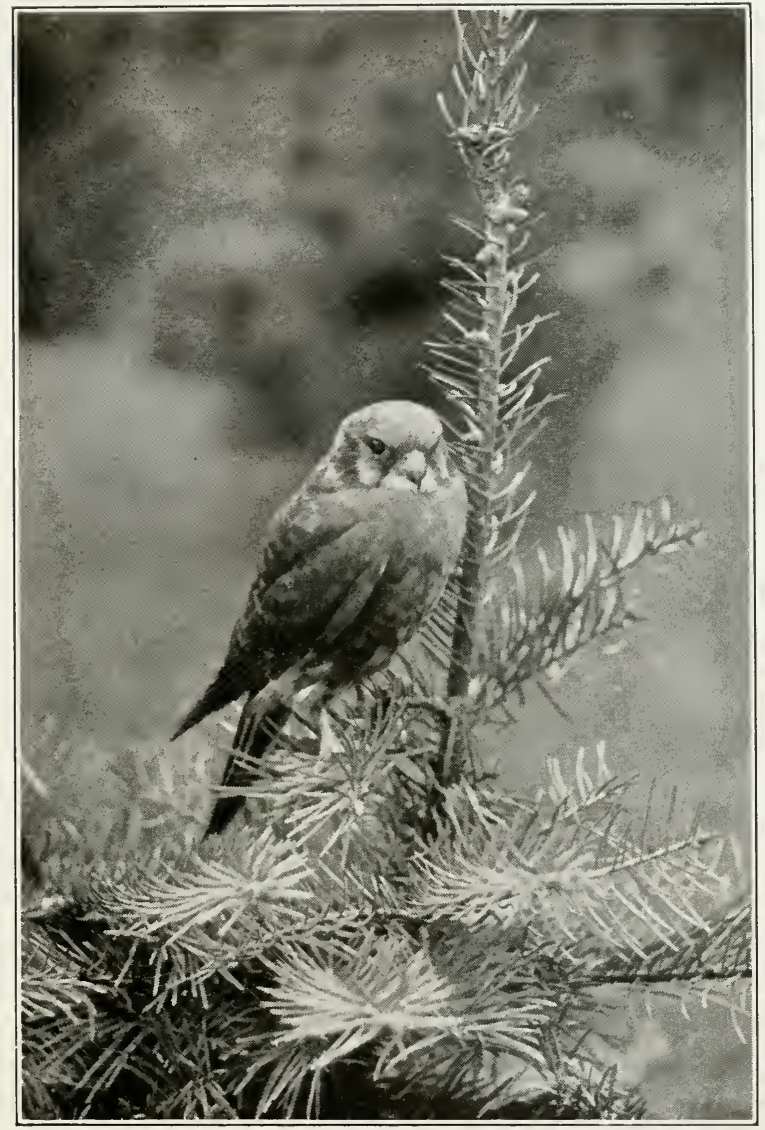

Hungry and Cynical

Sparrow Hawk

(See page 22) 



\section{In Joyous Faith}

\section{IN Joyous FaITH}

In joyous faith, from mountain top and vale, Hark, hark, they come-the myriad birds of spring!

Swift as an arrow, at the Master's call

They pierce the frozen air with steady wing, And laugh to shame the winter winds that rail

Against the precious promises they bring.

They wake the lonesome wood with sound of song;

They stir the drowsy violets with mirth, And send a thrill of gladness into all

The dark and mournful silences of earth; Until at last, a sweet, exultant throng,

They swell the triumph of perennial birth.

Oh, wondrous miracle of victory!

In joyous faith they win-and so may we. 


\section{Chapter III}

BIRD NOTES AND THEIR VALUE

TWO Robins, engaged in nest-building directly across the way from my home, have started me to thinking about bird notes this morning.

The leaves everywhere have but just emerged and are still little more than a delicate mist of green over the trees. Yet a spell of exceptionally warm weather, following close upon a snow-storm and lasting a fortnight, seems to have developed certain native proclivities in these two with such unusual rapidity that they have gotten ahead of the foliage; and, unable to wait for its privacy and shelter, have begun work on their home in the topmost fork of the unadorned branches of a maple, where every detail of their proceedings is quite open to the public gaze.

However, as I have indicated, it is 


\section{Bird Notes and their Value}

not so much what they do that engrosses my attention just now, as the wonderful amount of melodious noise with which they enliven their labors.

Some of it, without any doubt, is simply music. But much more appears to have definite meaning and purpose beyond this.

As I listen I count seven distinct strains or sets of notes which they use repeatedly; and these, furthermore, are marked by many minor inflections and variations, all plainly forming the medium through which they communicate the one with the other. It must be admitted, of course, that it is all a very crude sort of language; nevertheless it seems entirely sufficient to enable them to get along quite smoothly, delightfully, and with a perfect understanding of what each is to do, as they put together their rough, though strongly constructed habitation of mud and hay.

Moreover, I know well, from a long acquaintance with the species, that the warbling conversation of this pair constitutes only part of the general fund of 


\section{A Book on Birds}

robin talk and robin music. Other

Robins (and even these, no doubt) have many other notes and strains for other experiences.

For example, in an entirely different case of nest-building that came under my observation the male bird, unless my eyes deceived me, did very little, if any of the actual labor, confining himself instead to a sort of bustling superintendence of things; and the notes here seemed to be altogether in keeping with just what might be looked for under such conditions. And again; I have felt frequently that there is no bird-cry in all the world which is more truly intelligible than that of a Robin bemoaning the loss of its youngling or its mate. Often, as it drops to a cadence almost inaudible, it is so acutely appealing that it has appeared to me the perfect intonation of hopeless grief.

Several years ago a friend of mine was brought by this fact into an experience having almost enough in it to move one to tears of sympathy. Upon a stone 


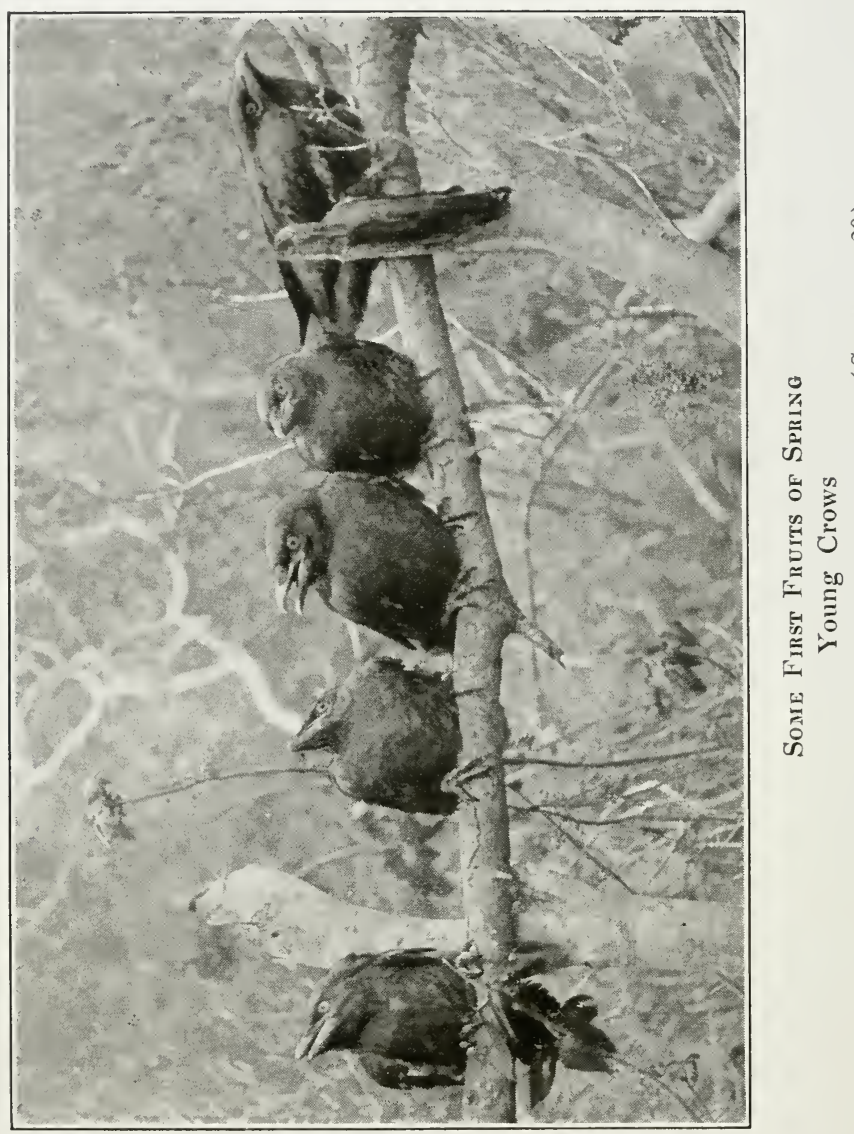

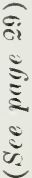




\section{Bird Notes and their Value}

step of the approach to a residence near my home he came across one of these birds standing beside its partner, lying dead. Drawn close to it by the heartbroken woe of its voice, he discovered to his surprise that it was so utterly engrossed with its sense of bereavement that he was able to bend down and stroke its feathers (even while the bird itself stroked with its beak those of the inanimate form it loved) without any apparent sign of consciousness in the bereft one of what my friend was doing.

It is not to be wondered at that a Robin's notes of mourning so reach the soul sometimes, when upon occasion they can spring from a grief as absolute as was exhibited here.

But these random reflections are, of course, aside from the main purpose of this chapter.

Bird music has other-practical-values for the ornithologist, beyond whatever expression of joy or sorrow, or anything else of this nature informing to the human 


\section{A Book on Birds}

mind, it may contain. And (the industrious pair of Red-breasts opposite having disappeared for a bit) let us consider some of these, during their absence, in a more general way.

It will appear at once that all our questing, considered merely for its purpose of adding to our acquaintance with birds, will be simplified and become easier as we get clearly familiar with every possible song and call as we proceed.

In many cases, of course, reliable knowledge of this kind is difficult to acquire and will come only after extended experience. Yet in just as many more it may be gained upon the very threshold of things; and long before you have reached that expert stage where you can invariably distinguish (let us say) the music of the Song Sparrow from that of the Grassfinch, you will have found, if patient, that you have picked up a great deal of other skill that is well worth while; birds, which else would confuse you and escape identification, now fixing themselves surely, 



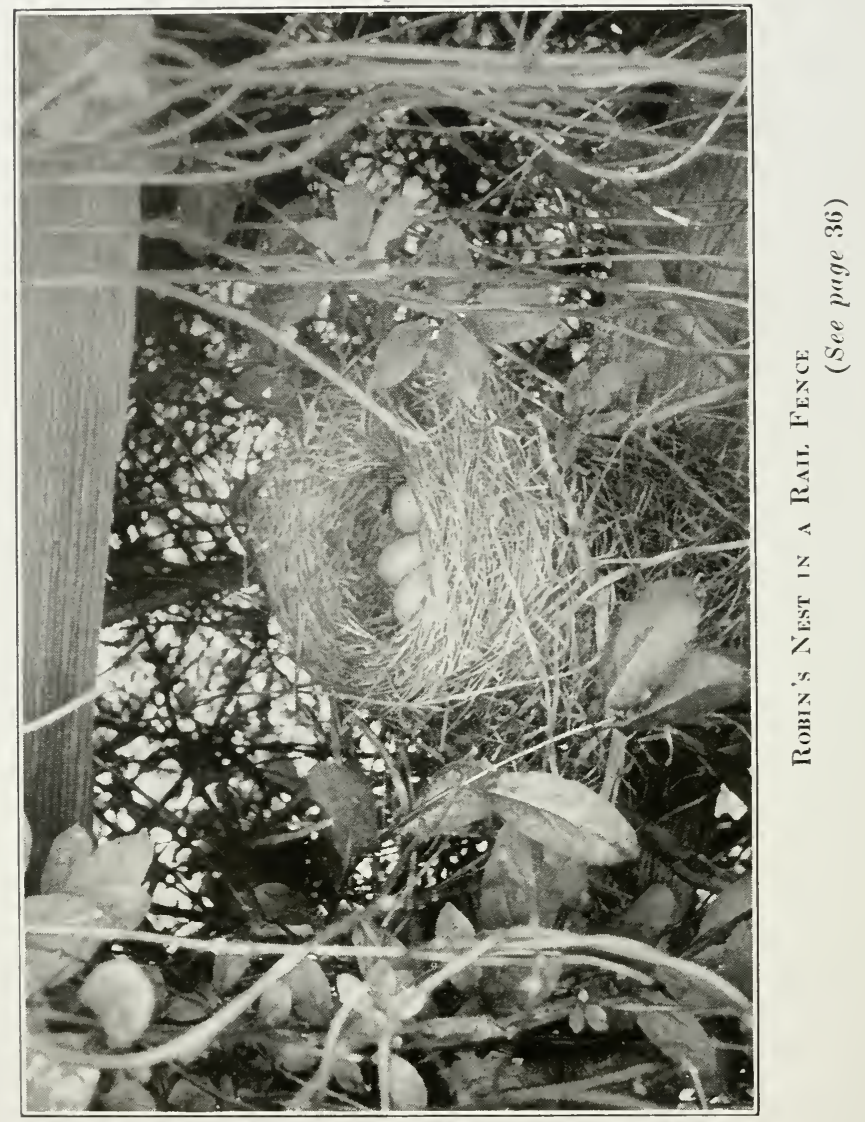




\section{Bird Notes and their Value}

ever and anon, the moment they give voice.

This is likely to prove a source of increased satisfaction upon nearly every new trip you take; and especially if your progress be interfered with at places by dense foliage, or the trip be continued, perchance, into the dusk of eveningconditions under which even good eyes and field-glasses are of little account.

In addition to my own limited acquirements along this line I have chosen a method followed from time immemorial by wiser ones than I, and learned that it helps greatly to associate many songs the moment your ear has them alertly, with names and words which these others have found in them, or even names and words of your own. The whistling Bob White (Quail), the Teacher-bird (Golden-crowned Thrush), the Peabodybird (White-throated Sparrow), the Phœbe (Bridge Pewee), the Towhee (Ground-robin), the Bobolink, and the Killdeer are most familiar among the birds that actually 


\section{A Book on Birds}

fling their identity at you, more or less melodiously, every time they open their mouths to sing. And if you fail to get acquainted with these very early in your career, it will not be their fault at all.

Then there are many others to whom poets, and prose writers also, though they have not in fact given names, have attached delightful words and phrases that will cling to them always and will assist you just as much in your questing.

The Maryland Yellow-throat, for instance, first discovered himself to me only when I realized, with sudden pleasure, that he was warbling, "Witchery, witchery, witchery, witchery!" over and over again.

Moreover, he indeed was one of those with whom I made assurance doubly sure, and satisfactory, by permitting my own personal fancy and power of invention to participate in the experience-the bird seeming, after a while on this well-remembered occasion, to say, "Jessica, Jessica, Jessica, Jessica!" to a certain member of our party quite as plainly as the other 


\section{Bird Notes and their Value}

word just quoted by which he is more generally known.

This appreciation of the value of bird notes in your search and study may naturally be followed into many other details.

To illustrate: one can get into the habit of judging the variations in key and rhythmic time of this bird song and that, and know them instantly by points of similarity and contrast. As an example here - the one-two-three "Bob White" call of the Quail, above mentioned, and so familiar to all, is pitched generally in the same tone as the notes of the Crested Flycatcher, a bird not so well known to many, but whom you will be quick to recognize when this is remembered, because his strain is altogether different in other particulars.

And again, many notes and strains will become easy to differentiate if you keep your ear and heart open to whatever human emotions and special traits of character they seem to express and convey. I have already discussed the Robin's notes. 


\section{A Book on Birds}

To me his only accomplishment worthy to be called a song-the brief, warbling canticle he repeats endlessly morning and evening -is simply brave, trustful joy, in its most primitive outpouring; and the Wild Dove's strain-is resignation to sorrow; and the Blue Jay's strident cry - hate and cynicism; and the Kingfisher's "clack-e-ty-clack"-reckless, superficial jollity; and the Meadow Lark's clear callserene contentment, with the Bluebird's faint, ethereal voice as its lovely echo.

As for others-when my approach drives the Catbird from his nest the noise he emits is pure surliness to my ear; when he is singing all alone, unaware of my presence, it is pure bliss. I know and love the Wood Thrush especially (above other noble traits) for the religious devotion of his evening hymn; and the Hermit, just a little more for an even deeper reverence. The mellow richness of the Scarlet Tanager's scant melody appeals to my mind as the warmest passion of the woods; and so onand on, to the end of the long, sweet list. 


\section{Bird Notes and their Value}

Then, to turn to a different class of characteristics, I find, say, that some bird (like the Indigo Bunting) sings in a hurry practically the same strain that another (like the bright American Goldfinch) takes far more leisurely; and in such cases comparison helps me in telling which is which. Or, the Bobolink is a glad, effusive fellow; and the merry House Wren, with his spluttering crescendo, nothing more than a dear little stammerer.

And last-and shall I say best of all?the Field Sparrow is naught less to me in his music than a quiet stringer of pearlsliquid pearls of peace, arising in his breast with no effort and issuing one by one from beginning to end without a ripple. I have heard him keep at it at intervals of a minute or so from the same spot for nearly a half-hour-the while I approached within thirty feet of him from every side and watched through my glass at every angle; and all the time he appeared utterly undisturbed by my presence. The notes, as to time and rhythm, are not 


\section{A Book on Birds}

unlike those of the Chipping Sparrow; but the latter lack entirely that flawless music which makes the others so beautiful.

I am free to admit that impressions received by my readers in these and other cases may differ, more or less, from my own, with each individual; but, whatever they may be, if you retain them as they are made, they cannot fail to help you much in securing sure data and verifying it pleasantly, over and over again.

But, let this suffice by way of mere disquisition-at least so far as the present chapter is concerned.

A week has passed; the warm weather has continued; the two Robins have about finished their nest; and we are now away out in the open, in an effort to prove what we have been saying by finding the Whitethroated Sparrow from the sound of his voice - a voice that is distinctive because at this time of the year it is probably the littlest and squeakiest under heaven.

That first bright patch of gold we are 
Bird Notes and their Value

coming to in the dry marsh beyond these sparse blackberry brambles, with their but half-grown leaves, is the yellow fieldmustard; and the other, larger one, fifty paces farther on, of a deeper, richer hue, is the meadow-parsnip.

As we pass them, going toward the woods, we notice that the mustard bloom is in racemes about the size of a long thimble and the parsnip in flat clusters, like elderberry blossoms, but smaller.

And directly we think what a pity it is that these bluets carpeting the ground hem us in so that we cannot go around them, but must trample them under foot!

Yet what does it matter, after all? This is a bird-quest we are following just at present, and other things must not be permitted to divert us; for it is nearly sunset and if we would have other light than that of the stars in returning we must keep right at it and hurry.

Which we do-and are rewarded even earlier than we thought to be; for we have hardly entered a narrow, fragrant path 


\section{A Book on Birds}

which leads through some hazel bushes and tall buttonwood trees before the sharp, thin chirp we have been expecting pierces the ear from either side of us; and in a few moments we succeed in locating several of the chirpers themselves, and can scrutinize them adlibitum through our spyglasses.

And what beauties they are!-certainly the handsomest, and almost the largest of the Sparrow family.

The cleanly contrasted stripes of alternate brown and white (we count three of the former and two of the latter) straight back from the beak across the crown of the head seem to me their most striking color mark, even though the broad patch of white at the throat is quite distinctive. And, indeed, very conspicuous also, to my mind, are both the pure steelgray underneath the flashing black eyes, and the squirrel-like shades of back and tail.

But it was the voice of the Whitethroated Sparrow which brought us out 


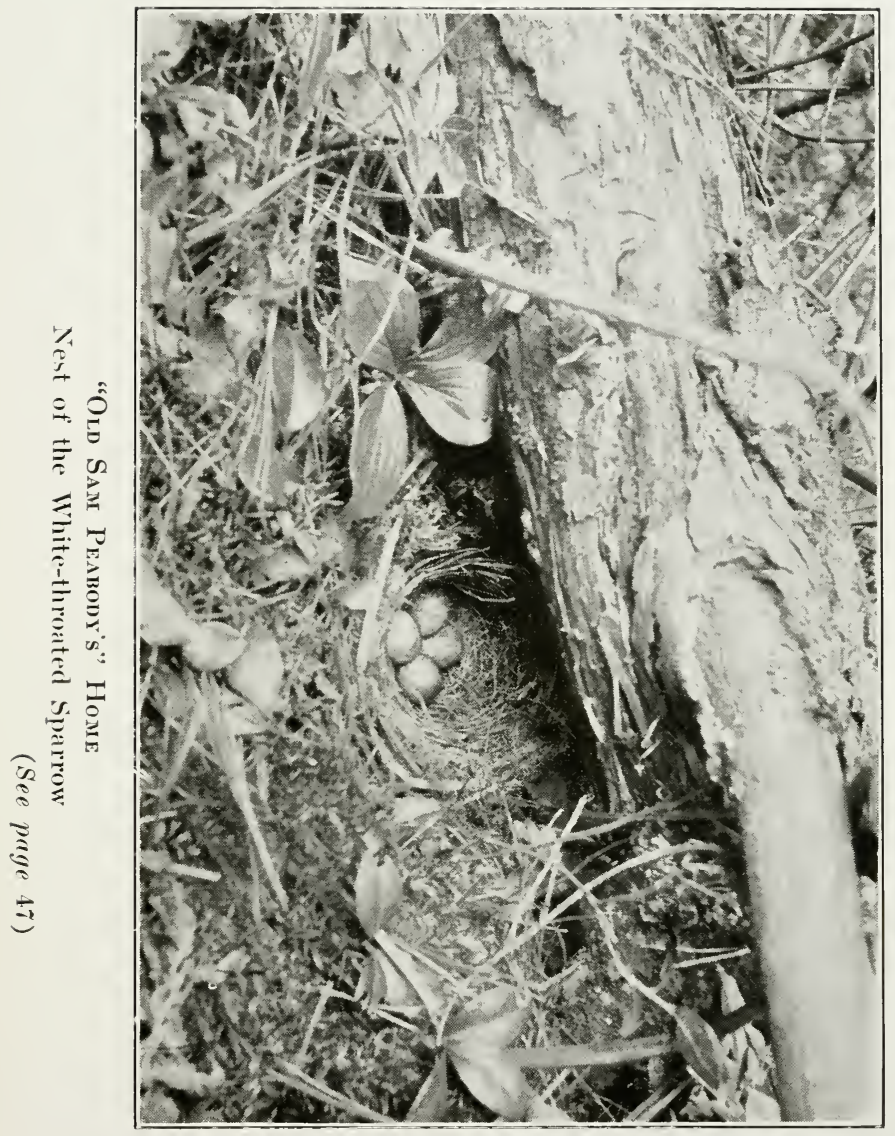





\section{Bird Notes and their Value}

this afternoon. And it is truly exceptional. Some notes of it are in the very highest pitch to be found among birds or animals. Naturalists who have measured them carefully, declare that they are actually four full tones above those of the Hyla (Pickering's frog), which otherwise hold the record-being uttered "in the note $\mathrm{E}$ of the fourth octave above the middle C."

With us the bird is mostly migratory, nesting, as a rule, in the Pennsylvania mountains and the latitude of middle and northern New England; and while passing through our fields and forests he generally has but this one call which we are now hearing every half minute, or oftener. But now and then even with us, and daily when once he gets to his real home, he launches forth into real music, even though some of it is keyed up to a sort of White Mountain altitude; and because this full song of his has been thought to sound like

"Old Sam Peabody, Peabody, Peabody!" 


\section{A Book on Birds}

he has been given the other name we have mentioned in a preceding paragraph - "the Peabody-bird."

And now-although it be a digression from the special purpose of our trip and the theme of this chapter, let us yield nevertheless to the lure of the wild and cast about in a general way for other newcomers, while the twilight still permits.

These two little fellows hopping about incessantly among the virgin leaves of the big gum tree, just beyond the bushes where the Sparrows first announced themselves, are Myrtle, or Yellow-rump Warblers. The Magnolia Warbler has a "yellow rump" too; but these have in addition a bright saffron spot on the crown of the head which always fixes their identity positively. Besides, the black along the eyes, and the exquisite gold on the upper part of a breast dappled and streaked with rich brown, are marks clearly their own.

Turning from the Warblers we notice that some of the other smaller birds seem 


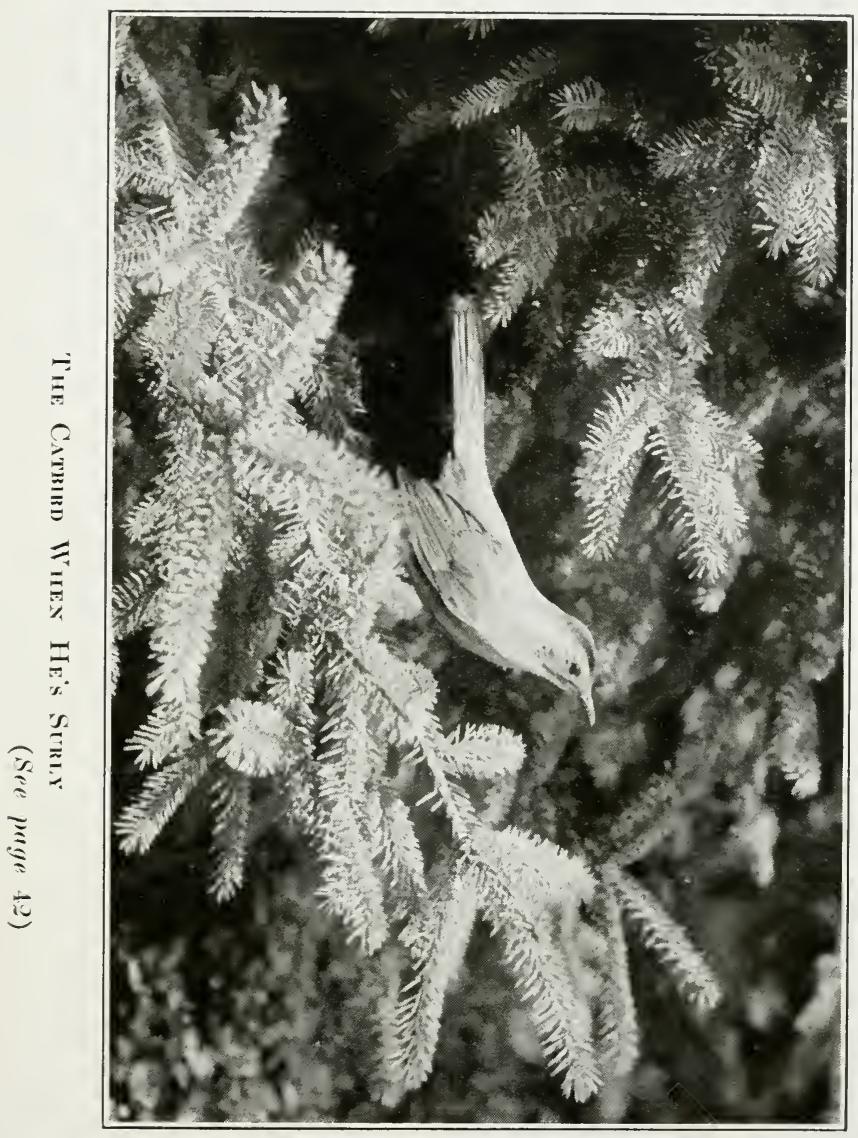





\section{Bird Notes and their Value}

to take a special delight in the lavish white flower-clusters of the black haw that show through the thicket in three or four different directions. Even the Goldfinch ("Wild-canary"), who appears to be everywhere, swoops down to them occasionally from the higher branches which spread above these dwarf blooming trees, and greatly enhances their beauty in his lovely spring garb of yellow and black, which has taken the place of the poor dun and gray vestments he wore during the winter.

What it is he and the others are finding in the black haw that pleases them so is a secret I cannot guess.

Listening suddenly with closer attention

I hear from some distance back of me a call that is quite unmistakable, and most agreeable to the ear after so many months without it-that of the Phœbe, or Bridge Pewee, to whom we adverted some pages back. He is easy to recognize just now even if you do not catch his voice. For, in our climate, whenever this early in the 


\section{A Book on Birds}

season you come across a small feathered specimen who has a trick of swooping across from one tree to another with a quick, snapping sound midway, as he goes, you may be sure it is he. None but flycatchers behave this way, and the Phœbe is the only member of the family who reaches us so soon-the others, including the Kingbird, the Wood Pewee, the Crested, the Acadian and the Least flycatchers, not arriving until many weeks later.

In a few moments $I$ find at the far end of the woods the very one who is calling. $\mathrm{He}$ is dull of color, but lively of disposition; is just a little larger in size than the Song Sparrow, and places his nest (with its snow-white eggs) against some wall supporting a bridge or beneath the shelving rocks of an embankment. I knew one nest even under the eaves of a house, at Valley Forge; for the Phœbe is often very companionable indeed.

In the immediate rural environs of my own town, he and the Crested have for several seasons availed themselves of the 


\section{Bird Notes and their Value}

peculiar advantages for home-building presented by the tumbling walls and other ruins of a fire-swept tack-works, closely surrounded by trees and bushes. The Phœbe picks out the crannies of the dismantled engine-house as exactly to his fancy; while his cousin and friend uses the deep recesses of an open stove-pipe protruding from the half-demolished gable of another building, finding it no doubt just as rain-proof as his traditional hole in a tree-and quite as comfortable.

Upon a hurried investigation, made one day while the latter was off on a visit, I discovered that he still indulges himself the queer and inexplicable eccentricity of weaving snake-skins into his nest which his forbears probably had, even as far back as the days of Noah.

However, (eccentric, or not) this same Crested Flycatcher is assuredly a most beautiful and distinguished-looking birdthe coloring of his plumage being so exquisitely delicate and varied as to defy intelligible description. Its most striking hues are 


\section{A Book on Birds}

the dull olive of the back, the ashen blue of the throat, the bright sulphur yellow of the breast, and the rare, pinkish-brown beneath the long tail-feathers. Though a trifle less in size than the Robin, his fine crest makes him look larger, and gives him an aspect of great energy and animation.

But dinner waits!- and I am still out in the fields a mile away. Hurrying homeward, I notice that the two Belted Kingfishers, whose acquaintance I made years ago along the winding reaches of that Stony Creek I love, have reappeared in their old haunts a week or two earlier than usual. They are in splendid spirits and have evidently had a good winter-probably spending it not very far south. You can always be sure of their presence before you see them from their cry, which is an exact reproduction of a watchman's rattle, heard at a distance.

They start up hurriedly upon my approach and skurry along above the surface of the water in precipitate flight; 



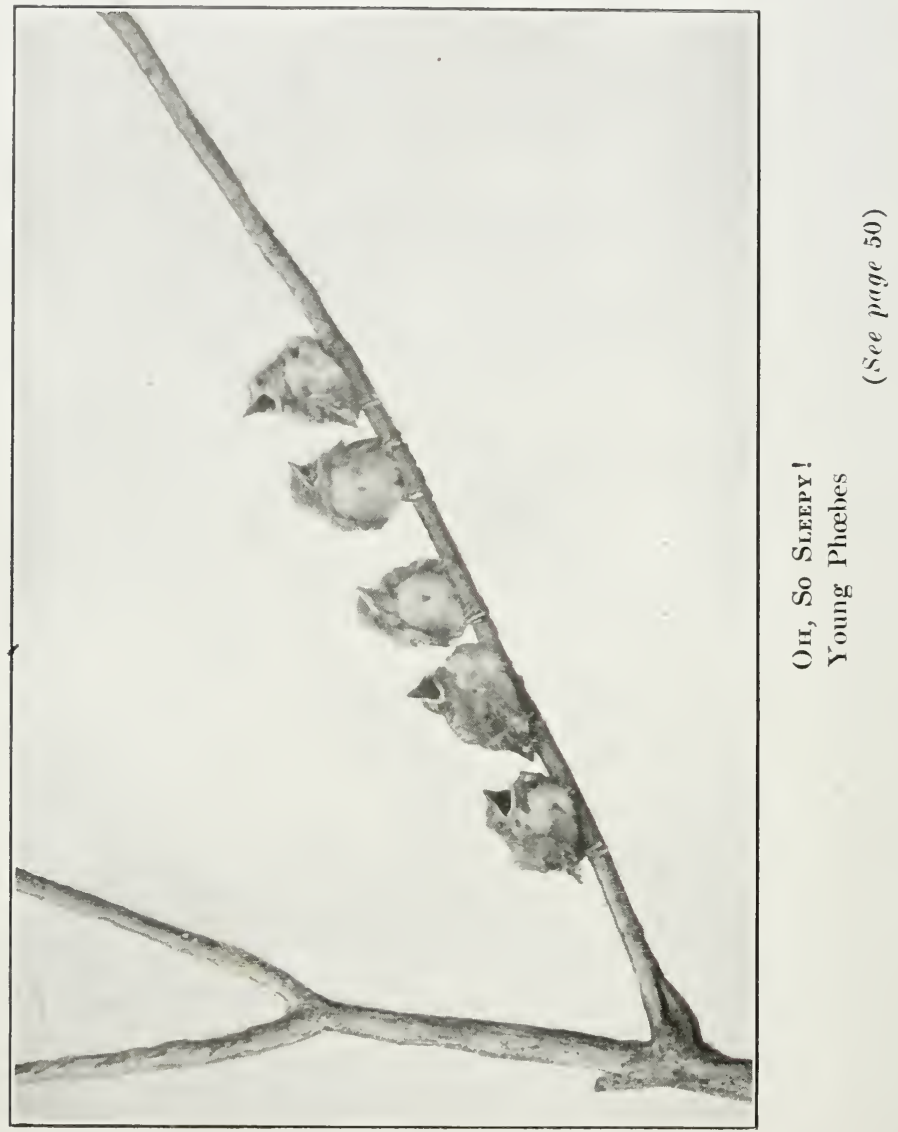




\section{Bird Notes and their Value}

then, suddenly rising - their crest-feathers standing up stiff and straight and their long heads and necks and beaks stretched forward as far as possible as if in alarmthey mount above the tree-tops and make a wide detour out over the meadows, coming back to the stream again at a point at some safe distance away.

The Kingfisher's colors are steel-blue and white. He is short of body and wide of wing-averaging about twelve inches one way and twenty-four the other; and the mark from which he takes the forepart of his title is a narrow band of dark gray across the upper portion of his broad white breast.

When ready for nesting he digs a round hole four inches or so in diameter in the side of some clayey bank and about a yard below the surface, excavating to the depth of about six or seven feet, and enlarging it to quite a commodious cavity at the end-in which he fixes up for himself a very comfortable retreat of dried grasses and feathers. 


\section{A Book on Birds}

The Kingfisher is well named, for he generally has in fact a royal time of it when he turns to the piscatorial duties of his daily routine. Sometimes he dives into the water after his prey in the very course of a long, swift flight close to its surface; at others, he makes his plunge from a favorable perch at the end of a broken log projecting beyond the bank; but, whatever the method, he is an adept at the business and rarely fails to get what he goes after; nor does he often neglect to let out his rattling cry, as he emerges dripping wet, especially if the finny victim in his clutch be a big one; and it seems to me on these occasions to have a rollicking note of exultation in it, instead of alarm. 

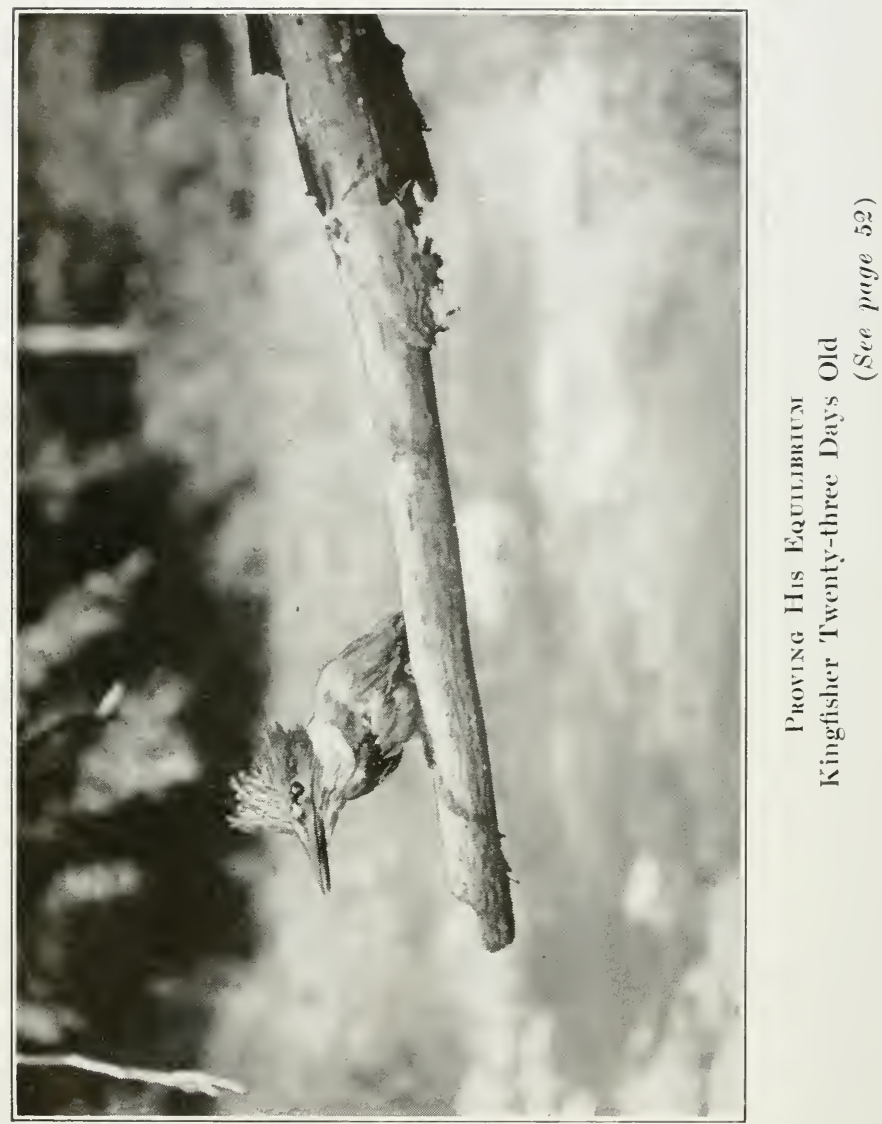


\section{My Morning Minstrel}

My Morning Minstrel

In sackcloth clad, from hill and plain, The day advances, bathed in tears; But music stirs my sluggish ears,A Robin singing in the rain!

I rise, and in the dull gray light I see him from my window-seat, The leafless branches 'neath his feet Half hid by lingering mists of night.

Against his draggled front, forlorn,

The chill March breezes moan and sigh;

But still, with head uplifted high, He carols bravely to the morn.

Then I who listen feel a glow-

A quick thanksgiving-touch my heart;

The veil is rent, the mists depart, Again the vernal zephyrs blow.

While, with the song, from everywhere, A sudden flush of spring descends, And, even as the singer ends, Sweet breath of blossoms fills the air.

O happy-throated minstrel mine,

I bless the dawn that gave thee birth, And set the tenderest chord of earth Within that sturdy breast of thine! 


\section{Chapter IV}

IN THE WAKE OF THE BROWN THRASHER

THE finest woodland singer of the first real days of spring in my neighborhood, and the one most lavish with his splendid store of song is undoubtedly the Brown Thrasher-the "Thrush" that is not a Thrush at all, but a species of Mocking-bird.

And he is a wise singer, too,- - his habit of ignoring the deceptive lures of the vernal equinox and delaying his arrival until the white cherry-blossoms have in fact appeared, and fill the thicket with their fragrance, and the clusters of the spicewood warm and brighten it with gold, adding not a little to the witchery of his wonderful voice.

He may be expected with almost absolute certainty by the twentieth of April where I live, along with the Chimney Swift and the Wren; but scarcely an hour before that. 


\section{In the Wake of the Brown Thrasher}

Then, however, and for several weeks after, you may start out any sunlit day and be sure of finding him and hearing him hold forth for you at length and unafraid; provided, nevertheless, you go before ten o'clock, if in the morning, or not earlier than four, if your trip be taken in the afternoon.

And it is quite probable he will make himself known while you are yet afar off; for his notes have the clear quality that gives them carrying power.

Selecting a branch so located that there shall be naught between him and the slanting or level light from the east or west, he pours forth a rich and varied strain that loses little even by comparison with that of his more aristocratic cousin of the South-a strain which contains for him such ecstasy of delight that he overlooks your approach until you are so near you can discern the brilliant yellow of his eyes, the surge of his mottled breast and the opening and closing of his long and slender beak. 


\section{A Book on Birds}

Even when he sees you, and, alarmed by the crackling of a twig or some sudden and abrupt move you make as you draw closer, flies off to a new perch, he is likely to pick one but a short distance away and keep on singing as he goes, unwilling to check but for the moment or two of his flight the lovely tide of melody within him.

Moreover, the advent of the Thrasher is notable also for other reasons beside the pleasure there is in it of itself. It is a sure sign that things long delayed have finally come to pass; that violets may be looked for among the dead swamp grass and briars; that the delicate anemone, some of it pale pink and some pearl white, is abloom in the leafy mold beneath the oak trees, and the spring beauty farther on above the dewy moss along the banks of the stream; and, last, but not least, that the best and most prolific time for the discovery and observation of birds in this part of the country is immediately at hand.

For, though it will seem otherwise to the uninitiated, the month of June, when the 
In the Wake of the Brown Thrasher

year has reached its full flood, will never be found quite so rich in results as the first two or three weeks in May; and this for a special reason with which all ornithologists are well acquainted.

In considering opportunities for seeing as many specimens as possible, birds divide themselves into two general classes-those that nest and make their home in our own fields and forests, and those that are merely migratory visitors. And we should never forget that these latter must be looked for while they are passing and loitering on the way, or most of us will never have the chance to find and study them at all.

It is because of this fact that the day of the coming of our friend the Thrasher is especially interesting. His clear, sweet voice leads on not only the great multitude of those that remain with us all summer, but the multitude of birds of passage as well, including the wonderful little Wood Warblers (these alone numbering some twenty-five kinds) and many others beside; 


\section{A Book on Birds}

all of whom may be searched out and identified one by one to your delight, from the day you first see him.

Therefore, now, if ever, sally forth upon your questing. For just now the home birds that await you-increased by new arrivals every day-will be found in company almost everywhere with the migrants, these displaying many exquisite charms of brilliant plumage and voice that even the others we love so well do not possess.

It is true, indeed, that some few of the transient visitors reach us much earlier than the Thrasher and have already proceeded northward. Among this number is the Fox Sparrow-a bird every lover of birds should know. He is quite the largest of the nine different members of his clan with whom I am familiar, and he is pretty certain to reveal himself, before your eyes detect him, by his ever-recurring and wonderfully bright and warbling note, which has a gentle tremolo in it, put there possibly by the impulse of his short, quick, restless flights from limb to limb. 


\section{In the Wake of the Brown Thrasher}

Let us look him up a bit. It is early morning, clear but cool, and the trees are still leafless. You have caught the mysterious lure of his voice (coming from everywhere and nowhere, like that of the Bluebird), and he has companions with him to the number of a dozen or so; and yet you find it impossible to fix any of them longer than an instant, so shy and elusive are they; until at last one actually does sit quiet with his back toward you on the gray and white branch of a buttonwood tree.

Then you find through your field-glass that his feathers are streaked slate color from the crown of his head to his rump, and that here they change with absolute abruptness to a strange cinnamon-brown down to the end of his tail. He is almost as large as the Hermit Thrush and his white breast is conspicuously marked with many rich brown blotches.

Up in Canada, where he spends the summer, his music-which with us is but a thrillingly sweet hint of a real song- 


\section{A Book on Birds}

develops, it is said, into strains of considerable length and rare and entrancing beauty.

Close in the wake of the Thrasher every spring comes the exceptional and eccentric Chimney Swift-a bird we see by the thousand at a distance and yet know far less of than we imagine.

By many he is called a Swallow; but mistakenly, as he belongs to an entirely different family of which, by the way, he is the only representative in our climate.

Those who have never observed him close at hand, but entirely on the wing, in his wonderfully rapid and circling flight through the sky (for he is hardly ever known to alight on a tree-or anything else, for that matter, than the inside of a chimney) have no idea what an oddlooking specimen he is.

His head is almost as flat as that of a catfish, his beak is so stubby it is scarcely any beak at all; his mouth is broad and large, and what face he has is ridiculously short, with a fullness on either side that 


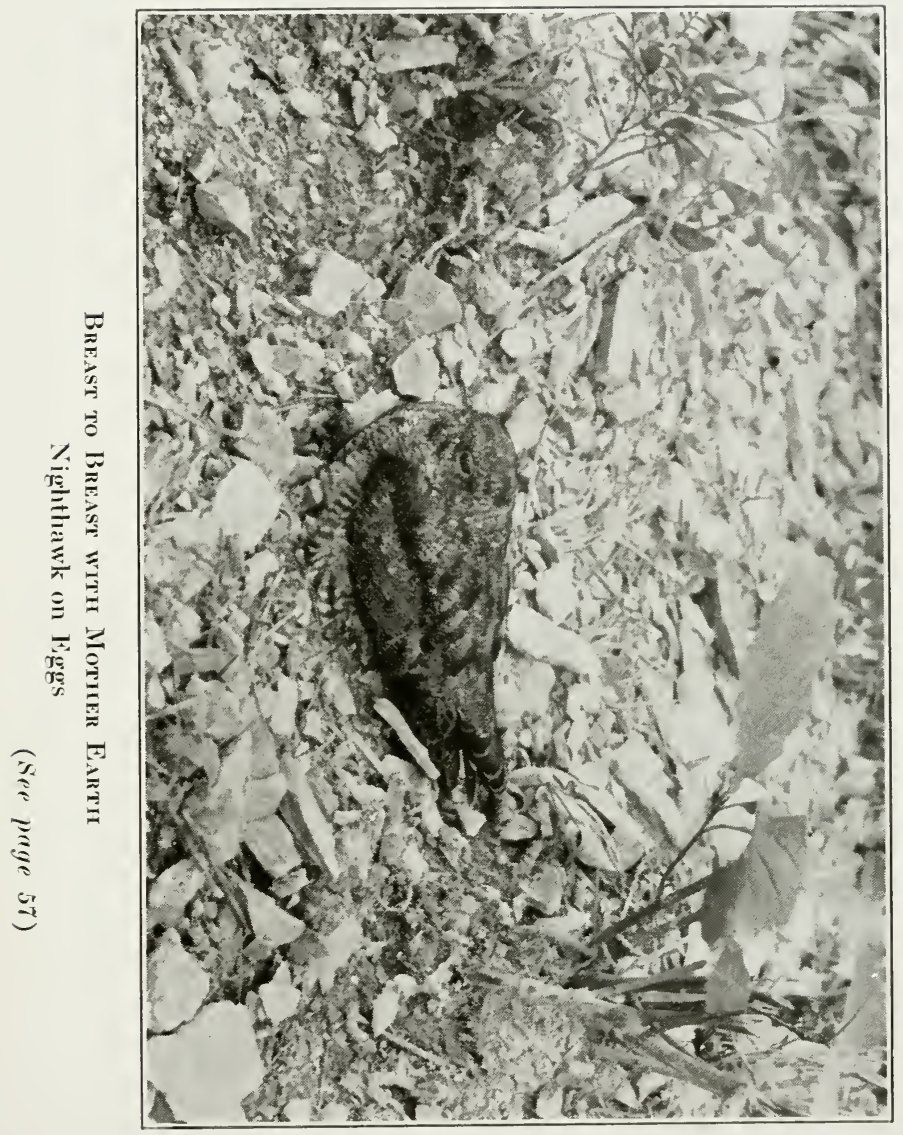



is at once suggestive of the jolly, round cheeks of a Brownie.

His body is so abbreviated and his pinions are so long that when cleaving the air (and no bird under heaven delights more to do this nor has a merrier, livelier time at it than he), this rollicking little fellow of lightning speed looks not unlike a large wishbone on the wing.

And who has not watched with fascinated interest his bewildering capers in the sky? Twittering incessantly as he goes, he seems the very abandon of free and joyous motion -never tiring, nor relaxing for rest, but apparently bent each new moment on some bolder and more startling tangent than any undertaken before.

He even does all his eating on the wing, so that his gyrations are not entirely for pure sport after all; and-what is really remarkable-he actually snaps off while in flight the small, dead twigs of trees which he uses in the construction of his nest. This, in turn, is most strangely made and quite as unique as the bird 


\section{A Book on Birds}

himself, the twigs composing it being shied together by him like wicker-work with a gelatinous substance, secreted in his mouth, and fastened rudely, without any lining of grass or feathers, against the inside of the chimney-somewhat as a semi-circular fungus to the bark of a tree.

In earlier times the Swift made his home in caves and hollow trunks of the forest, and resorted to chimneys when these appeared because, probably, like many other birds, he is of a social disposition and seeks proximity to human habitations; and for the further reason, no doubt, that he found as caves and hollow trunks grew fewer with the march of civilization, the number of large, well-warmed and easily accessible chimneys continually increased.

One of the most entertaining sights imaginable is to watch a flock of Swifts at evening in early autumn, circling some one of these towering piles of brick or stone for an hour or so after sunset, in a wild, merrygo-round flight, and finally pouring down into it in a great stream. 


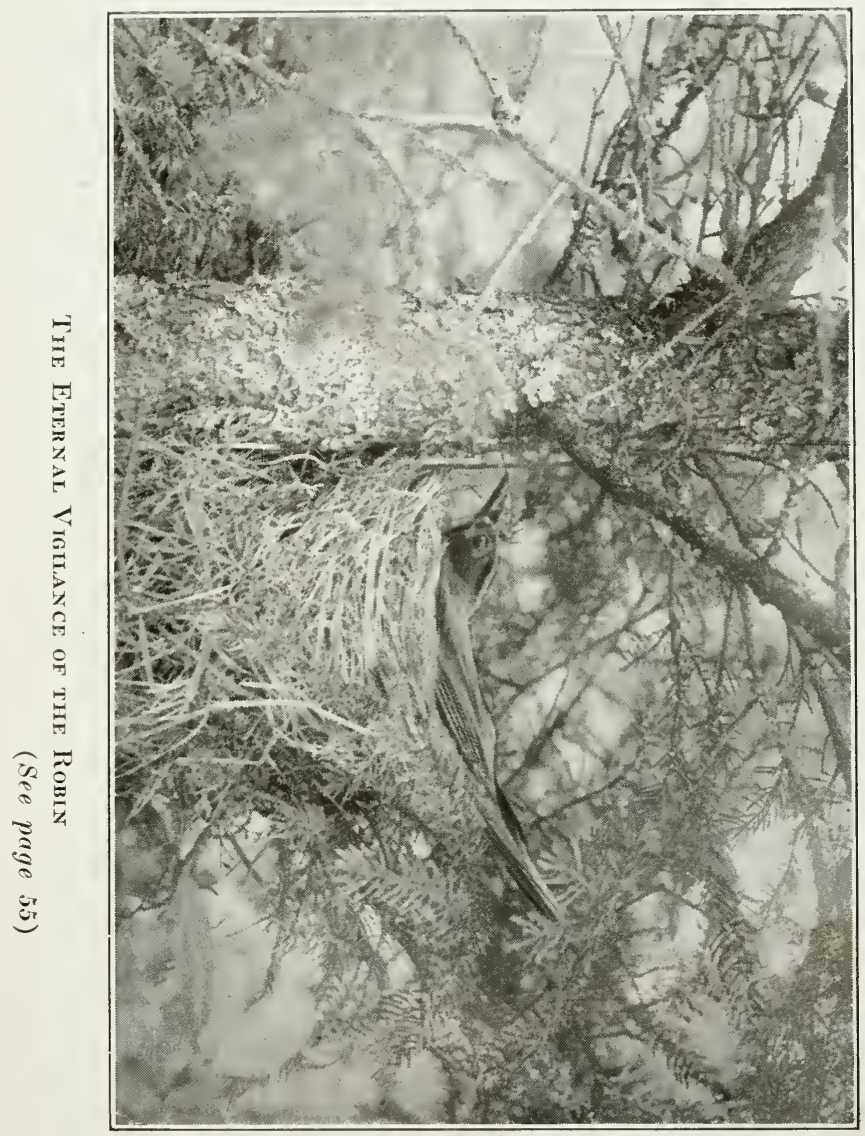





\section{In the Wake of the Brown Thrasher}

Some years ago two or three hundred of them indulged in this performance nearly every clear night during the month of September at All Saints' church, near my home in Norristown, Pennsylvania, much to the astonishment and delight of a number of small folk to whom it was entirely novel, and who turned out regularly to see it. The chimney here is capacious, or there would not have been room for them all.

They go inside to find shelter and sleep, of course, clinging close together along the interior until sometimes it is lined completely, and getting additional support for themselves from the stiff spikes or spines with which they are provided for that purpose in place of a tail.

The circumstance that Chimney Swifts feed entirely on insects, which they take while in flight (and they are able to do this at night as well as during the day time), results in season in their becoming indirectly a sort of natural barometer. When prevailing clear weather is to continue, the bugs they relish fly high in the buoyant 


\section{A Book on Birds}

atmosphere; and so must they to get them. While a heavy, moist air pulls both down close to the surface of the earth. And who has not seen this? The birds soaring at times in a bright, blue sky so far aloft they were almost invisible; and, again, on a changeful day sweeping by so low as to just graze the tops of the fences.

The Chimney Swift is very softly and closely feathered, and in color is an ashenblack above, and a pearl-gray upon throat and upper breast.

What becomes of him in winter has been a much-mooted question among ornithologists, some of whom, after repeated unsuccessful efforts to find the terminus of his annual migration southward, declare that he seems to literally disappear from the face of the earth during the entire time cold weather prevails. Whether this means that he hibernates somewhat after the habit of snakes and bats; or, as is more likely, seeks some congenial bourne thus far unknown to us, is a matter still to be exactly determined. 


\section{In the Wake of the Brown Thrasher}

Another bird whose annual reappearance is suggested by the Swift because he is equally eccentric, is the Night-hawk. He, too, may be seen quite easily in summer, for he feeds in very much the same way and has a habit of doing it at evening also, and immediately over a town or city. His head bears a marked resemblance in shape, particularly about the thin, wide mouth, to the head of a frog, and some of his habits are very odd indeed. He builds no nest at all, but his two darkly-spotted, oblong eggs are laid directly on the ground-usually on the side of some small hill, bare of grass, at the stoniest and most unprotected place he can find.

If you should discover them-and it is hard to do so, because they blend with their surroundings - he will occasionally take them in his mouth one at a time, at the first opportunity afterward, and deposit them at some new point a little distance away, where you will not be likely to come across them again.

The Night-hawk is nearly the size of a 


\section{A Book on Birds}

small Blackbird; is dark in hue and finely speckled; and has a conspicuous white patch about the middle of each wing which looks like a hole when he is flying.

He may be identified at once during the first half-hour of twilight by the way he rises in the air in short, quick flights, uttering a piping cry with each, and, having reached an altitude satisfactory to his taste, dives down, either in sport or to capture some gnat he has sighted below - the air rushing through his bristling wings and making a hollow noise as he goes, like that produced by blowing into the open mouth of a bottle.

The sharp contrast between birds like the Night-hawk and the Chimney Swift, who somehow seem unpleasantly transformed as if by the smoke and grime of centers of human habitation, and all the others, like the Thrasher, who suggest nothing but the freshness and beauty of nature, just as it was at the beginning, is always apparent; and it stirs an instant, deeper longing for orchard and meadow and rip- 
In the Wake of the Brown Thrasher

pling brook, and wooded slope, and the boundless firmament, where the myriads a-wing that have never gotten beyond these native elements for which alone they are so evidently made, are joyfully assembling as I write. 


\section{A Book on Birds}

\section{The Boy of the By-WaY}

One April morning, as I went To work, depressed and uncontent.

I met a lad who made me glad

In a trice with some odd tricks he had.

The air was cool and brightly clear, And he cried, the moment I drew near, "Oh, uncle, say-isn't this a day?Turn off that street and come my way!"

"It's farther, I know, thro' the fields, but yet You're early-and think of the fun you'll get!" And he coaxed-and still he coaxed, until I said at last "I believe I will!"

So over a fence we leaped and then Ran down a hill and up again; Then wheeled about and shouted out, And looked back over our rambling route.

Then he did a handspring, and then a lot Of other stunts I had half forgot; And he stoned a mark, and whispered, "HarkWhile I whistle a bit and lure that Lark!"

And the more he did the better I felt, And the sweeter the vernal breezes smelt; Till, at last, when he sang till the echoes rang, I tingled clean thro' with his own wild tang. 


\section{The Boy of the By-Way}

And I vowed to myself I had never seen

The sky so blue or the grass so green;

Nor everywhere the earth so fair

And utterly free from pain and care!

And, feeling thus, when we came to part,

I thought, "Here's a youngster I've liked from the start,

And henceforth-egad!-when I'm sour and sad 'Twill be well to remember this same lad."

So I called, as he vanished from sight, "Old man, Let us meet some day again, if you can!" "Sure! count on me"-with a laugh said he, "For I'm simply the boy you used to be!" 


\section{Chapter V}

\section{RAINY WEATHER AND WRENS}

THE "bad days" that so frequently interrupt the vernal tide during April and early May in our climate, checking it with the chill of winter, are after all of no mean value because of the way they accentuate by contrast the glory of the others. Indeed, I have sometimes thought that with fewer of them spring might even grow monotonous. It would at least fail to stir within us that peculiar sense of appreciative joy we inevitably feel upon the sunlit morning-fresh, fragrant, blossomy-which sooner or later is sure to follow what we counted perhaps a disastrous spell of unseasonable weather.

Furthermore, the abundant rains produce a wealth of foliage and vegetation which, of course, would otherwise be lacking.

My attention was particularly attracted 


\section{Rainy Weather and Wrens}

to this latter fact during several years (in every one of which long stretches of these "bad days"-with peerlessly beautiful breaks in them-were the prevailing order well on toward June) whenever I went forth from my home to a desolate tract of land, not far away, which but recently before had been the site of a noble wood. I found here that the incessant showers helped things in a marvelous manner, hiding rapidly under their influence beneath many a leafy covert the grievous hurt that had been done in leveling the great trees to make way for the extension and development of the town.

Bushes, vines and saplings soon sprang into profuse growth on all sides. And then the birds came, as to few places elsewhere, and helped along not a little, singing daily the wraiths of the trees as it were into deep forgetfulness.

And it happened somehow that, in the whole throng of them, I learned to love the Wrens best. This may have been, I admit, because of previous prejudice in 


\section{A Book on Birds}

their favor; for they have a universal way of getting near to the heart of man.

But in any event at this place their cheery talk invariably appeared to invite and attract me first.

Of course I encountered only one species - the House Wren; and who does not know it almost as well as he knows himself?

For, as his name suggests, he delights in human companionship, this trait of his being so pronounced that he is liable to settle down and build his nest in almost any place at all associated with the habitations or haunts of men.

I remember once finding one of these little fellows-after searching high and low in vain for a half hour, lured on by his excited chatter-most comfortably ensconced for the summer, with his tiny brood of seven, in the recesses of an old boot caught tight fast in the branching forks of a big apple tree at the rear door of a farmhouse up in the country-the very last nook in the whole neighborhood where I had thought of looking. 


\section{Rainy Weather and Wrens}

Following his usual methods he had filled the boot chock-full of clean, dry grass, lined with soft white feathers; and as the top of it pointed downward a trifle, he and his family were just as well sheltered in it from the rain as in the holes in trees and boxes to which they ordinarily resort.

The House Wren is so small (his actual length of body not much exceeding two inches, as a rule, exclusive of beak and tail) that one of the most remarkable things about him is the amount of noise he makes - and this, too, notwithstanding the fact he seems to have an impediment in his speech.

He sings incessantly, his strain always starting with an amount of splutter and stammering that seems to give him a whole lot of trouble, before he finally breaks through into the whirling little cadenza of true melody with which he brings it to a close.

His back and head are brown and his breast is of dull gray; but the marks by which he may be most easily identified 


\section{A Book on Birds}

(excepting always his diminutive size and peculiar "spiral" music) are his narrow beak and short, straight tail-feathers, tilted upward at an angle that grows sharper as you approach more closely to his nest.

No bird can be studied with less trouble than he, for he will allow you to get as near to him as any I know. And no opportunity for meeting him on every hand could possibly be better than that still offered by this overgrown tract near my own town.

Next to the Wrens in this same locality I found the Brown Thrasher the most interesting.

In the morning before eight o'clock, once I had reached the bushes and saplings, I generally heard his music coming from three or four directions at once.

And I never failed to stop and listen a little in enrapt silence.

For, as we have said in the preceding chapter, it is music well worth whilethough only those who hear it in its first freshness in the spring know it to the full. 


\section{Rainy Weather and Wrens}

Then, however, I think it nearly on a par with that of his kinsfolk, the Wood Thrush or the Hermit-the latter rated by many the most melodious in nature.

In support of this opinion I may mention the case of a friend who, though a true naturalist by instinct and education, came to me once and declared he had heard a Southern Mocking-bird singing in the wood near his home the previous morning.

When I suggested that this one must have lost his bearings completely to stray so far up into Pennsylvania-and so early in the season, too-he met my doubt by saying that he would try to find it again and examine it through his field-glass; the result being that he reported a day or two later that his "Southern Mocking-bird" was simply a Brown Thrasher (as I suspected), whose wonderful vocal powers were a genuine revelation to him.

And so they will be to you-if you approach his choir-loft (usually the topmost branch of a small tree where he can feel the early sunshine full upon his face) 


\section{A Book on Birds}

with "light and airy tread," until you are very near; and then keep quiet long enough to hear his performance to the end.

You will have no trouble in discovering him-for he is a big bird (larger than the Robin), his back and tail being of reddish, rusty brown, the tail-feathers very long.

Moreover, in this quest for the Thrasher you will by this time of the year be likely to meet many delightful diversions on every side.

At almost the same point where I used to hear the Thrashers a Flicker had his home in a hole about eight feet from the ground in an old wreck of a tree.

As often as I came there with friends and knocked just below with a stick or a stone he would come out very promptly to find who it might be.

Whereupon, if these friends had not met him before, they were always taken aback with surprise at his appearance; for a fullfledged Flicker is a "sight to see," being "dressed to kill" in a lot of gaudy and superfluous finery, stuck on haphazard, 


\section{Rainy Weather and Wrens}

like that of a proud and very ancient old maid.

His fixings are of six or seven colors, some of which "clash" badly - the most conspicuous being the bluish-gray and faded pink about his throat, the great patch of scarlet at the nape of the neck, and the flaming yellow of the under parts of the wings.

In this fondness for gay apparel the male and female Flickers are almost exactly alike, being in this an exception to the rule among birds, which is that the head of the family appropriates the brighter, showier tints all to himself, leaving only the dull and neutral shades as the humble portion of his mate.

In flight also the Flicker differs markedly from most birds, going up and down, with a wave motion, like the little American Goldfinch.

And finally he is even more exceptional in one other particular. His behavior in the mating season when making overtures to the lady of his choice is one of the most 


\section{A Book on Birds}

laughable spectacles in nature. Love seems to set him daft completely, his idiotic tendencies under its influence showing themselves chiefly in a most remarkable stretching and twisting of his long neck, with many outlandish movements in every possible direction, whenever sitting near his fiancée-the insanity of it all quickly communicating itself to her with similar results. Two boys whom I once called to watch a pair thus affected, and perched about a yard apart on the branch of a cherry tree, declared in astonishment that they acted as though they had been drinking. But I told them it was intoxication of another kind. 


\section{My First Bobolink}

\section{My First Bobolink}

At mid-morning yesterday, up in the hills

I met a strange bird with such wonderful trills

And magical blending of music and noise,

(Like the composite voice of a group of small boys,

Or perhaps, better still, like a half-dozen girls, Some chatting, some singing, in eddies and whirls

Of small talk and melody, all in a mix),

He stopped and dumfounded me quite with his tricks.

Now who can he be, thought I, thus to pour forth Such warm southern ecstasy here in the north?

He's new to me surely-yet surely I've read Somewhere of those black and white wings, and that head

Tilted upward so pert, with its saucy buff capSo far back and so small that the slightest mishap

Might, methought, jar it off in a trice to the ground$\mathrm{Oh}$, who is this very bird-Babel of sound?

Thus I questioned in wonder-yet not lacking delight,

As, with all its confusion, his voice charmed me quite:

For the sunshine was in't-when the plashing of rain Of a sweet April day-then the sunshine again; 


\section{A Book on Birds}

But, most, the great gladness of spring at the flood, The quickening gladness one feels in the blood.

So, nearer and nearer I drew, loth to go Unacquaint with my minstrel, still singing; when, lo, (Mirabile dictu!) the bird seemed to talk, Saying, "How-dy-do, friend!-you are out for a walk "And can't guess who I am-that is easy to trace From the puzzled expression all over your face.

"I'm a little far north, I'll admit; just the same A field-lover, like you, should at once know my name. "Here's a strain with a somersault in it, or two, Pray, tell me, sir, don't that suggest it to you?"Or this, with a movement so much to my taste I sing it both backward and forward, nor waste

"A note or a syllable doing it-see?

There-I've mentioned my name, and you missed it-ah me!

"But I'll give you just one warble more, while you think;-

Ho, you've hit it at last!-au revoir!-Bobolink!" 


\section{Chapter VI}

THE WOOD WARBLERS

7 the newly initiated, seeking a knowlwide expanse of territory, already designated, which takes in my own stamping-ground (and which, to be more exact this time, extends from the middle counties of Pennsylvania to the upper boundaries of Maryland and runs across into New England on the one side and to the Mississippi on the other) the fact of the existence of the large and brilliant feathered family styled "Wood Warblers" is always sure to come at first with a deeply fascinating surprise and interest.

For it seems almost unbelievable for a while that these charming little wingéd beauties should appear and depart year after year, in great number and varietyand yet the mass of people not be acquainted with them, or, indeed, even see them at all. 


\section{A Book on Birds}

The circumstance is attributable of course to their diminutive size, their extremely quiet and retiring habits, and the fact that most of them do not nest here-but farther north, even unto Canada and Labrador and the land of Evangeline.

But notwithstanding this, our lack of knowledge is still remarkable-for in migrating they are with us sometimes as long as three or four weeks, both spring and fall, and most of them are so wonderfully bright of color that they are nothing less than an embodied joy to behold.

There are probably as many as twentyfive species that pass our way, in these silent, semi-annual flights of theirs; and upon clear days, as the sunlight discloses them amidst the foliage, they flash and sparkle like precious stones-in their incomparable hues of carmine and gold, sapphire and emerald, brown and ebony, orange and white.

In all this shining galaxy the Maryland Yellow-throat, the American Redstart, the Yellow-breasted Chat and the Golden[84] 



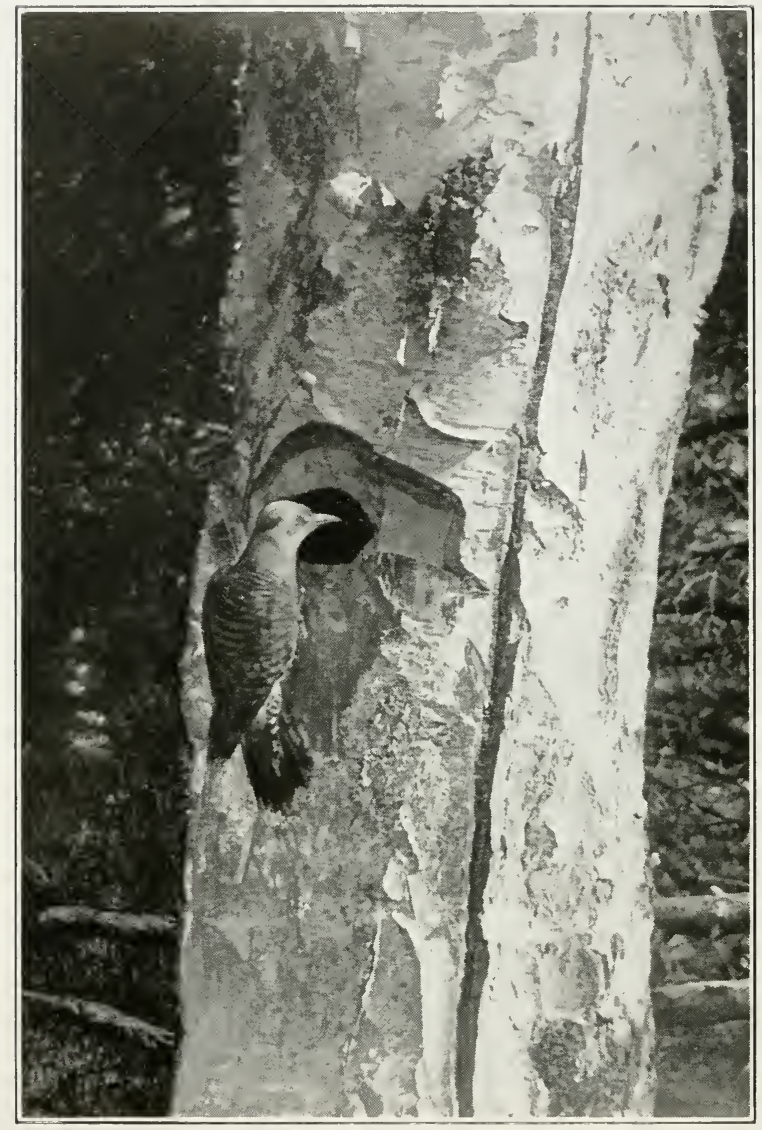

At His Ever Opex Door

The Flicker

(See page 78) 


\section{The Wood Warblers}

crowned Thrush (styled also the Ovenbird, from the peculiar shape of his nest, as well as the "Teacher," from the resemblance his music bears to this word, pronounced quickly a half dozen times and with varying accent), and the Yellow Warbler, are most numerous and familiar because many of these build here.

But one other I have found very conspicuous in the wooded haunts I know; first, by reason of his solitary arrival about the beginning of April, before all the rest; and, second, because his contrasts of color (at least, as I have seen him, for birdplumage is sometimes a very changeable quantity) are so great as to make him exceptional even among Wood Warblers.

I refer to the Palm Warbler-a delightful bird to me, and most friendly, approachable, and charming to behold hopping about quietly over the thickly-spread brown leaves and through the naked branches, in his lovely habiliments of yellow striped with rich brown, below, and dusky olive above, with touches of pure white here 


\section{A Book on Birds}

and there in wings and tail, and the bright, distinctive crown (too chestnut in tint to be red, and yet too red to be chestnut) which covers the entire top of his graceful little poll and is so warmly beautiful that one's pulses quicken a bit every time a vernal sunbeam finds it.

Would that every beginner might first discover him as I did, with Hermit Thrushes to keep him company and make the morning glad!

If, however, you start forth into the country at the season in which I am now writing, do not expect him.

It is well on in May and he has probably been gone for almost a month.

At present I think you will be far more likely to meet at once the Maryland Yellowthroat instead.

And suppose you really do start and see!

Unless he has changed his habits, he has been disporting himself for some time in these thickets, and the leafy, tangled underbrush just over the fence, across the road. 


\section{The Wood Warblers}

And you will almost certainly hear him before he reveals himself. For his note is loud for so small a bird, though not by any means unmusical; and, beside this, it is so striking in its repetition that it will not fail to attract your attention instantly. It sounds to me, for reasons hereinbefore stated, very like the name Jessica, reiterated four times rapidly and in a high keyhaving in it the distinct inflection of voice of a little child calling in a tone of tearful alarm and distress.

But when at last you find him, your eyes will quicken to a vision of rare beauty; for "Solomon in all his glory, was not arrayed like one of these." And that you may judge of this the better here is his "color scheme": Back-olive green; chin, throat, breast, undercoverts and edge of wings-bright yellow, fading into a soft buff white; forehead, and a broad band upon sides of neck-pure black, bordered with gray; wings and tail glossed with yellowish olive.

But, bright a picture as he makes, there 


\section{A Book on Birds}

are other Wood Warblers, and many of them, even brighter than he. And Indian Creek (a stream, well known to Audubon, flowing into the Schuylkill river about two miles above Norristown) is of all localities within my own observation the place of places to find them. Here they linger in the spring until Memorial Day, feeding and flitting from twig to twig amidst the thick branches shot with sunlight that overhang the clear and rippling surface of the water. And it was among these little migrants that Audubon came upon his rarest and most beautiful "finds," along this very stream during those days a century ago when he found also his bride and made his home in the famous house by the Perkiomen, which still stands there in perfect preservation and good order.

As we think of this our quest becomes invested at once with a deeper, finer interest; the velvety moss seems richer beneath our tread, and the older forest trees which tower to the sky along the high, precipitous banks seem to tell faintly of 


\section{The Wood Warblers}

other, unforgotten footsteps; for Audubon was unquestionably the truest bird-lover of us all.

And if we have not thus far realized it in Pennsylvania as we should, there are nevertheless signs we are approaching gradually a full recognition of the fact.

Down in Louisiana, where he was born while the Revolution was still in progress, they have, at New Orleans, a magnificent park bearing his name, which, with its splendid Horticultural Hall filled with tropical trees and plants, and its model sugar and cotton farm fronting on the Mississippi, constitutes an adequate monument to this pioneer, who won kings for his patrons that they might help him bring to successful completion after many years a publication which has commanded the admiration of the world ever since.

And his position in the realm of natural history has been marked almost as well in New York and elsewhere. So that when we, of my own State, who have larger claim to him perhaps than any others, take steps 


\section{A Book on Birds}

in time to accord him further honor (as we no doubt will), what we do will be justified by many worthy precedents. Nor will we find local inspiration lacking entirely. The great naturalist's quaint but dignified old mansion up in Montgomery county has been nobly looked after for many years by a well-known family; and every ornithologist of the present generation who has ever made it his Mecca has returned thence with renewed zeal and enthusiasm.

However, this is parenthetical. Let us return to the Wood Warblers at Indian Creek, some of which Audubon first discovered here, painting them into his immortal series of more than a thousand specimens.

As we come, the American Redstart meets us directly, and almost before we are well amongst the trees. Think of a bird only about the size of your thumb in the brilliant garb of the Baltimore Oriole-and you have him; except that the flaming orange red, which is his dominant color, is sometimes even more splendid than the Oriole's. 


\section{The Wood Warblers}

But the Redstart is only the preliminary relish to a very feast of sights for those who press on through these dim-lit, winding aisles.

The Magnolia, the Myrtle, the Chestnutsided, the Parula and three or four other Warblers are here; and then beside these you may see or hear, if you stay long enough, the Wood Pewee, the Crested Flycatcher, the Yellow-billed Cuckoo, the Kingbird, the Turtle Dove, the Red-eyed Vireo, and the White-breasted Swallow; and, perhaps, far outside in the meadows somewhere-a few noisy, rollicking Bobolinks.

For June, with her roses, is not far away; the Goldfinches, after a whole month spent among us in light-hearted idleness and dissipation, have begun to think of nesting; the Ruby-throated Humming-bird may be looked for soon; and they who glory in God's open air will ere long have come again to their own full heritage. 


\section{A Book on Birds}

\section{The Hermit Thrush}

Sweet singer, in the high and holy place Of this dim-lit cathedral of the hills; With reverent brow and unuplifted face,

I quaff the cup thy melody distills.

What sparkling well of limpid music springs

Within thy breast, to quench my thirst like this! What nameless chords are hid beneath thy wings, That all my soul is quickened by thy bliss!

Perchance the same mysterious desire

Hath brought us both to this deep shrine as one; For now it burns a single flame of fire,

Dropped through the branches from the setting sun!

And as thou singest, lo, the voice is mine,

Each note a thought; each thought, a silent prayer,

Of joy, of peace-of ecstasy divine,

Poured forth upon the fragrant woodland air.

And I, who stand aloof, am not alone,

Here in these great cathedral aisles untrod;

$\mathrm{O}$, Hermit, thou has opened heaven, unknown,

And through thy song have I communed with God. 


\section{Chapter VII}

TANGLEWOOD LANE AND SKIPPACK CREEK

T $\mathrm{N}$ the rural borough of Collegeville, 1 only a short distance above my home and as dear to my heart as some typical New England town like Concord to that of an average Yankee, there is a sequestered road which, just about the time it had drifted back finally to primeval nature even in the midst of civilization, was, strange to say, advanced in nomenclature to the proud dignity of "Fifth avenue."

It is a case which proves that with roads also, as with roses, there is nothing in a name. At least not very much. "Fifth avenue" it may be for a square or so, if you insist. But no farther. For, after that, it slips around a sharp turn; shakes off its ponderous, ill-fitting title with quick impatience; plunges down a rocky hill, just grazing a fine little patch of forest 


\section{A Book on Birds}

trees, and becomes in another moment the very "Tanglewood lane" of my boyhood days; except that it seems even more tangled and woodsy than ever.

Of course this village street which strays so easily into wilding oblivion is still in some measure (let us say to the extent of two farm wagons a week) a traveled thoroughfare; it being in fact the first real cross-road you meet to the right, going northward through the town. Yet permit it to lead you but two hundred paces toward the river and you will find, as I have stated, that it is not at all what it is paraded to be, but something vastly more delightful; provided, of course, the season be propitious, and you a lover of nature.

I myself have had a special affection for it as long as I can remember; an affection which has not diminished by any means as with each succeeding summer, because of encroaching growths of bush and briar and sapling on either siue, and grape and honeysuckle overhead, it has become more and more attractive to birds. 


\section{Tanglewood Lane and Skippack Creek}

Its devious, vagrant course covers hardly half a mile, all told, to the point where it ends abruptly on the high, steep bank of the Perkiomen. Yet, with these great masses of fragrant foliage which it accumulates by the middle of May for our wingéd friends of earth and air, it is a widely sought and ample rendezvous of theirs from then on until October.

But, now that I have said this much, let us stop off on our way thither to-day and thus not only prolong your pleasure of anticipation with regard to it, but reap other pleasure beside.

And, suiting the action to the word, how could we do better than turn aside just where we are this minute and loiter along Skippack creek a little, ere the sun goes down? There is a passage-way open right here, between the end of the bridge wall and the fence that does not quite meet it; and, going through, we are in a most birdlike atmosphere at once.

June is so near you can feel her immediate advent. The dark, mossy turf is bright 


\section{A Book on Birds}

with spring beauties and Quaker ladies and white violets; the great, tall trees (beeches, oaks, locusts, and sycamores) have gentle breezes in them that make beautiful play with the sunlight on the leaves; and the slope of the banks beneath goes straight down to the purling water and the quiet stone arch through which it flows.

Out beyond the trees there is a great meadow, well shut in; and here the grass is thick with buttercups and daisies and more Quaker ladies, beside many patches of the Star of Bethlehem, in its pure and lovely garb of green and white. The meadow is intersected by a tumbling wall, with a line of half-dead willows running through it; and the hills on the far side rise sharply and are well covered with other ancient trees, under which the perfume of sweet cicely ascends everywhere, like subtile incense through the overhanging branches; and the May apple, with its bloom in hiding, spreads like a deep, broad carpet; and the yellow of the wild mustard and the pale purple of the cranes- 


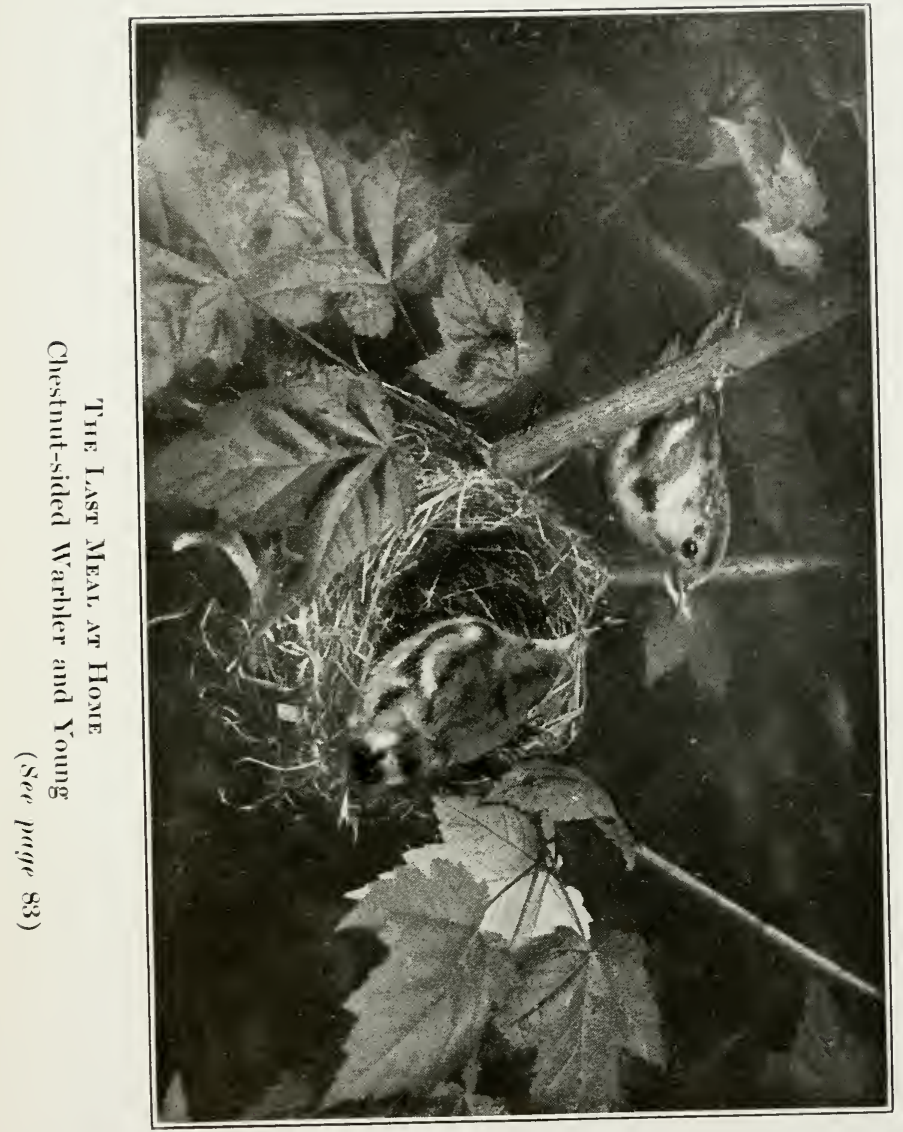





\section{Tanglewood Lane and Skippack Creek}

bill appear here and there and everywhere, enlivening the gloom.

But we have not arrived at the woods without many a pause as we came. And just because we have simply sauntered along silently, making these frequent halts by the way, and sitting down indeed at several points for nearly a half hour at a stretch, the birds have been most numerous, familiar and unafraid throughout the entire distance between.

How hard it is to adhere to correct methods of approach in anything! When the amateur ornithologist is wise enough to remember that the surest way to see birds is merely to pick out a comfortable place somewhere in the open and then wait in patience until they actually come to him-instead of thrashing about after them, with fuss and fume, he generally has his reward; for, after the lapse of only a comparatively short time, following this plan, the spot that seemed entirely deserted will as a rule show signs of life, if he but keep quite still; and eyes, and wings, and voices 


\section{A Book on Birds}

he wist not of will begin to manifest themselves.

Thus do we find it this afternoon. First we hear the stealthy "chuck, chuck!" of Wood Thrushes; then the two, high, noisy notes of the Kingfisher, which, mingling with those of the Blue Jay, seem very like them to-day; then the creaky little voice of the Downy Woodpecker. And then we not only hear sounds but commence to "see things"; and, behold, the emptiness is peopled with our friends!

From under the bridge come two Phœebes; immediately overhead the smooth gray figure of a Catbird emerges from the faintly rustling foliage, the big spot of mahoganybrown showing plain beneath the long tailfeathers; over the tulip tree, right beyond the fence a Kingbird hovers in that quick, nervous flight of his resembling exactly his piercing note, and both of them in direct contrast with the quiet movements and voice of his crested cousin, who alights on a limb below. Then the sleek, well-groomed Yellow-billed Cuckoo; and the Baltimore 


\section{Tanglewood Lane and Skippack Creek}

Oriole and his mate, both singing about the same notes; and the dowdy Flicker; and the Meadow Lark, with his black breastplate, one by one, show themselves, most of them drawing nearer and nearer, by easy stages.

How perfectly simple it all seems, compared with some experiences we have had, when, after long and tiresome walking, up hill and down dale, we returned halfdisgusted, having seen and heard practically no feathered folk worth speaking of!

Yet, come, come!- what of "Tanglewood lane"? We have started forward, and after fifteen minutes' stiff climbing have gained the rim of the woods, where we find we have just about enough time left to reach our Collegeville haunt by sunset-a most auspicious moment. So, through the fence we go again and up the turnpike!

And, stepping along, we quite naturally begin to recall some previous sunset experiences. For sunsets play a larger part in bird-questing than those who do not know may imagine. And they assume especial 


\section{A Book on Birds}

importance when they come in a burst of brightness to crown some dark and dismal day; having very much the same effect under such conditions upon bird-hearts as the hearts of men and women; dispelling their sadness and depression, filling them with song, and often conjuring suddenly out of absolute silence almost as much woodland music as the most roseate dawn.

Moreover, our brisk tramp-tramptramp-on the hard road-bed so quickens both memory and imagination that we recall in fact, on the instant as we proceed, at least one sunset of this very sort-a sunset many months previous above the Hundred-mile-woods in the verdant Chester valley.

As evening drew on it seemed that the storm which had prevailed during the afternoon was to have its unbroken will throughout the night. But just in the fulness of time every barrier of gloom gave way and the heavens triumphed gloriously.

Only a few brief moments remained for the victory when it came at length, and the 



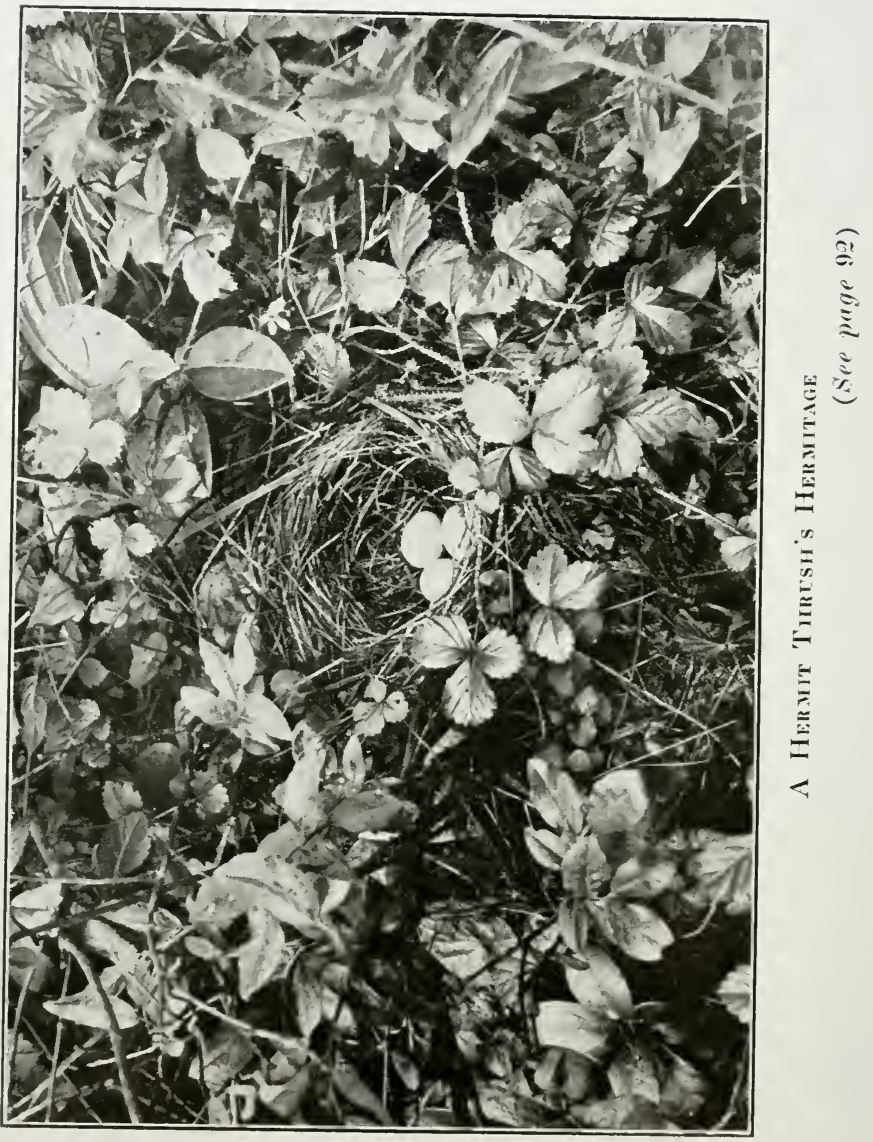




\section{Tanglewood Lane and Skippack Creek}

first bright banner of a royal host emerged in joy and flung its radiance afar; yet they were enough and to spare. For the chariots of the sun and all God's angels of light and color that lead them on are as swift as they are beautiful.

Aflame with gold, and violet, and crimson, of indescribable loveliness and many a baffling hue, they swept from the purple hills below and ascended toward the zenith.

In a twinkling the black and leaden cloud-waste of the sky blossomed to magnificent and rosy splendor-splendor heaped up mightily, mass upon luminous mass-splendor spread out through illimitable vistas, wave upon dazzling wave; like the land and sea of Paradise commingled and made one.

And then broad reaches of ethereal verdure, rare and delicate of tint as earliest leaves of spring, appeared upon the vast of this celestial scene and extended into space; while, floating toward the point of vision, as though they had escaped on either side from the rainbow chariots in their flight, 


\section{A Book on Birds}

little fleecy clusters, white as snow and shining like transparent silver, heightened all the deeper and dominant effulgence which held sway beneath them and beyond.

Thus-from shadowy river, and the meadows drenched with rain, and the lowering frown and menace of many wooded summits the sun withdrew with transcendent rejoicing; and yet almost as unnoticed of humanity in the silence as though its departure were at the very beginning of time and the earth itself still unpeopled. Except, perchance, that a home-bound toiler here and there looked up a little and was rested in his heart; or that some child paused in its evening play with wide and wondering eyes and was given, as it gazed, a vague, sweet sense of Eden and the gardens of the blest.

Except for this, and then, as I have said (and indeed in keeping with it), the universal stirring and singing which followed after, among the re-awakened birds.

But, behold! - "Fifth avenue" at last; and right around the corner "Tanglewood lane"!

[ 102 ] 



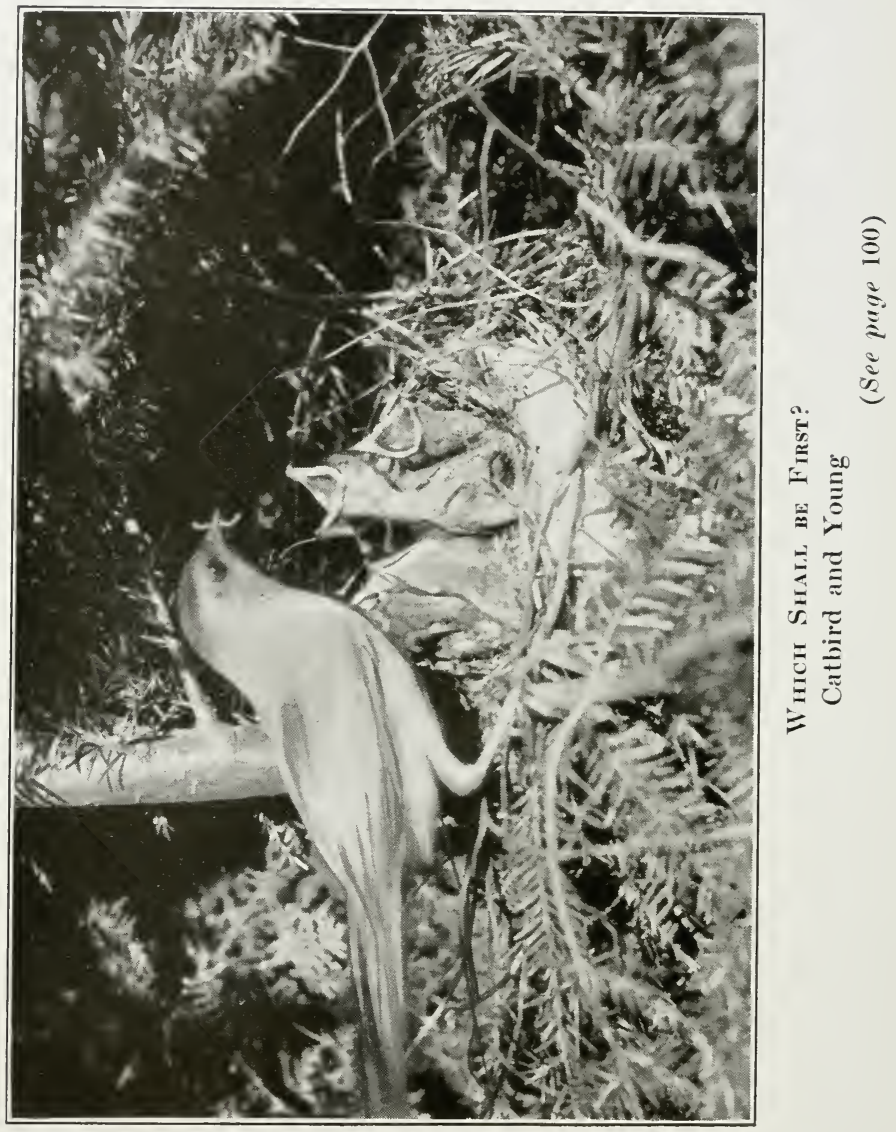




\section{Tanglewood Lane and Skippack Creek}

And here too, in truth, is the rocky hill; and so precipitous we must needs "put on the brakes" to keep from running as we descend; and here also the crumbling ruin of the old whitewashed stone house we boys thought haunted; passing which, we are once more brought to our old-time portal of the very heart of things.

For at this point a brook of sparkling water, coming through the trees to the right, crosses our path; and just beyond it, where the bank on the same side rises gradually to a height of fifteen feet and is covered thick with blackberry, there confronts our vision a narrow vernal labyrinth with a most alluring vista of leafy loveliness looking at us from the far end and inviting us to make the passage and take possession.

And now, as we respond and proceed, we realize immediately that the birds have truly gone before. In fact right over the gateway itself, where the rill runs by, and the branches are dense, and the level western sunlight creeps through but lazily, a Wood Thrush, sitting calm and stately 


\section{A Book on Birds}

on a broken willow limb extending above, slackens and silences our footsteps with his rich vesper song; nor takes his leave until we are almost underneath.

Then the Wild Dove (who for some reason is becoming a less familiar figure than formerly in these parts) cooes thrice and slips softly away to his nest of sticks and two white eggs back in the apple-orchard; and the Vesper Sparrow answers but holds his perch; and a Red-eyed Vireo actually comes nearer, sounding his rasping note; and then we see in succession a Crested Flycatcher; and a Chipping Sparrow; and a Song Sparrow, and a Yellow-billed Cuckoo, sad of voice; and a Catbird, in sharp contrast; and a Robin or two, and a Brown Thrasher, and the Baltimore Oriole, gorgeous and lively; and his kinsman of the orchard, not quite so brilliant but none the less alive; and a Yellowhammer; and a Meadow Blackbird, who really ought to be out in the open;- these and others, all abundant in music; and, as we try to move in proper spirit with the 



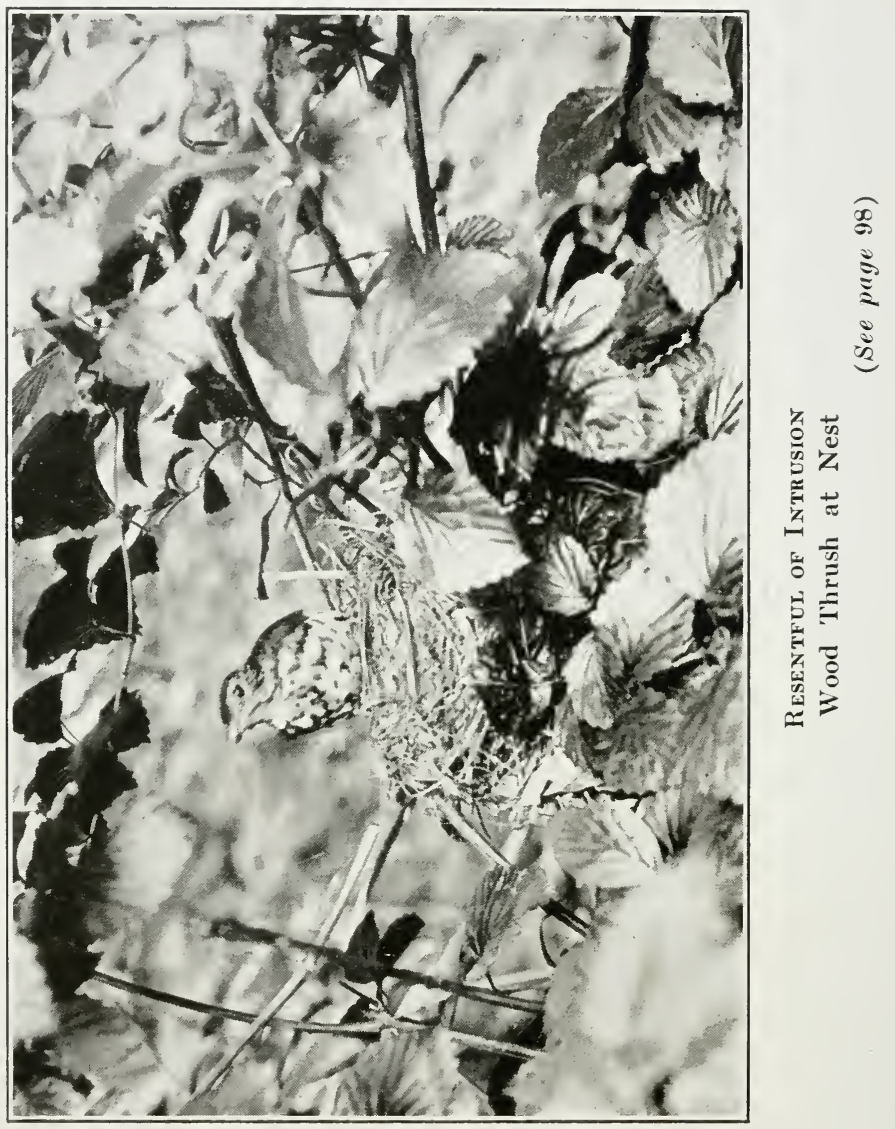




\section{Tanglewood Lane and Skippack Creek}

place and hour, most of it bidding us "welcome."

And now, tempted by a little opening in the bushes, we leave the road for a moment, climb the bank, shaking down a shower of blossoms in the effort, and, gaining the top, disclose a broad field running along the marge of a wood, and covered with coarse weeds and briar and patches of the mountain pink, with a fine panorama of blue sky and miles of rolling country out beyond.

Another irate Catbird forgets his manners and flies at us fiercely as we pass through; but we in turn forget him quickly upon hearing a faint, far voice from the upper air, and looking above discover two Nighthawks sailing along in quick, broken flight, and ever and anon swooping down with a rush and roar to capture a new tidbit for the evening meal.

But what is this that rises noiselessly right at our feet and hurries away? Of a truth the Field Sparrow, none other; andmirabile dictu!-here is his nest, without 


\section{A Book on Birds}

hunting for it-snug and cozy and beautiful-sheltered by a tuft of slender grasses half drawn together at the top like an Indian wigwam; and within its soft and silvery retreat four of the daintiest and rarest of eggs, of finer tint than many pearls, and not so very much larger than some, with delicate markings of five or six shades of brown to add to their beauty.

We would fain linger a while in delight at the "find." But there is a mellow, mysterious call from the shadowy wood just a stone's throw away and we follow on eagerly.

And now great oaks again look down upon us, and the lure sounds nearer and brighter and more musical. What can it be? The long days of absence have made us forgetful. Ah, now we have it! There he is on that hemlock just ahead, the Scarlet Tanagersplendid flame of fire against the dusky brown and green-his voice as rich and warm as his matchless carmine vestments, and far less concerned because of us than we have ever known him before.

[ 106 ] 


\section{Tanglewood Lane and Skippack Creek}

Over and over again he carols his golden strain.

A pair of sleek, long-tailed Brown Thrashers run along the ground, side by side, some distance ahead and disappear; a "Wild canary" chirps merrily and flies rollicking away-up and down, up and down, like a tiny canoe on the waves; then two Blue Jays rustle by voiceless, the only silent ones just now in all this dim-lit chapel of the woods, as if they felt their harsh and strident tones would be out of place and spoil the evening harmony; and far below-for the trees break off abruptly and there is a sheer fall of nearly two hundred feet as you look down-the limpid, winding water flows in noisy, babbling monotone over many a rock and shallow.

There is deep magic in it all. But across the valley the sun has dropped behind the hills; the Chimney Swifts outside are gathering for their mad, twilight frolic until dark; Crow and Blackbird caw and clack more drowsily, and we must up and away. 


\section{A Book on Birds}

The Phœbes say "good-bye!" But the Larks call, "come again!" And as we count the latter especially close friends we whistle back to these, only, a promise that we will.

Yet, to be exact, we do not really accept the invitation on their account alone but for all the other charms of this almost forgotten country road, so near the noise and bustle of the world, and yet so removed and secluded. 


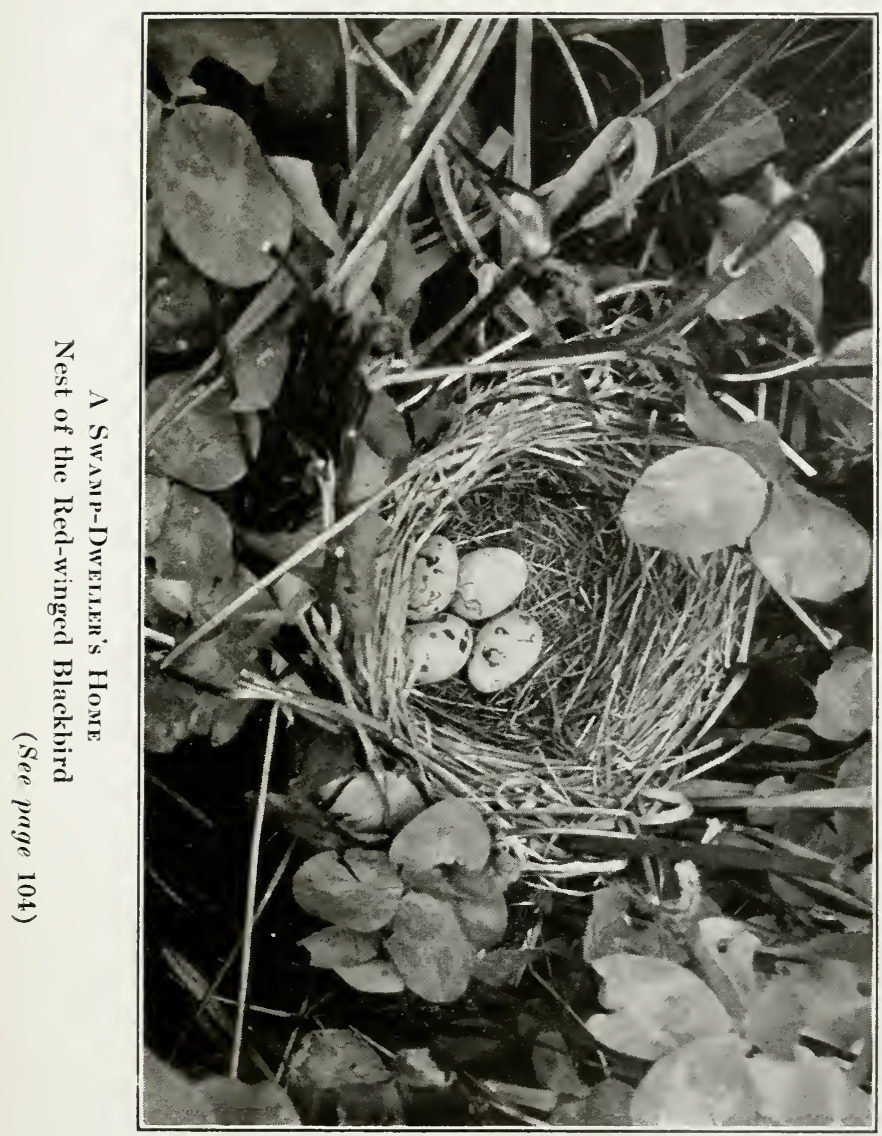





\section{Man-o'-the-Wood and Golden-Throat}

Man-o'-the-Wood and Golden-Throat

(Lines written upon meeting the Brown Thrasher)

"What are you singing for-Golden-throat?

The earth is empty here;

In all these forest aisles remote

There is not one listening ear.

That glorious strain, celestial bird,

Deserves a raptured throng;

To pour it forth alone, unheard, Seems but a waste of song."

"What are you loving for-Man-o'-the-wood?

With heaven in your face;

Amidst this utter solitude

All love is out of place.

Your Heart's-desire hath passed afar

To brighter realms above;

To keep on loving where you are

Seems but a waste of love."

"Just for the joy of it!-Golden-throat,

The joy a true love brings."

"And I, dear man, miss never a note

For the joy a true song sings." -

$\mathrm{O}$, blithesome bird-thrice happy man!

Such love, such song as yours

Made life divine when life began,

And will, while life endures. 


\section{Chapter VIII}

TWO VIREOS AND SOME FRIENDS

T ONE time watched at different periods of the day for several weeks a pair of Warbling Vireos that settled down for the summer in a large maple tree right on the turnpike road some three miles above my home.

They had built their beautiful, cupshaped nest in an overhanging branch some fifteen feet above the highway, and were not disturbed in the least by my ogling them through a field-glass to my heart's content; for the spot is a busy and noisy one in the summer time, with its rural trolley-cars thundering by and people getting off and on, and the birds seemed to have grown entirely unconscious of human affairs, and indifferent to what was transpiring down below their little aerial home.

While their music is still new to you, 


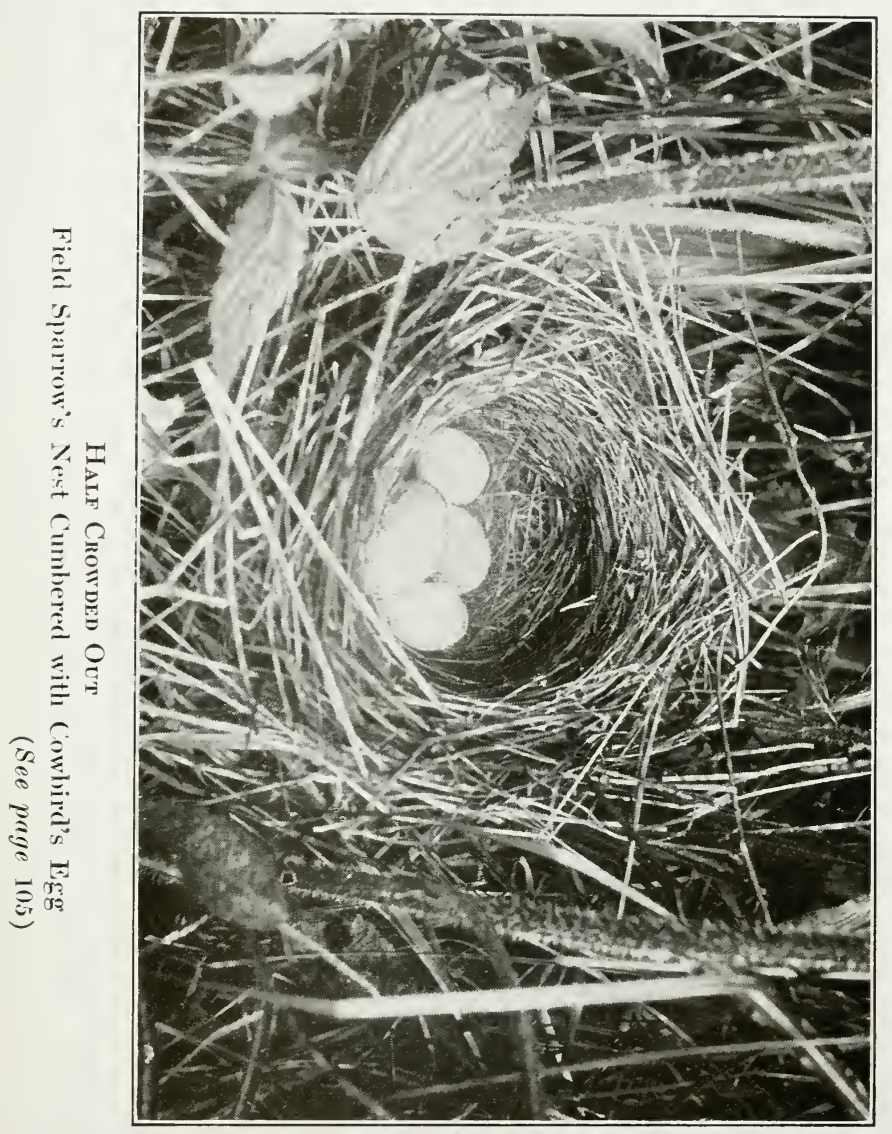





\section{Two Vireos and Some Friends}

you will probably mistake it for that of the

Wren. But after a bit you will notice that it is considerably fuller and richer than the smaller bird's strain, and altogether more melodious-even though, like the other, it is very much of a monotone.

In speaking of the Vireo's "music," however, we must not confound it with its "call"-which is simply one or two harsh, rasping notes that are quite distinctive and easily recognized. And just here it may be well to remind ourselves of the importance of knowing if possible in every case both these methods in which all birds find voice, so that hearing them we may not multiply new species out of the imagination, or make other mistakes by attributing the mere call and the real song to different birds.

The two Vireos of the maple tree showed the same delightful trait which some other species have of singing while sitting on their nest, each hopping off now and then to give place to the other. And they were of course most easily studied while so engaged. 


\section{A Book on Birds}

In general color they are a dull olive upon the back and wings, and a beautifully smooth dove tint over the rest of the body. Their habits are very dainty-their nest being a marvel of exquisite woven-work; while-among other refined little tricksthey have a most delightful way of slaking their thirst in the morning from the dewdrops on the surface of a leaf.

But let us also remember that there are two others in the same family it is just as pleasant to know-the White-eyed and the Red-eyed Vireos. They are all three so much alike that you will probably sometimes get them mixed, as I do; unless it is a bright day and you are near enough to detect the difference of color of eye in the several species, which really does exist notwithstanding the doubts of people upon this point. And do not fail to look for it whenever you come across any one of these birds, no matter how often it may fail to disclose itself; for then, sooner or later, you may duplicate my own experience (and the rare pleasure of it), in seeing a 


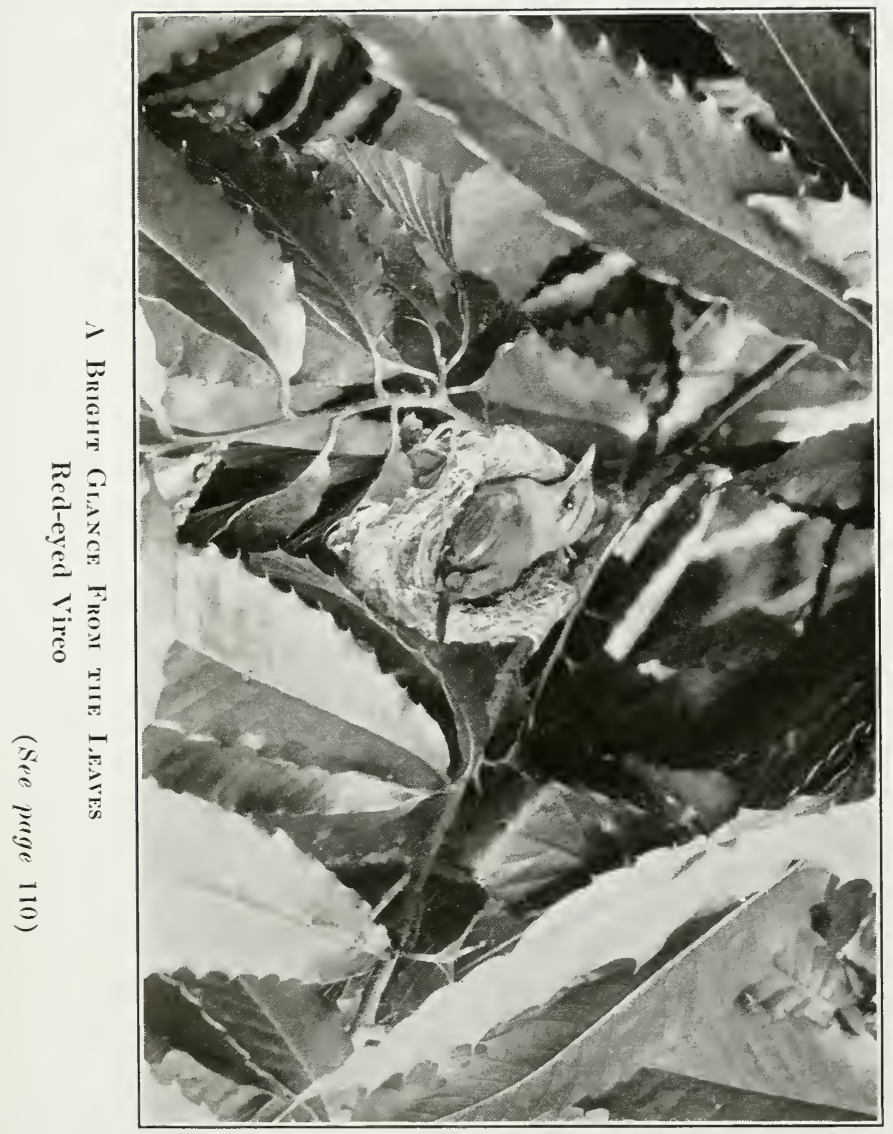





\section{Two Vireos and Some Friends}

stray sunbeam sift through the branches somewhere and actually strike the brilliant ruby of the lovely eyes of the last named of the three and set them all aglow like fire.

Nor, finally, must we forget an additional member of this clan-the Yellow-throated. He also resembles the rest except for the bright sulphur hue of chin and throat and his peculiar song of two quick notes whistled at intervals.

Not more than a mile from the Warbling Vireos' nest I once came upon the only Bobolinks I ever saw in this particular part of the country. They appeared in quite a flock on several old cherry trees in the midst of a meadow, and were giving vent to all the indescribable musical noise and chatter for which they are famous.

Moreover, it was early in May and they were arrayed in their new spring vestments -glistening black and white with a dull buff cap far down on the back of the head. For, be it remembered, the Bobolink, like some others, changes his garb with the seasons. And his name, too, by the way. 


\section{A Book on Birds}

Just before fall he looks as plain as a pipe-stem - in yellowish brown and grayand besides this has lost his music, and under the nom de guerre of Reedbird-has become the especial delight and victim of sportsmen along the Delaware river and bay.

Then, a little later, and still farther south, he assumes a new make-up even more faded, and, as the dreaded Ricebird, covers the country by tens of thousands and for a while gives the plantation owners all the trouble they can cope with.

But up our way-in the rare visits he makes us-he is nothing more than the jolly, rollicking Bobolink-always handsome to look at and a pleasure to hear.

And now - as a fanciful diversion in our bird-questing - let us shift the scene a little to get a sense of the weird and mysterious.

It still lacks a half hour of sunset; but up here, along this winding creek, in these dense, dewy thickets, rich with honeysuckle, the twilight has already fallen. So luxuriant indeed and tangled is the June undergrowth that you find difficulty in making 


\section{Two Vireos and Some Friends}

your way and must retrace your steps here and there to get through. And right in the depths of it, where you are completely surrounded and beset, and the leafy shadows are creeping in, you hear a low, clear, human whistle close behind you-just one, uncanny note, with a certain suggestion of meaning in it that makes you tinglelike the signal of some friend or foe.

Startled, you turn and look back, peering through the vines and foliage; but see nothing. Then you listen a minute, holding your breath. It sounds, again, but this time from in front, and you know now, from a peculiar inflection it has, that somewhere in that darkening mass of green a hidden eye is watching you. The whistle cannot be other than that of a bird, you think; and yet it certainly does sound like some man or boy.

Once more you hear it-directly overhead; and again, so close it seems at your very ear; and then, once more, farther off, to the left; and again, and againfrom nowhere and everywhere! 
Thoroughly baffled, you try your best, but in vain, to locate the elusive sound, with each repetition.

Then-just as you are giving up-you see a bright red figure-like a diminutive Mephistopheles-sitting absolutely motionless on a branch scarce ten feet away.

Of course you know him at once for the brilliant, but erratic Cardinal, or Virginia Red-bird; the one who looks so like the warm-blooded tropics, and yet insists on staying right up here in the North through our hardest winters, making himself at times, after a snowfall, glorious to behold, above the dazzling whiteness of the fields-a sort of hostage given by May to December for the sure return of spring; and whose second most distinguishing trait, I think, is that he can hide better and longer-making music all the timethan any other feathered denizen of field or forest.

Now that he sees you he sits as still as a statue until you make a move toward him; whereupon he flies off, to hide again 



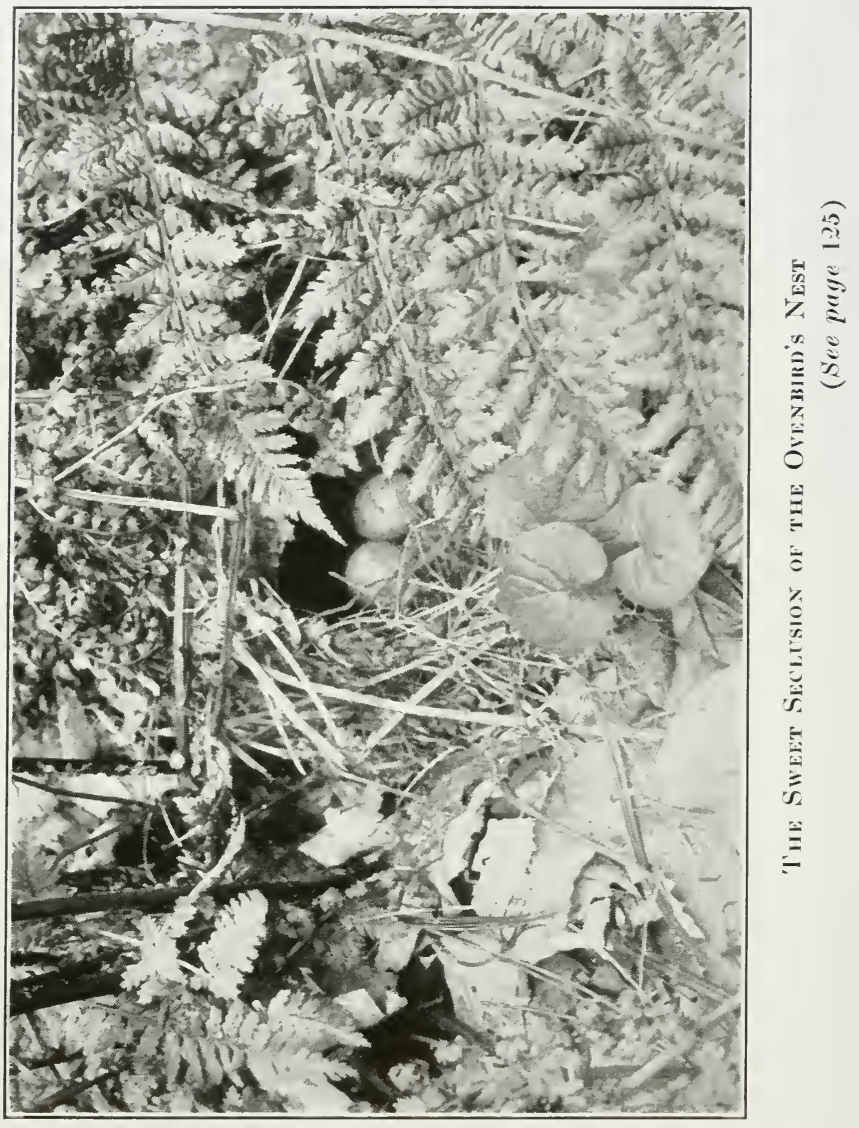




\section{Two Vireos and Some Friends}

at a little distance, and pour forth enough gymnastic variation in his wonderful whistle to drive a boy-adept at the art to despair with envy; all of which, however, is simply an indication that you are near his nest and he is alarmed about it. Moreover, he stirs up some other sounds with his melodious noise that are not echoes-and in a moment or two you have had a vision of the Maryland Yellow-throat, the Yellowbreasted Chat and the Indigo Bunting; these - with the Cardinal added-forming as rich and as rare a woodland symphony in color as any one may wish to look upon; and so brightening up the shadowy thicket that you emerge at length with feelings very different from those with which you were held fast in it, or threaded cautiously its wilding maze, but a little while before. 


\section{A Book on Birds}

\section{O Love Divine}

O Love Divine!-He came, and gently singing At earliest dawn in secret to a bird, Thrilled it with joy till it awoke, and winging Its way aloft, proclaimed Him with no word,

Yet surely, sweetly, by the holy sign Of His own melody. O Love Divine!

Then, in a little while, bent low and kneeling Deep in a leafy wood with dew bedight, He lured a wilding flower forth, unsealing Its tomb with living touch, and toward the light Turning its face, that these dull eyes of mine Might trace His presence too. O Love Divine!

Nor this alone: but, where angelic fingers

Wove pearl and rose amidst the orchard trees, He came again - to breathe the breath that lingers, When Spring is at the flood, on every breeze; That, deaf and sightless, I might not repine, But still discover Him. O Love Divine!

And then-e'en at my hearth-when day was ended, And in the dusk I soothed my suffering child, $\mathrm{He}$, crowning all His tenderness, descended

Once more, unseen, and where I sat beguiled The little one to sleep. "Ah-else than ThineThere is no heaven!" I cried: Thou Love Divine! 



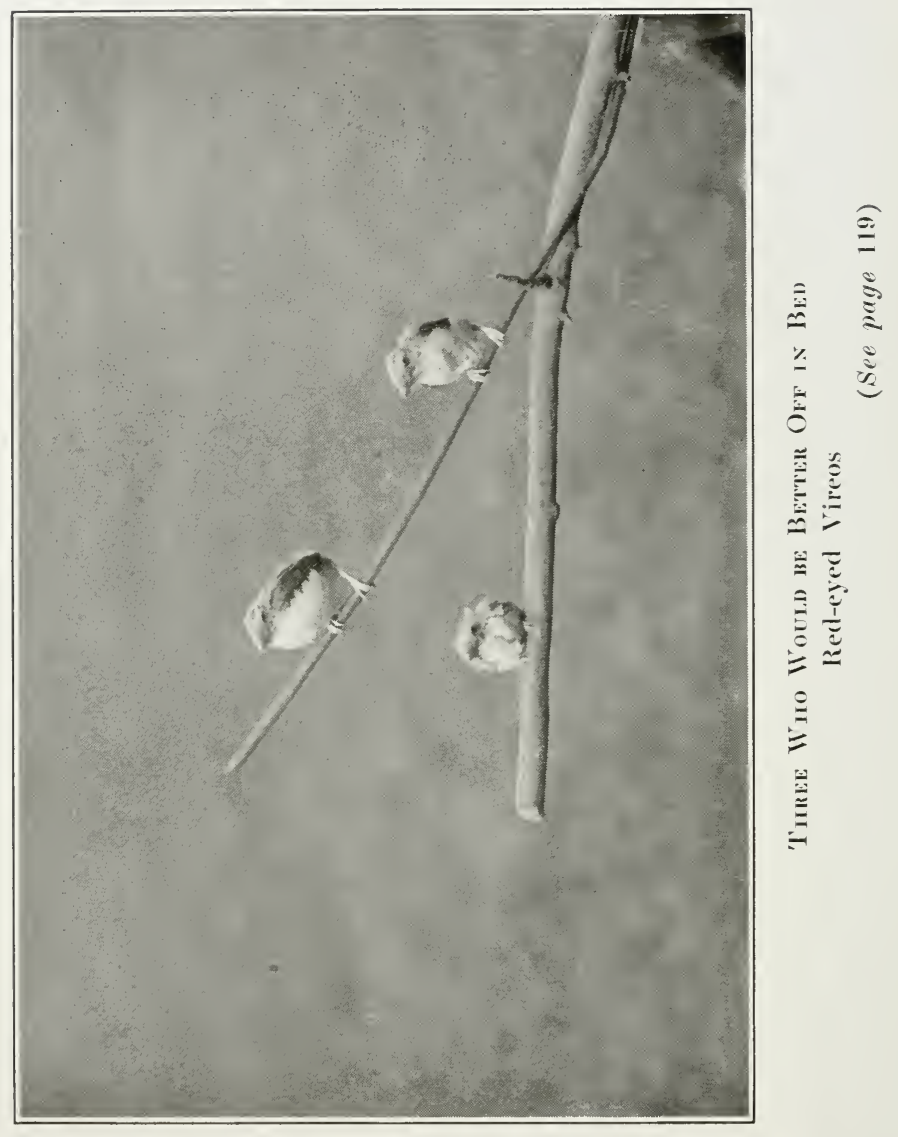




\section{Chapter IX}

AT THE END OF JUNE

T $T^{E}$ have come at length in our impromptu excursions out among the birds to that deep and busy season when, though just as numerous as ever, they are very hard to find.

One bright, warm day when the first of July was less than a week ahead, I sat in a clean, cool, mossy wood which lies along a cross-road on the way from my home to the village four miles distant that now, after many years, bears Audubon's name, and listened on a big log, about six in the evening, until I heard the calls or the singing of at least ten species, not one of which (wait and search and lure them as I would) was I able to get a glimpse of.

Included in this number were the Blue Jay, the Yellow-breasted Chat, the Redeyed Vireo, the Yellow-throat, the Crested 


\section{A Book on Birds}

Flycatcher, the Wood Pewee, the Spotted Sandpiper and the Yellow-billed Cuckoo, all of them making considerable noise and music, but not one of them ever in sight. And the same condition, in a general way, prevails everywhere at this time of the year.

Of course, there are reasons for this; and two of them-not to mention othersare quite easily understood.

First, the density of the foliage by the end of June conceals a bird over and over again, even though he is not thinking of it, or gives him unlimited opportunities to hide when he is. And the fact of the matter is that, as a rule these days when you are around, he is actually trying to hide.

And with a wise purpose, too. Field and forest are full of mystery in the month of roses. There are gentle secrets almost everywhere. And those the birds know they are sparing no effort to keep to themselves.

It is on this account they are stealthy and endeavor to baffle and mislead you with elusive sounds. 


\section{At the End of June}

You are in dangerous proximity to a nest, perhaps, and they must draw you away!

Or, it may be, only a yard or two from your peering eyes-that search but see not-is a fledgling spending his first day from home on a branch where the leaves are thickest and hardest to explore; and the parent birds are hoping with all their woodland hearts you may not discover him.

Moreover, they will resort at times to art and strategy to divert you. I have been convinced on one or two occasions that some birds really become ventriloquists of a sort, when driven to it. Their voice will seem to fall from in front and from behind at almost the same moment, until you give up in despair trying to locate it.

And others have other tricks by which to save their nests and their offspring should occasion demand. Often have I seen the Turtle Dove, when surprised upon his nest, drop to the ground and go struggling away, in short, quick hops and broken flights, as if wounded, so that you may 


\section{A Book on Birds}

follow after and try to catch him and thus be led afar and wide from his rough home of sticks, with its two white eggs. And he is not the only bird who goes through this performance, or many another, with the same object in view.

So, going back to the point we started with, do not be disappointed in your questing these golden hours, if you hear much but see little.

And yet, after all, there will be exceptions to this rule and many a bright feast for the eye even now. Indeed the brightest of all awaits you if you go far enough; for the Scarlet Tanager is about and I have always thought it is he who likes to sit still and be looked at and admired more than any bird we have.

Nor can he fairly be blamed if he does, his beauty being almost beyond description. All other color in the forest pales before his splendid, royal carmine, made almost luminous against the living green by the sharp contrast of jet black eyes and wings. Sometimes when the sunlight 


\section{At the End of June}

strikes him he seems a very burning brand, dropped from heaven through the treetops to make us dream of the glory of the God that made him, and worship just a moment all alone, in His fragrant, dim-lit temple. And, furthermore, your delight in the beauty of this bird will be increased should his mate, in her garb of faint green and yellow, happen to join him as you gaze, and heighten the picture he makes.

You may find the Tanager any evening after June fifteenth, if you will, from six until seven, or even later, at the very next patch of woods beyond that which I have already mentioned. The oak and hickory trees here almost surround a little structure known as the Indian Creek school housethis, by the by, being about the most rural and picturesque building of its kind one could imagine, an ideal haunt for some new Rip Van Winkle. Its outlook in every direction is a charming one of leaves and branches, several great, tall forest sentinels standing apart from the rest right beside it, and affording fine and ample shelter 


\section{A Book on Birds}

for its pupils (it had thirteen all told, when

I was there) and teacher.

However, to return to the Tanager, just a stone's throw away! You will not need to go more than thirty or forty feet into the woods before you hear him repeating overhead his two sharp, unmusical notes"chirp, churr! chirp, churr! chirp, churr!" again and again. You have frightened him from his nest, which is up on a horizontal branch somewhere; but, exceptional fellow that he is, he sits quite still and gives you plenty of chance to study him till you are tired.

Or, until your attention is diverted by the call of the Yellow-billed Cuckooor Rainbird; for he is here, too; but, like the others, hard to find. $\mathrm{He}$ is a large, fine bird, as smooth and quiet in voice and every movement as in color, except, perhaps, for the loud, melancholy cry, often heard of a sultry afternoon, with which he is said to prognosticate a thunder shower.

While you are trying in vain to locate him, the big, sharp, saucy note of the 


\section{At the End of June}

Ovenbird breaks forth close overhead. And here, indeed, is a problem; for not one time out of ten will you be able to get a glimpse of this fellow, despite all the reckless noise he makes.

"Teacher, teacher, teacher, teacher, teacher!" he gushes out once more, the notes increasing in rapidity, volume and impudence to the end, and seeming so close you feel you could stretch out your hand and touch him, if you only knew which way. But find him if you can-with his little golden crown!

And as to his nest, it is in a bank somewhere, with a roof over it, and is an even harder proposition, so don't try; or, rather, do not be disappointed if you try and fail. For only the patient, expert naturalists, and not all of them, achieve the high distinction of actually discovering the nest of this bird.

On my own way back from this patch of woods I met a pair of Tyrant Flycatchers (Kingbirds) still engaged in collecting out of the "circumambient air" their evening 


\section{A Book on Birds}

meal of moths and other insects from the vantage of a telegraph wire. These are the little fighters that may be seen circling around a clumsy Crow on the wing and harrying it to complete exhaustion. And yet, in a fair contest, they are arrant cowards notwithstanding.

You can identify them by their sharp, quick cry in flight; the nervous, jerky motion of their wings; the conspicuous border of white, straight across the end of the tail feathers; and the low tuft of feathers, with its scarlet spot, adorning the head.

Somewhere in the neighborhood also is their near relative - the Crested Flycatcher, top-knotted far more than they, and keeping an eye on his nest in a tree-hole-with its odd, chocolate-streaked eggs.

And then, where the stream crosses the by-road, a Spotted Sandpiper sounds his high-keyed cry and scurries along above the water. The way in which his short, flat tail bobs up and down unceasingly, every time he alights upon a stone, on the 


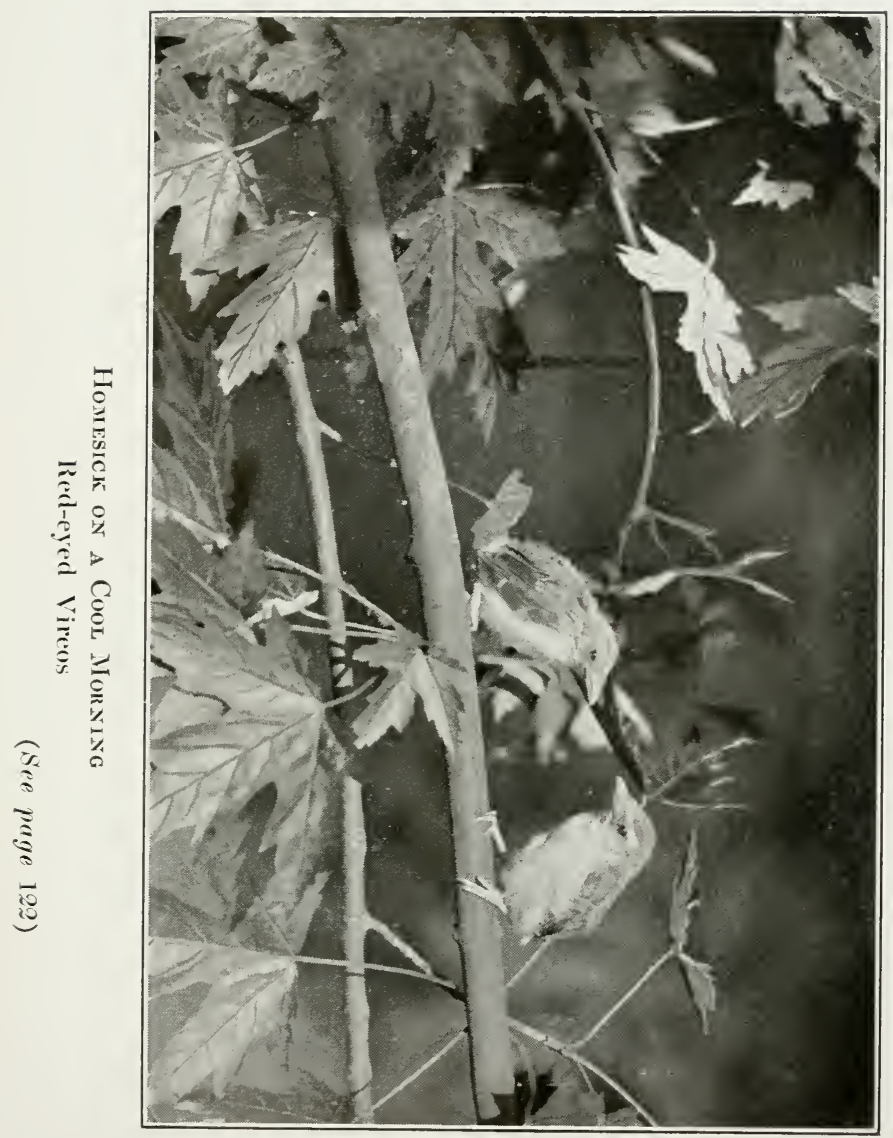





\section{At the End of June}

bank or sticking above the tide, is one of the funniest things in nature. He seems to have lost his balance somewhere, away back at the beginning, and never to have been quite able to recover it since then, try as he will. Yet he is a bright, clean, handsome bird and gay of spirit, none the less.

Just as his tinny note dies out in the distance, my approach stirs up a little Screech Owl, who, first giving me a wooden stare, as he sits straight, trim and dignified on the dead branch of a willow, moves off with slow-flapping wings, in soft, noiseless flight through the deepening shadows.

And then, noting how close indeed the dark has settled down, silent and furtive as a Cedar Bird (of whom a word in another chapter), I myself take the hint and move off too-toward the highway and home. 


\section{A Book on Birds}

\section{The Oven-Bird}

"Teacher, teacher, teacher, teacher, teacher!"

Was there ever such a saucy creature?-

Boasting loud and clear, in your very ear,

That you cannot find him, far or near!

How he sets the forest aisles a-ringing

With his merry notes, more noise than singing!

And how impudent is his plain intent

To divert the quest on which you're bent!

Surely, now, you think, he's over yonder;

But, next moment, as you peer and ponder, Quick and bright and gay as a boy at play, He invites you, "Look this other way!"

Yet, don't blame him; birds have many a reason In the deep, mysterious summer season, Thus to call and hide, and to lure aside Those who seek and will not be denied.

In these ferny, redolent recesses,

Just where one least dreams of it, or guesses, Nestling in the ground, he, the Golden-crowned, Has a home 'twould grieve him were it found.

Yes, 'twould put him to complete confusion Should you stumble on its sweet seclusion. So be kind to him-have a mind to him, As you tread these pathways cool and dim. 


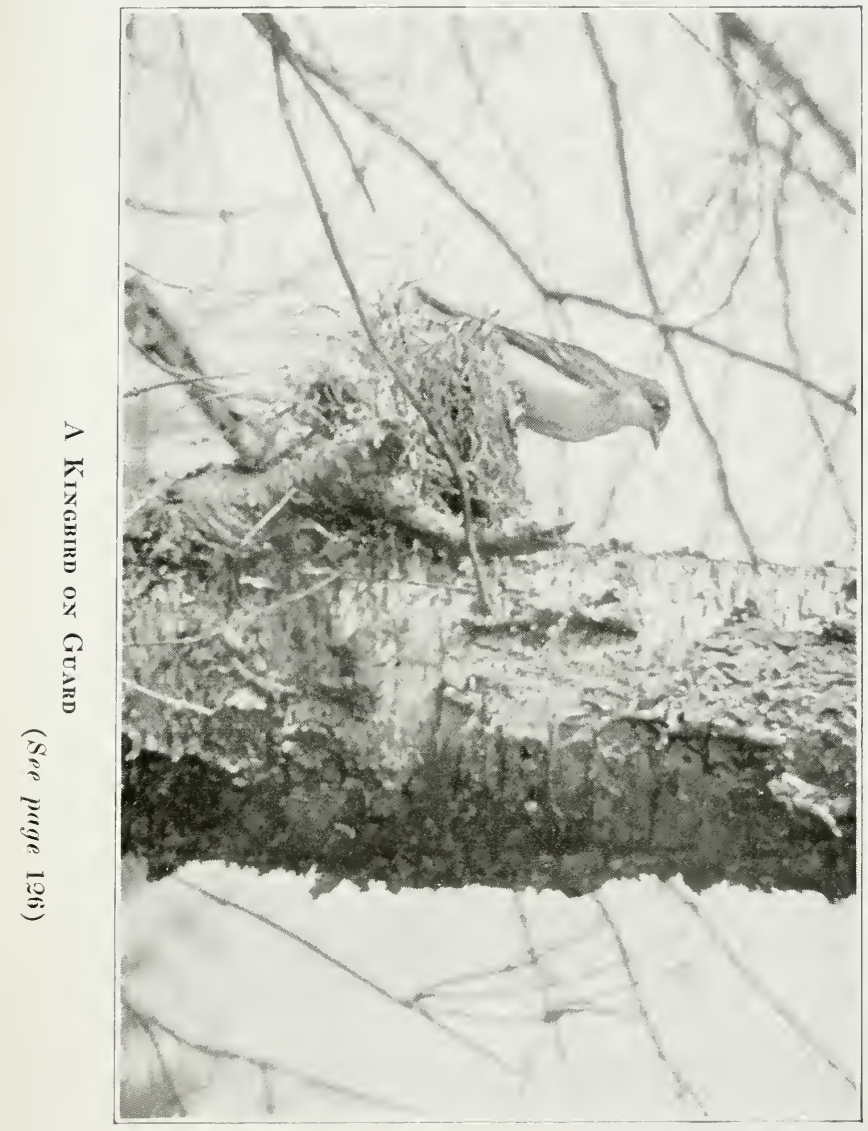





\section{Chapter $\mathrm{X}$}

BIRD SONGS AFTER DARK

UT on this broad Pennsylvania wheatfield, at two o'clock in the morning, with the yellow sheaves beneath and around us, and the full-orbed moon above-surely this is no place, no time, for birds!

Were it merry England, a Nightingale might come perchance and keep us company, with his matchless voice. But here it seems folly to expect any wingéd creature to waken and cheer the solitude by so much as a sound.

Yet, listen! That is more than mere sound which thrills upon the air.

The flooding silver light from an almost starless sky is wonderfully clear; and the winding river, showing through the distant trees beyond the sloping hillside, glistens and flashes at times almost as if it were day. 


\section{A Book on Birds}

Listen again! That, indeed, is more than mere sound. It is music; music sweeter for the silence and the far spot whence it is borne; music that we know!

Of a truth it is none else than our brave little friend the Song Sparrow, warbling as he sleeps, it may be; but in the same happy tones which make his day-dreams so melodious.

We quicken with pleasure as we hear him. Some doubts are already dispelled.

We had known of course that many American birds, including the Owls, give voice at night; but we hesitated to believe that any of our genuine songsters actually sing. And here, sure enough, is one to begin with; and we are put to shame for our incredulity.

And yet it is not he for whom we really came.

"Will his melody stir the slumbers and the voice of another?" It is this other who brought us out; and he is still uppermost in our thoughts. Will the Thrasher, (the Brown Mockingbird) whom we admire 


\section{Bird Songs after Dark}

as much as any Briton his noble Nightingale-will he add his tuneful testimony, as we have been told we may expect him to?

The brooding stillness settles down again. A half-hour goes by. The snugly packed sheaves make a warm and comfortable bed, and we are getting drowsy. When, lo, behold-not the Thrasher indeed-but one more, almost as worthy, our "stringer of pearls"-the Spizella pusilla-breaks forth, putting Morpheus to flight!

"True-true-true! ever true to thee, dear Heart!" fall his notes from a branch just where the trees begin; not one bright gem missing, but all of them lovelier for the moonbeams and the eager ear of night.

And this time doubt diminishes to almost nothing, while expectation rises high. Will the Thrasher verily pour for us his rich libation next?

The minutes wear on. We half nap a while, and waken to hear the "Peep, peep, peep!" of the Sandpiper, and the fuller cry of the Killdeer, both exactly as they are during the day. 


\section{A Book on Birds}

Then comes another, longer period of somnolence, from which a Robin, off in the gloom somewhere, delivers us with his most extended strain. And later on the Flicker and the Grasshopper Sparrow sing.

But that one golden throat, which so far surpasses all these, and which, heard in the darkness, we had fancied might vie with the Nightingale's, is still missing; until doubt asserts itself again, and the silver flood from the sky begins to seem poor and pale and sorrowful for lack of it.

The "Caw, caw, caw!" of a Crow, flying too high overhead to be visible, sounds like mockery of our expectations. Then a noticeable chill in the atmosphere creates a creepy feeling; which increases as the Yellow-breasted Chat flings out his weird, uncanny notes, as if in actual derision.

And so the night passes; until a last long interval of semi-consciousness is broken by the clarion call of Sir Chanticleer from the barnyard beyond the hill to which our wheat-field is appurtenant; and, rising suddenly, somewhat bewildered, we discover 



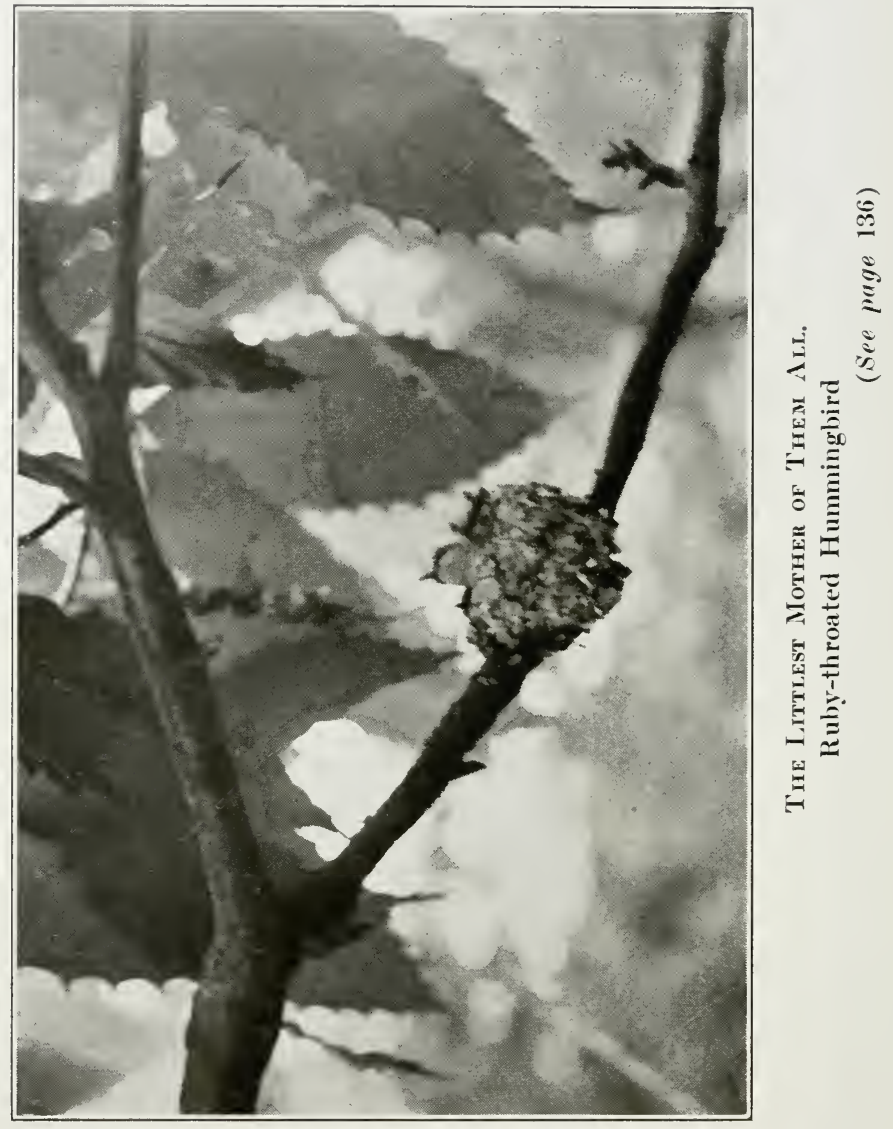




\section{Bird Songs after Dark}

a faint crimson glory on the eastern horizon and know our vigil out in the open is practically over, with all present prospects of a song in the dark from the Thrasher at an end.

However, we do not feel that the exploit has been in vain.

Have there not been other voices to satisfy our ears? And if these, then why indeed may we not hear also on some future occasion the one which has been conspicuous by its silence this time? 


\section{A Book on Birds}

\section{The Meadow Lark}

Clear, clear-far or near, Bird o' the morning, call!-I hear.

Out of the swift advancing light Rising brighter and more bright At the end of each quick flight,Meadow Lark, call!-I hear.

Call, call!-for of all

Lures of melody, this the thrall

Dawn, awakening in thy breast,

Flings forth tenderly to the west,

This, oh, this is loveliest-

Loveliest lure of all.

Free, free-bush nor tree

Shut the goldening skies from thee!

Deep in the clover-field abloom,

Fragrant, billowy, great with room,

Wide apart from the forest gloom,

Thither thy nest shall be!

There, where-all the air

Bloweth halcyon, hale and rare!

Up and on with the buoyant day-

On into noon and evening gray,

Seeking the mountains far away-

Hale and halcyon air! 



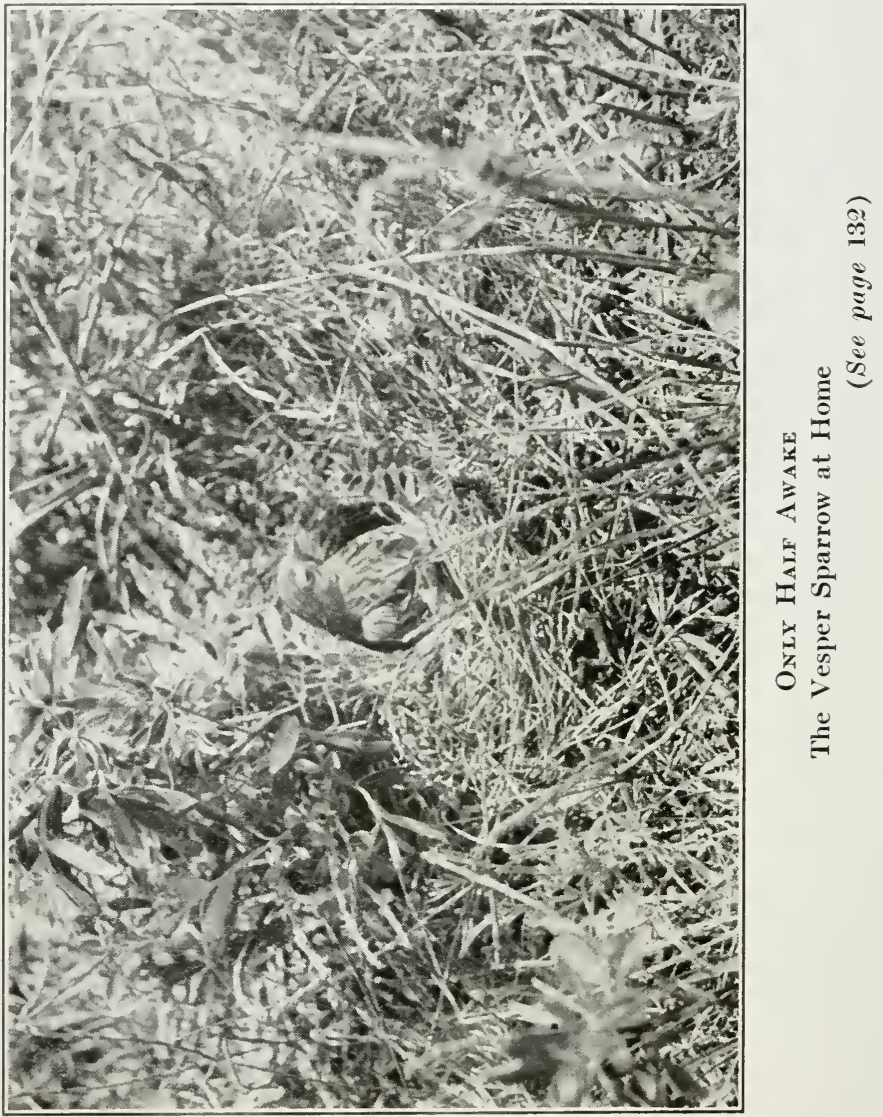




\section{The Meadow Lark}

Joy, joy!-flute, hautboy,

Pipe, or piccolo seems a toy,

Poor and empty, with thy rich voice,

Caroling, silver-sweet, rejoice,

Silver-sweet, rejoice, rejoice-

Unto th' heights of joy!

Clear, clear-far or near,

Bird o' the morning, call!-I hear;

Finding with thee (out, out between

Th' boundless blue and rippling green)

My heaven not remote, but e'en

Gladsomely, gently near. 


\section{Chapter XI}

\section{MIDSUMMER MEMORANDA}

7 HE wave of silence which submerges bird music almost entirely in our climate, except in rarely cool weather, by the end of the wheat harvest, is wont to throw one back more or less upon those earlier days when there was a call from every meadow and a song from every tree.

Moreover, we are fortunate if there are for us in truth some such unforgotten hours to which we may revert at this season; and doubly so if we retain any clear mental memoranda gathered in them which may still be marshaled in good order and jotted down; as most of the very birds themselves seem now to disappear along with their music; and we should consequently, if debarred from retrospection, have often but a dull and lonely time of it indeed. 


\section{Midsummer Memoranda}

As for myself, I have always been able to retain quite enough to occupy my mind when necessary out of these things of the past, which accumulated so rapidly while they were transpiring that it was impossible to keep full pace with them then. Furthermore, this midsummer in which I write seems to give fuller proof of the fact than any of former years; a great throng of recollections of this sort pressing in upon me almost daily as never before. And for some reason at the present moment those of the charming little Acadian Flycatcher are in the lead.

However, the Acadian comes first probably because I have found him tamest and most companionable of his clan. His kinsfolk, the Crested and the Tyrant Flycatchers, always treat your approach as an unwelcome intrusion, the voice of the former being marked by a tone of chill surprise when he sees you, while the highkeyed, nervous notes of the latter are full of actual resentment and alarm. But he himself, though much less in size than they, 


\section{A Book on Birds}

looks upon you quietly, and seems not at all disturbed over your presence, but pleased.

Once, toward evening in a deep thicket redolent with the ivory-white clusters of the wild-cherry, he was so interested in the frequent short swoops he made through the branches close to the ground, while capturing gnats and flies for supper, that he appeared almost inclined to invite my co-operation with him in his efforts, nearly touching my head several times, or even alighting upon it when his victims flew close to me; until I think he might have taken them from my fingers had I tried to catch them for him.

And he is not only tame with those whose woodland manners are correct, but also very beautiful of form and color. The dark, rich olive of his back and tail makes a charming foil for the wavy stripes of pure white upon his wings, and the delicate yellow of his breast. His head, which has only a suggestion of the crest which is so conspicuous in others of his family, is 


\section{Midsummer Memoranda}

shapely, and he is as graceful and smooth in every movement as a Wood Thrush, and just as self-contained, though much livelier of course.

Next in this bright, insistent throng of recollections the merry, buff-capped Bobolink presents himself.

He was always really a stranger to me outside the books until I came across him one peerless morning about the middle of May up in the Raritan river country of New Jersey. Since then, however, he has been an unfading friend. Even as I write I can recall him and his glorious environment that day with vivid distinctness.

Far out in the open, under the blue of heaven, where snowy cloudships sail in glistening splendor, the broad meadowssupremely luxuriant after the freshening rain of the night-stretch straight away for a mile or more to where the silver ribbon of the winding stream is hid by a fringe of darkling trees. And in every direction they unfold a soul-stirring vista of living green made luminous with gold; 


\section{A Book on Birds}

for north and south, and to the eastward where the ocean lies afar, they are arrayed just now in one rich covering of dandelions and clover.

Behind me, toward the west, billows of perfume sweep by and pass beyond, from an apple-orchard of a hundred trees, each one of which is a mass of scented bloom.

And ever in the foreground, flitting from meadow to blossoms-where Wood Warblers are feeding - and back again, the Bobolink keeps his gladdest holiday of all the year, his last before nest-building, while still the cares of life have not begun, and he has naught to do but feed and fly and ease himself of the music in his soul.

And how wild with joy he is! How utterly carried away with the softly-swelling tide of spring, spring, spring! $\mathrm{He}$ cannot shut off for a single moment the fountain of sparkling sound that leaps and spurts and gurgles from his breast; but, filled with exuberant ecstasy, lets it flow right on, whether he is standing, half- 


\section{Midsummer Memoranda}

hid, on the ground, or swaying daintily on a tall weed, or is perched an instant on a fence-rail, or even poised above you in mid-air, with restless, palpitating wings.

There are not so many birds that sing while in flight. But the Bobolink does it to perfection, pouring forth his notes from an altitude of fifteen or twenty feet in such showering brilliance that you can almost feel and see the flash of them as they descend.

As he sings and flies, and flies and sings, and circles about, quite agog with melodious excitement, you get the impression that he is afflicted with a foolish fear that you are unaware of his presence, or even of the matchless glory of the day. And after a while you half feel like shouting a little and breaking forth into rollicking song yourself; or actually jumping around a bit-with a toss of your hat in the air, and several handsprings and a vault over the fence thrown in-just to relieve his apprehensions and show him you are alive to the situation. 


\section{A Book on Birds}

However, you don't do anything of the sort; at least not on this initial occasion; but simply look and listen in astonishment and delight, thinking how much indeed you missed by not getting thoroughly acquainted with him until so late a day in your ornithological career.

And now, from amidst the same midsummer flight of wingéd memories which still encircles us, suppose we permit the Barn Swallow to engage our attention.

Should you ever feel upon a particularly vernal morning that you are advancing in years, and, stirred by the sunlit air, wonder to yourself whether any of the pure spontaneity and freedom of childhood still remain in your anatomy, let me suggest that you sally forth and search till you find a field near some farmhouse nestling amidst the hills-a field with nothing between it and the azure firmament but one or two white and dazzling "skymountains," towering in great masses toward the zenith-and there try a game of "dodge-the-ball" with this jolly bird. 


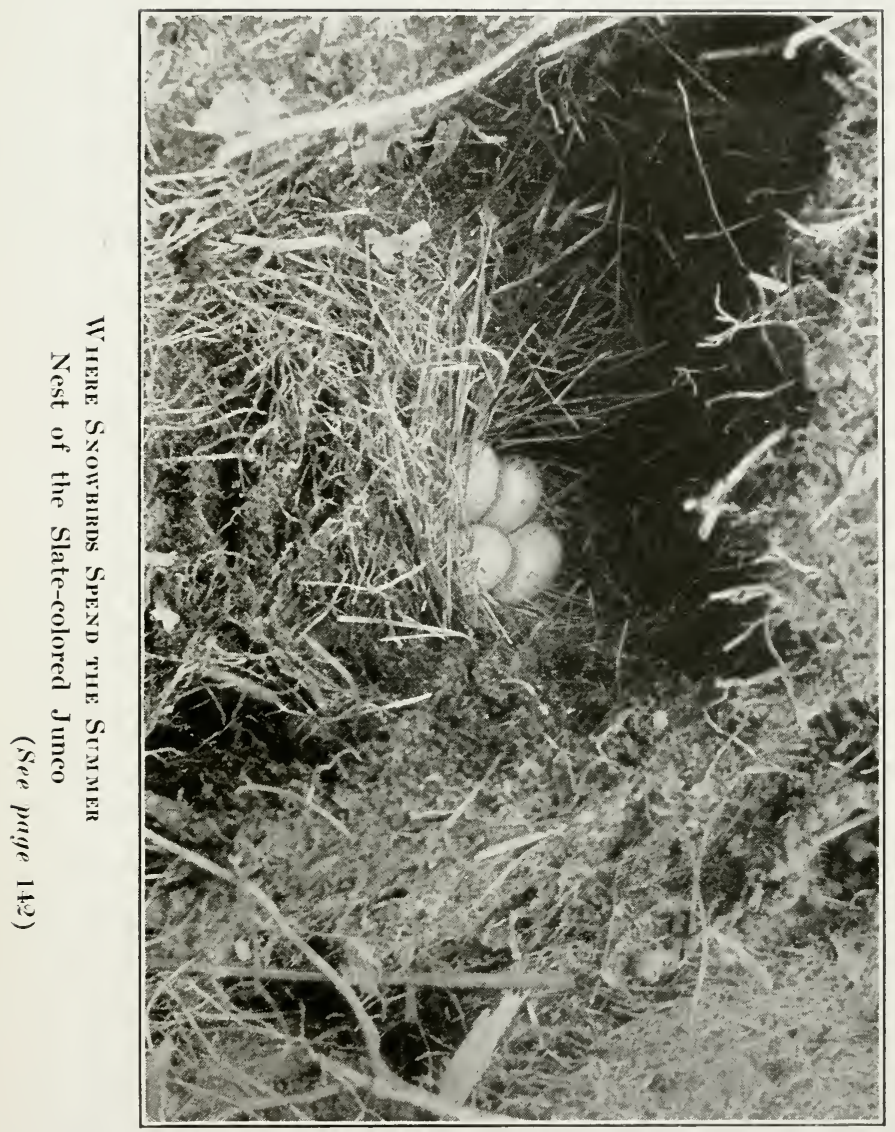





\section{Midsummer Memoranda}

If that test fails, your case is serious, indeed, and you can hardly hope that the deepest draughts you may drink from all the fountains of youth this side eternity will ever do you much good.

To make the test perfect the field should spread out wide and beautiful upon a gentle slope, beyond a wooded ravine, faintly musical with laughing water; the cool west wind should be blowing lightly across it; there should be a wealth of violets thickly scattered in amongst the dewy grass under foot, and away over in the open a single tall oak, still leafless, should rise sharply clear in every black outline against the far horizon, to give perspective to the scene and lift it heavenward.

But, with these conditions around you, the rest is easy.

Here he comes now! first from the hayloft-exactly when you have climbed the round ascent sufficiently to get your vision on a line with the level lay of the ground at the top. Here he comes now!-skim- 


\section{A Book on Birds}

ming over the clover, straight for your face, his blue back glistening, his breast warm and ruddy, his forked tail (and he is the only bird in our climate that has a genuinely forked tail) as stiff and straight with the speed of his flight as the barbs of an arrow. Here he comes now! Quick, dodge! Good, you're safe!

Yet it was not your dodge that kept him from hitting you, but his, when he was scarcely ten feet away.

Look out! He's coming again; back of you this time. Quick, dodge! There! -he just missed your ear. But it was his miss once more.

Yes, that's right! Make a swipe at him with your hat as he passes; but don't hit him-because you can't; and it's a waste of energy to really try; for he will escape you, even if it be only by the fraction of an inch. But swipe away, nevertheless. The more of it you do, the quicker and oftener he will return, being as fully alert and alive to the game as you are, and enjoying it quite as thoroughly. So 


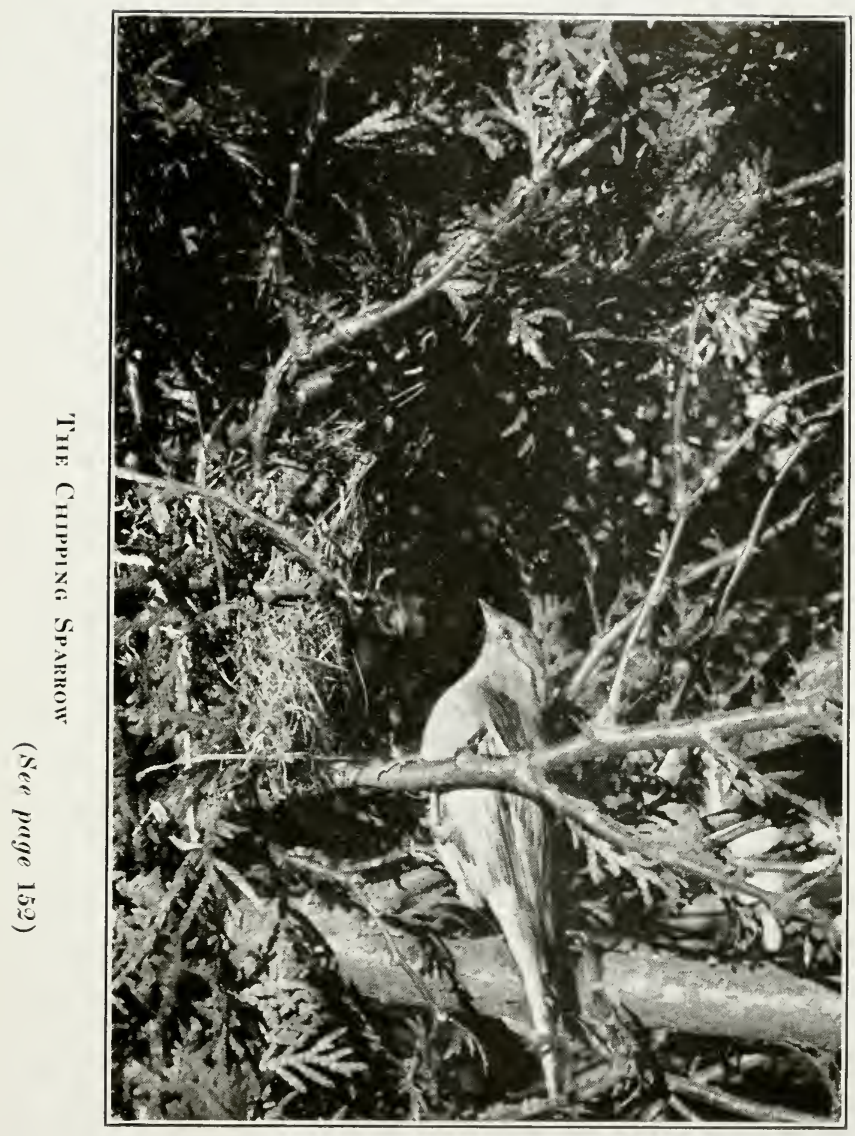





\section{Midsummer Memoranda}

dodge and strike to your heart's content, until you have reached the fence on the other side of the field and are ready to take a rest on the top rail, and laugh at Mr. Swallow, as he gives you up reluctantly and hies him off to his brown-speckled eggs and nest of mud and feathers against the rafters over the mow.

Who has not played the game that ever loved the open air?-even to three-scoreand-ten, it may be-and who that ever played it has not felt when it was over that it did him good and made him at heart for a while as a child again?

Of all the birds I knew in boyhood days the Cedar Waxwing seemed the most mysterious; and upon those rare occasions when I came across his nest in the dark recesses of his native tree, the find never failed to give me just a little of the creepy feeling a witch story produces when properly told.

Undoubtedly the fact that he seems to possess no voice at all, (or, if he has any, neglects entirely to make it known) had 


\section{A Book on Birds}

something to do with this. Throughout my whole acquaintance with him I have at no time heard him utter any semblance of a song. Indeed, I might just as well have said "any semblance of a sound"; for in his smooth and stealthy gliding about from twig to twig, and tree to tree (his every motion furtive, yet calm and dignified, too) he is absolutely noiseless, as far as I have been able to discover.

And then his color-scheme also adds to the weird impression he creates-although, be it said in justice to him, he is nevertheless, after his own exceptional kind, a most striking and shapely fellow. It consists of several dull, unnamable shades of brown, the darkest on his fine topknot or crest (which, to be exact, is neither of these, but, rather, a broad though abbreviated plume) and the lightest upon his breast and rump.

His other colors, however, are not dull or quiet by any means, but most conspicuous - from the bright yellow border across the end of his tail to the brilliant carmine 


\section{Midsummer Memoranda}

of the horny substance (resembling red sealing wax) which tips the feathers that terminate at the middle of each wing, it being from this peculiar mark that he takes his name. Then he boasts in addition some striking dashes of black and white around the eye, along the edges of the wing, and upon the tail; these completing an array which invests him with a truly strange atmosphere of distinction in keeping with his habits.

Notwithstanding his solitary disposition, the Cedar Bird is not at all impossible to find in our climate by the end of May, and he is well worth adding to your list of intimate acquaintances, his very oddity creating a special fascination and interest which you will hardly fail to feel at once.

That loud, insolent whistling you hear from somewhere up in the buttonwood tree is the voice of the Yellow-breasted Chat; and at the moment, for special reasons, his notes are at their worst.

Most Wood Warblers are entirely sweet and subdued in all their music and bird- 


\section{A Book on Birds}

talk. But the Maryland Yellow-throat, the Ovenbird, and our present specimen, the Chat, are pronounced exceptions to this rule, the last-named in particular being often noisy to the last degree, and giving vent to sounds when excited (as he is just now) of which he ought to be ashamed. Some of them are an unpleasant clash between the notes of the Robin and those of a Parrot; while others are nothing else than ugly, rasping, guttural expletives -as you will observe-and all because we have come too close to his nest, with its white and brown eggs, in this wild-rose bush on the edge of the swampy thicket.

And yet, despite his unfortunate, illbred voice, the Chat is a very charming bird, though, of course, the old adage about "fine feathers" must not be entirely forgotten. But, indeed, you may be the more apt to forget it in his case, because his plumage is not mere vulgar showiness, like the Peacock's, but is delicately beautiful, in its two dominant hues of olive green upon the back, and soft, rich yellow underneath. 


\section{Midsummer Memoranda}

Nor has he any other bad traits I know of, save those his voice gives him. He is devoted to his home, after he has once completed it for himself; and-braver than some others-will not desert it offhand merely because you and your friends, it may be, intrude a little on its privacy.

This I can vouch for from personal experience; for the nest in the rose bush, to which I have referred, was not a myth, but a nest I knew; and though my inner circle of amateur ornithologists made it a veritable Mecca for a week or two, creating a beaten path through the meadowgrass to it and all around it by their frequent trips, its owner, the Chat, stood by his little castle just the same and raised his brood of four right valiantly, even beneath their very noses.

A very common bird-misnomer in my country is that of calling the whistling "Bob White," or Quail, a Partridge.

Our one and only Partridge is the Ruffed Grouse; or Pheasant-as many term him here and in the South; and even 


\section{A Book on Birds}

he is becoming rare in Pennsylvania, except in some mountain districts, where the drumming of his wings is still a well-known and highly cheerful sound, especially in winter.

However, Mr. "Bob White" (Partridge, or no Partridge) is a jolly good fellow just the same; and it is a source of regret that from causes not fully understood he also should be gradually disappearing. His trick of starting up like a flash at your near approach and flying straight away with the rush and roar of a misdirected rocket is quite inspiriting. It is the very thing, in fact, above all others, to enliven a birdquest which has lagged a little, perhaps; never failing to put one on the alert again for a while.

And Mrs. "Bob White," in turn (be it not overlooked) is interesting too; and exceptionally so, I think, when in company with her newly-hatched brood. Most birds emerging from "the great unknown" are naked and blind at first, and therefore unattractive in appearance; but not these, 


\section{Midsummer Memoranda}

who run about when but a day or two old as wide-awake, chipper, and fluffy-clad as chicks of that age, feeding and drinking and helping themselves without assistance, though only a trifle bigger than a thimble.

They consequently make about as dainty and delightful a spectacle as may be found in nature.

Years ago (really at an altogether remote period in my career) I used to find that a few full-grown Quail insisted occasionally in getting into certain pyramidal wooden rabbit-traps of which I then had supervision every winter. The statute of limitations having run in the matter about a dozen times over, both as to traps and birds, I have no hesitation in saying that my duty to release these victims was generally honored in the breach-friends of mine in those days considering quail-on-toast a delicacy not to be lightly disregarded.

The big, high-sailing birds that float along through the upper atmosphere-with widely-extended, motionless wings, above the shimmering heat and stillness of an 


\section{A Book on Birds}

August afternoon, are either Turkey Buzzards or Red-tailed Hawks in our latitude. And often it is hard to tell them apart under such conditions; not only their manner of flight being practically the same, but also their breadth of outspread pinions. A marked point of dissimilarity, however, for those who must identify them in the air, if at all, is that the Buzzards appear entirely dark in color underneath, while the Hawks are of a light grayish hue which has the effect of making them seem to vanish for a moment whenever the sun shines full against it. Beside this the former are longer of neck, and, though assuming the same pose when flying, proceed in a straighter course than the latter, who move about as a rule in great, sweeping circles.

The Red-tailed Hawk, whilst not nearly as predatory as Cooper's Hawk, so much dreaded by many farmers, is nevertheless by no means as serene and peaceable at close quarters as he purports to be from afar.

I remember well how as a boy of eight or nine attending a very primitive little public- 


\section{Midsummer Memoranda}

school up in the country I saw one drop like a shot from just such a smooth and quiet voyage, seize in his talons a fat hen from amongst a small fiock of poultry in a yard adjoining our play-ground, and rise rapidly with it directly overhead.

Hungry and rapacious as he was, however, the sound of fifty or sixty lusty young voices, raised in a simultaneous shout, was too much for him; and at a height of probably two hundred feet he let go his prey and it came flopping to earth, landing with something of a thud, yet none the worse for its sudden and unexpected excursion.

Another vigorous bird of this same general family is the American Osprey, or Fish Hawk. He is rather handsome in appearance, being brown of wing and tail and white-breasted. Although really a shorebird, I have seen him take fish quite a number of times in the Schuylkill and Perkiomen, and on each occasion he went into the water at an angle, and with a great splash, and came up with the wriggling 


\section{A Book on Birds}

victim clutched in a position parallel with his own body, probably because he found it easier to fly this way.

The Great Blue Heron, or "Big Crane," is a very different sort of fisherman. He is awkward on the wing, mounting up through the tall trees in a wood with his long legs dangling straight down below, and trailing them clumsily after him as he moves forward, when once he gets out in the open.

Yet he is not always ungraceful by any means, but often distinctly dignified and elegant, whether standing or walking, or even while engaged in his ordinary piscatorial diversions. He goes into the water only to his knees, and most deliberately, and uses his long yellow bill with considerable art. A full sized bird of this species will sometimes measure nearly four feet in height; more than half this dimension, however, being of course mere neck and legs.

In his case it is quite easy to understand why walking is a better method of locomotion than hopping, which would probably 
be about as difficult for him as for a youngster on stilts. But with many other aquatic and semi-aquatic birds, all of whom walk, the reason for it is not one whit more plain than with the land-birds who do so, like the Quail, Blackbird, Goldencrowned Thrush and Meadow Lark.

My general observations as summer advances toward a close, incline me to the opinion that birds get more real fun out of life well on in August than at any other time of the year.

Having finally disposed of the thousand and one cares of rearing a brood and training it to fly, they seem to relegate the matter of music largely to the locusts, that they may give themselves to pure frolic with absolute abandon.

It is evidently their true vacation time, just as with most men and women; and with one accord they all appear disposed to use every minute of it to the very best advantage.

And how perfectly fitted for play they are, indeed! I have watched squirrels 


\section{A Book on Birds}

chasing each other merrily from limb to limb and tree to tree in the deep woods and found it delightful; but a pair of wings (to my mind) must make mere sport ideal.

I find that many of the smaller species are already going about in flocks. In fact the fun they have could scarcely be quite so general or so jolly except for this. Some games no doubt must be played with only one or two-on the wing as elsewhere; but nature shows a preference, at least just at this season among birds, for the more generous sort.

Companies of Chipping Sparrows, browncapped as ever and quite unchanged in plumage either by rain or sunshine since April, may be seen by almost every roadside-each group numbering perhaps twentyfive or more.

They prove that a Quaker garb does not always indicate a lack of sprightliness of spirit by any means; nor an empty nest, a broken heart. They are as lively and sociable as crickets, despite their plain 


\section{Midsummer Memoranda}

clothes; and their deserted homes (woven of dry grasses on the outside and horsehair within and just as neat as ever) do not disconcert them in the least, though they may be easily discerned in the larger bushes or the lower branches of small trees.

One of the special signs of the year is that Goldfinches and Indigo Buntings are evidently increasing in number in my locality, a circumstance rendered very pleasant by the fact that both these little birds are of brilliant plumage and sing a great deal, even on days when almost all the others are silent. Their music will become familiar when once you notice, as I have hereinbefore hinted, that the Indigo Bunting's strain is simply the Goldfinch's rattled off in double-quick time. I hear him doing it this moment as I write-like a boy with a piece of cake, hurrying as hard as he can to get through with what he has in hand, that he may instantly begin all over again on a new effort. 


\section{A Book on Birds}

Notwithstanding his impetuousness, however, he is certainly a beauty; and I like him none the less for the way in which he is beginning to come right into my town itself with increasing familiarity almost everywhere.

I recently met with more of these birds in one place than I ever before saw in a single afternoon. It was immediately following a severe thunderstorm which caught my car and held it up for a half hour near the top of Skippack hill.

The approach of this storm-seen from this eminence, with its angry, low-lying clouds rent by great flashes of lightning and its dense sheets of driving rain-was a most magnificent and awe-inspiring spectacle; and the down-pour when it reached us was tremendous while it lasted, flooding all the roads and turning every rut into a rivulet.

But in a short half-hour the sun came out more brightly than ever; and by the time I arrived at Tanglewood lane, some two miles farther on (a rendezvous which 


\section{Midsummer Memoranda}

I have already described), the birds had come out too-especially my iridescent Indigo friends just mentioned.

As I entered our delightful by-way once again-more secluded, more fragrant, more woodsy than ever, I espied them in every direction. Countless rain-drops sparkled on all the vines and bushes and trees around and above me (for I found the road almost completely overarched now from end to end by wild grape and cherrythe branches of the latter laden with ripened clusters); and this glittering splendor, coupled with a hundred melodies of running water from both sides, seemed to fill the singers with great joy

They warbled incessantly and tumultuously, and soon started many others a-going-including even two big crackedvoiced Blue Jays, who hurried right across my path in their gayest plumage with a young one trailing on behind; and then, an anything but cracked-voiced Brown Thrasher, who wouldn't let me see him, yet sang his sweetest just the same. A 


\section{A Book on Birds}

Cardinal also whistled for me (this is a favorite haunt of his), and by the time I reached the Perkiomen I had heard or seen many others, all apparently glad as I was for the cooling and refreshing of the rain. 


\section{Five Mile Run}

\section{Five Mile RuN}

(The Stony Creek)

\section{Dear little man-do you mind the brook}

Called "Five Mile Run," and the route we took To reach it by that last small street

Where the sky and the old town seemed to meet?

And how glad we were, little man-do you mind?-

To leave the noise and the heat behind,

And feel the houses were out of sight

And we needn't be back again till night!

How we stopped to hark, where the willows grew,

For its first, faint music stealing through?-

That limpid stream, with its rippling song,

That laughed with joy, as we came along,

Through bush and bramble, by vine and tree,

Lured by the wilding melody!

How we kept together, and, crouching low,

Caught deep, bright glimpses of its flow

Down, down through a dim and leafy maze,

All woven with branches overhead,

That closed at length on its silver thread

And set a bound to our eager gaze?-

Yet not to our feet which followed still,

Sure to find again our merry rill!

And then, do you mind-dear little man,

That break in the woods where the water ran

Right into the open for half a mile,

To go to sleep in the sun a while? 


\section{A Book on Birds}

How we loved those fields, so broad and fair, With the blue above, and the Lark's clear call, And the big, white clouds high over all, And the fragrant, breezy, golden air! And then-that place on its winding way, Where the water spread to a little bay

On which the ducks kept holiday!-

Dear little man-do you mind that too?

Ah me, ah me, if I only knew!

For, behold, this very afternoon

Our brook is singing its old sweet tune;

And, lo, as I seek it, lone and sad,

I remember that woodland call we had,

And, hungry to hear you, fain would try

To lift it again through the trees to the sky.

Yet I will not doubt-I will not fear!

For at times in the stillness you seem quite near;

And your face is always so full of joy

That I think, with a thrill-my own dear boy-

You perhaps have discovered where you have gone

Some stream just as lovely as "Five Mile Run"! 


\section{Chapter XII}

BIRDS ON THE WING

THE migration of birds, northward and 1 back again, spring and autumn, across countries of the temperate zone, is one of the deep and fascinating mysteries of nature.

First of all, the fact that many species make these semi-annual voyages of theirs through the upper air entirely during the silent watches of the night, sometimes traveling perhaps as much as five hundred miles through the darkness in one flight from sundown to sunrise, is in itself both surprising and wonderful.

They are probably passing by the tens of thousands as I write (October tenth) and have been since the middle or latter part of September, every time I have given myself to sleep; and, save for an occasional "peep-peep-peep," heard faintly from 


\section{A Book on Birds}

above, somewhere between me and the stars, they sweep onward in absolute silence amidst the encircling gloom.

And then-most strange in this whole matter-the ones that choose the night without exception for the journey are the very smallest in size and those most delicately formed - the beautiful little Wood Warblers, many varieties of which may be found in large numbers almost any sunlit morning just now, in the immediate vicinity of my own country town, or even in the branches that overhang its very streets.

For be it remembered-though most birds of passage do fly all night - they cry a halt with each morning as it dawns, that they may rest and feed in turn all day.

Twenty of the species known as the Bluewinged Warbler were counted by me in one big buttonwood tree a mile or so away one morning-regaling themselves, with alert eyes and incessant hopping from twig to twig, upon some insect they seemed to find in this sort of tree alone; for although some were met with on each one of a dozen 



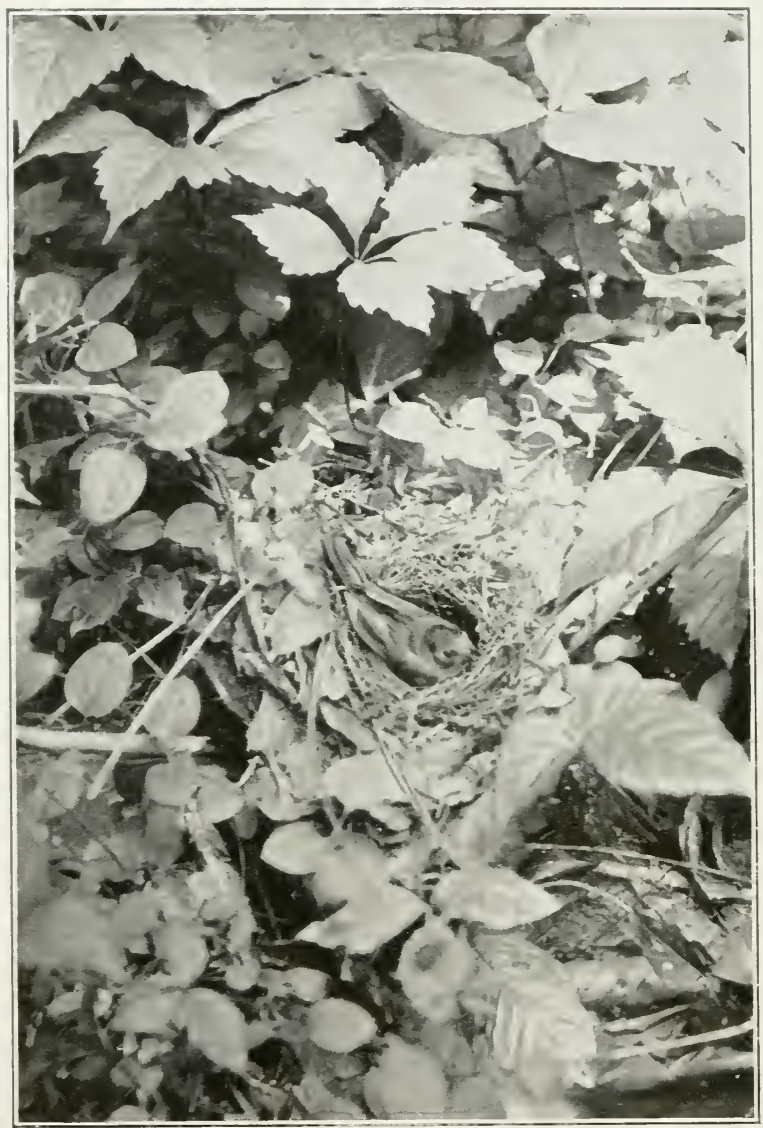

Fenale Kexteck Tarbler

(See page 164) 


\section{Birds on the Wing}

other trees of the same kind near by, none were visible anywhere else.

And how hard it was to detect their presence even with a good spy-glass to help! Unless I had been looking for them just in that neighborhood-having gained some knowledge of their habits in former years - they must certainly have gone undiscovered. One little, unmusical chirp gave absolute assurance indeed of their nearness amidst the autumnal silence; but, nevertheless, it took sharp and patient searching of the foliage after that to find them out.

And this with good reason, too. The God that fashioned the Blue-winged Warbler knew quite well that in its long, laborious flight straight as an arrow to the southland guided by the instinct which $\mathrm{He}$ gave, it must needs look to these very buttonwood trees in the morning for sustenance; so $\mathrm{He}$ arrayed it in color like unto the colors of the trees themselves, that it might rest undiscovered and in peace, and go unmolested as it fed. Wherefore its upper 


\section{A Book on Birds}

breast is rich yellow and its back green, like the tints of the frost-touched leaves; its undercoverts are of that indefinable hue of gray (like the shadow of an emerald) which marks so strikingly the branches and trunk of a buttonwood tree where the outer bark has peeled off; whilst its wings are made to match the blue and white of the cloud-flecked sky showing high above, through the foliage.

So baffling are these harmonies of color, not only with this species, but many others of entirely different tints (adapted also to the trees frequented by them) that these charming sojourners, even when they are with us in very large numbers, are as a matter of fact, seen by so few people that in a general way they are practically unknown. When they are pointed out the first time to an untrained observer he is nearly always incredulous for a whiledeclaring he can discern nothing overhead but the maze of branches and twinkling leaves. However, let him be but patient enough to fix just one wingéd beauty with 


\section{Birds on the Wing}

his gaze-and others will be sure to reveal themselves quickly thereafter, to convince him beyond a doubt; for they rarely migrate save in groups.

There can be no question that a prime reason for their traveling only at night is the remarkable length of time it takes them to feed. The same birds may be observed engaged at this quite important occupation right through an entire day, and just as busily too at dusk as at dawnwith apparently no time for flight, even were they inclined to it; all of which indicates that either their appetites are relatively prodigious, or that the food they feed on is infinitesimally dainty.

Another explanation for the migration of these smaller birds by night is that the darkness keeps them safe from attack by hawks, that could take them with ease on the wing were they above the trees in daylight, but find it impossible to get at them, or even discover their presence as long as they stick close to the friendly cover of bush or branch. 


\section{A Book on Birds}

A most interesting exception, however, to this rule of night-migration which prevails among so many is found in the case of the White-breasted, or Tree, Swallows, who invariably travel only from sunrise to sunset. They also start on their annual trips southward earlier than most of the others, often gathering in great flocks along the seashore by the middle of August and beginning their flight soon after. When once they are all marshaled and ready to proceed their numbers are simply astounding. A friend of the writer once saw tens of thousands of them gathered together of a September evening upon a stretch of beach near Surf City, New Jersey. They covered the sand thickly in every direction for several acres, like soldiers in serried ranks, all facing a stiff wind which was blowing from the northeast at the time, and he first thought them Chimney Swifts; but this was only because their backs were toward him at the moment, their pure white breastfeathers-snowy and spotless from chin to tail-showing a little later and fixing their 


\section{Birds on the Wing}

identity clearly; not to speak of the distinctively marvelous array in which he found them.

Of course, very many larger birds also migrate at night in addition to the smaller species. In the fall they have been found to move in three great flights, the first beginning about the middle of September and comprising those most sensitive to the chilly descent of winter from the north; and the last not taking place until late in November, when the hardy ducks and geese make the trip. It is said that the great mass of migratory birds this side of the Mississippi come east and follow the Atlantic coast line as they journey, most of them going down through a belt within a hundred miles of it. They keep at an altitude of probably three to five hundred feet in flying; and sometimes, if there be no moon, or the night be stormy, they meet with sad disaster by the way.

If you would know more upon this last point look up the keeper of the great arc lights at the famous William Penn tower 


\section{A Book on Birds}

of the City Hall, in Philadelphia. You will find him in a well-appointed office of his own away down amidst the mighty foundations, and he will tell you a most pathetic tale, running over a long period, of how his lofty circle of flaming lamps has wrought ruin to the birds of passage every year.

His men have found as many as one hundred and fifty-four dead or dying upon the pavement below of a single morning; and the total, since he has kept a record of them, has run up into the thousands, including about eighty different varieties, and over twenty kinds of Wood Warblers alone.

Moving through the air at a great speed even at night - as most birds do, some going as fast as a hundred miles an hour-the sudden blaze of light across their path at the tower blinds them so that they fail to see the grim and solid structure in the midst and are dashed against it. Most of them are killed outright, either by the force of collision or the fall to the ground in their stunned condition from so great 


\section{Birds on the Wing}

a height. Some few, however, survive under the tender care of the keeper or his men-but only a pitiable few indeed.

The collection of stuffed birds and bird skins at the Academy of Natural Sciences in that city has had many additions from the wayfarers that perish in this mannersome very rare species being among them; and the tower keeper himself will show you quite a number of valuable specimens of his own, gathered from the same sad harvest, all finely mounted - the tiny and exquisitely brilliant Redstart and Parula Warbler and the Ruby-crowned and Golden-crowned Kinglets being among the number.

This same thing of course occurs to a greater or less extent also at all high lighthouses on the coast. A friend who went down to the Statue of Liberty in New York harbor about nine o'clock one morning several years ago found four Baltimore Orioles lying dead at his feet as he stepped out upon the observation platform at the top. And similar stories come from other places. 


\section{A Book on Birds}

The aggregate number killed nevertheless will appear comparatively insignificant when one remembers how small a space all these obstacles together must occupy in the broad path of a hundred miles or so covered by these wingéd itinerants of the night, and how vast the multitude of them that pass on unscathed must therefore be.

"Peep-peep-peep!" I hear a lone and plaintive note or two even now through my open window as I drop off to slumber; and listening with a quick thrill of sympathy I wish each little pilgrim (though he leave the fields I love quite silent till the spring) Godspeed upon his way. 


\section{"I Travel Light"}

\section{"I Travel Light"}

I travel light-that I may bear The heat and burden of the day More buoyantly, and better share With others by the way What strength is mine, untaxed by things That heap the shoulders, and harass, The hands that would be free as wings

With healing, as I pass.

I travel light--not weighted down

With heavy harnessings of pride, And leaden love of vain renown

And lust of gold beside;

But trig and trim from foot to crown,

With swift reliance for my blade,

I fare me on from town to town,

Alert and unafraid.-

I travel light!

I travel light-that I may get

The further on this pilgrimage

Of mine amidst a throng, nor let

It all my time engage;

But gain an hour-now and then,

For sweet excursions, far and wide

From th' loud multitude of mèn

And traffic's weary tide, 


\section{A Book on Birds}

In helping of some heart more frail,

Or bowed beneath a deadlier blow

Than I have known-and fain to fail

For bitterness of woe-

Out, out to where the country yields

A calm surcease from toil and grief,

And all the fair and fragrant fields

Breathe rest and deep relief.-

I travel light!

I travel light-that I may keep,

Unhelmeted, my head on high

Toward the great hills of heav'n, where leap,

Eternal, to the sky,

Those upper fountain-springs of life,

Whose freshening waters fall below,

As dew, on pilgrims faint with strife,

To cheer them as they go

With an uplifting sense-and sure,

Of triumph even in defeat.

I travel light-who would endure

Must bear (for death is fleet)

Not weapons that but sap his strength

(Death-given, to betray his trust) -

But arms that in the end at length

Shall turn them not to dust.-

I travel light! 


\section{Chapter XIII}

\section{DICK}

TE was only a Yellow-bird. And not a paragon of his kind at that; but dull of color and even ungainly in appearance by reason of a droop in one wing, caused through some hurt before he found our fireside.

And yet he made himself altogether lovable by seeming to discover directly a beautiful mission amongst us.

Coming into a home enshadowed by the thought of a vacant chair not far away, around which the solemn silences of autumn were deepening, he behaved at once as though he knew all, and was determined to brighten things, if possible, to the best of his brave little heart.

And the measure of his success in this was wonderful.

We were half unconscious of it for a while, 


\section{A Book on Birds}

delightful as we found him; he was so subtle and exquisitely delicate in his methods.

But before long we awoke to a realization that he was illumining the season and our souls with the renascent gladness of an April sunbeam.

To begin with, he was the very quintessence of music;-music of the rare sort; not loud and noisy, like that of some of his folk; but sweet and low, soft and appealing - like the faint call of a brook from moss and fern through the forest, or the last echo of an evening bell in a distant valley beyond the hills;-music that drew you ever so gently from soul-ensnaring dreams at dawn, and lulled you back to them at night.

Sometimes it bubbled with the quiet laughter of joy for you-sometimes with the lighter and scarce audible laughter of affection; but always for you, always for you,-as if with every note he were thinking of your sorrow and striving that the darkness might never fall too heavily, nor the bleak winds quite pierce to the secret of your being. 


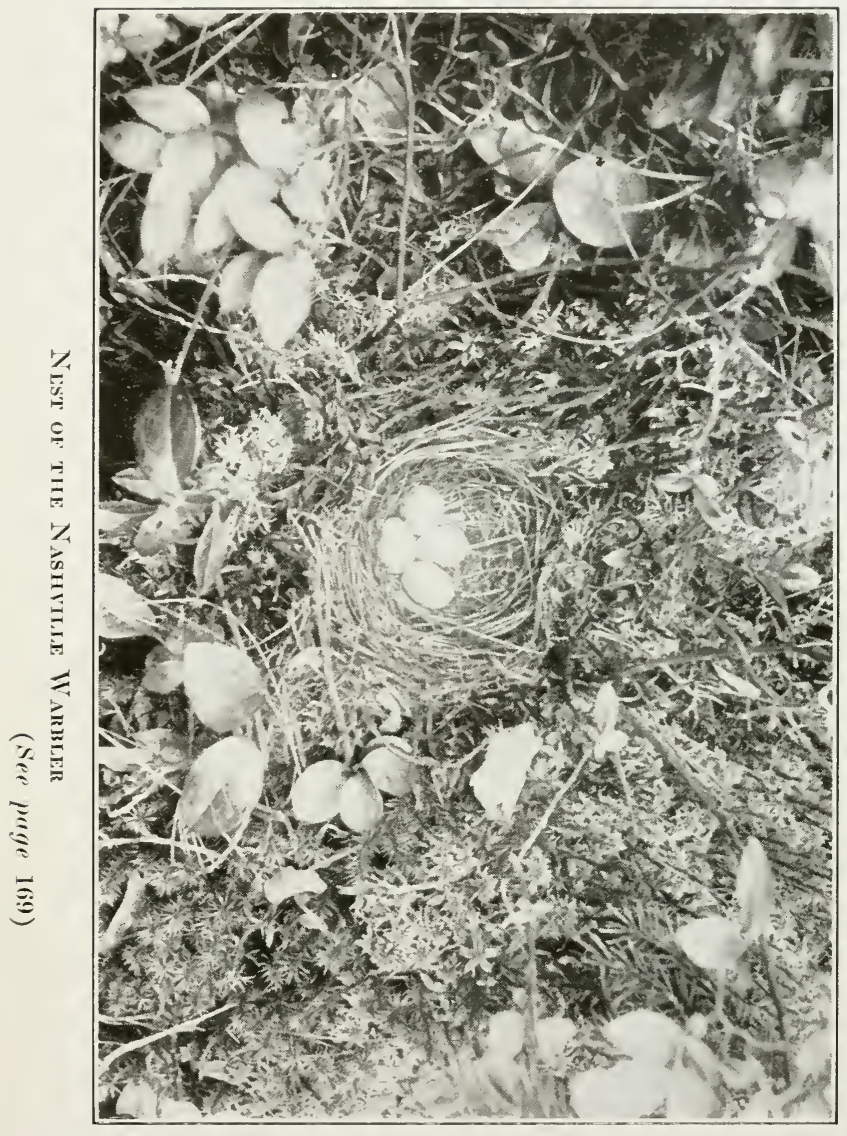





\section{Dick}

And he-only a bit of a Yellow-bird you could hold in the hollow of your hand!

Small wonder is it that the dwarf Cedar from the glen with its frozen fountainthe Cedar that keeps sturdy vigil all alone in the snow out front-looks very stern and grave this relentless afternoon because of the tiny dead thing we have just hidden in the brown earth at its feet!-small wonder is it! For the dwarf Cedar was kin to Yellow-bird, and stood near enough the door to know of his doings within.

And, ah me, how charming they all were!

When he wearied of singing he would call-wistfully, if you failed to hear; merrily, when you came.

And such fluttering followed!-such delight!-such nestling and withdrawal!such kissing of the lips, dainty as a snowflake on a rose!-such earnest scanning of the face and peering into the eyes, and chirping, and caressing and devotion!

Ah me, Yellow-bird! - was all this first in the Father heart that made you, to teach us how to love? 


\section{A Book on Birds}

And then, the even round of existence you led! The eating and the drinking and the bath; and the contented snuggling of the drowsy head under the wing for slumber in the dusk at close of day!

Ah me, Yellow-bird! - was this, this also, first in the Father heart that made you, to teach us how to live?

And then, finally, the brave front you showed at the end; with Thanksgiving day past; and Christmas; and even New Year's (when you circled radiant about the happy room, from one dear hand to another); with all these past, and death gripping at your slender throat; the brave, brave front you showed at the end!-till the dauntless eyes grew dim, and the saucy crest drooped down, and after a little there was nothing that remained but an embodied silence in feathery gold!

Ah me, Yellow-bird! - was all this too - even this, first in the Father heart that made you, to teach us how to die?

O, Yellow-bird, your coming and your going seem less in the stillness than these 


\section{To Persephoné Afar}

brief lines that tell of you! Yet they were not in vain! The pallid, silvery daylight of the "weariest month of the year" has something in it this February we never felt before; something of earth and heaven as indefinably sweet as the "shine of the soul of a seraph from the face of a passer-by."

\section{To Persephoné Afar}

Angel of the lengthening days, Beautiful with bloom,

To this bleak domain of winter Hasten through the gloom!

And with bird, and bud, and blossom

Following in your train,

Down upon its frozen fountains

Rain, rain, rain!

Rain your showers of love abundant,

Rain your floods of song;

Rain, oh, rain your joy resistless,

Till earth's captive throng, 


\section{A Book on Birds}

Held awhile in icy thraldom,

Quicken to the sound;

Wake, arise, and-laughing gently,

Leave the bonds that bound.

Hark, I hear across the distance

Even now your wings,

Beating glad the empyrean

Where the South-wind sings!

And at times the evening air

Seemeth strangely bright,

As with some mirage, reflecting

Your imperial flight.

While a thrill of deep expectance

Stirs the silent waste:

Angel of the lengthening days,

Haste, haste, haste! 



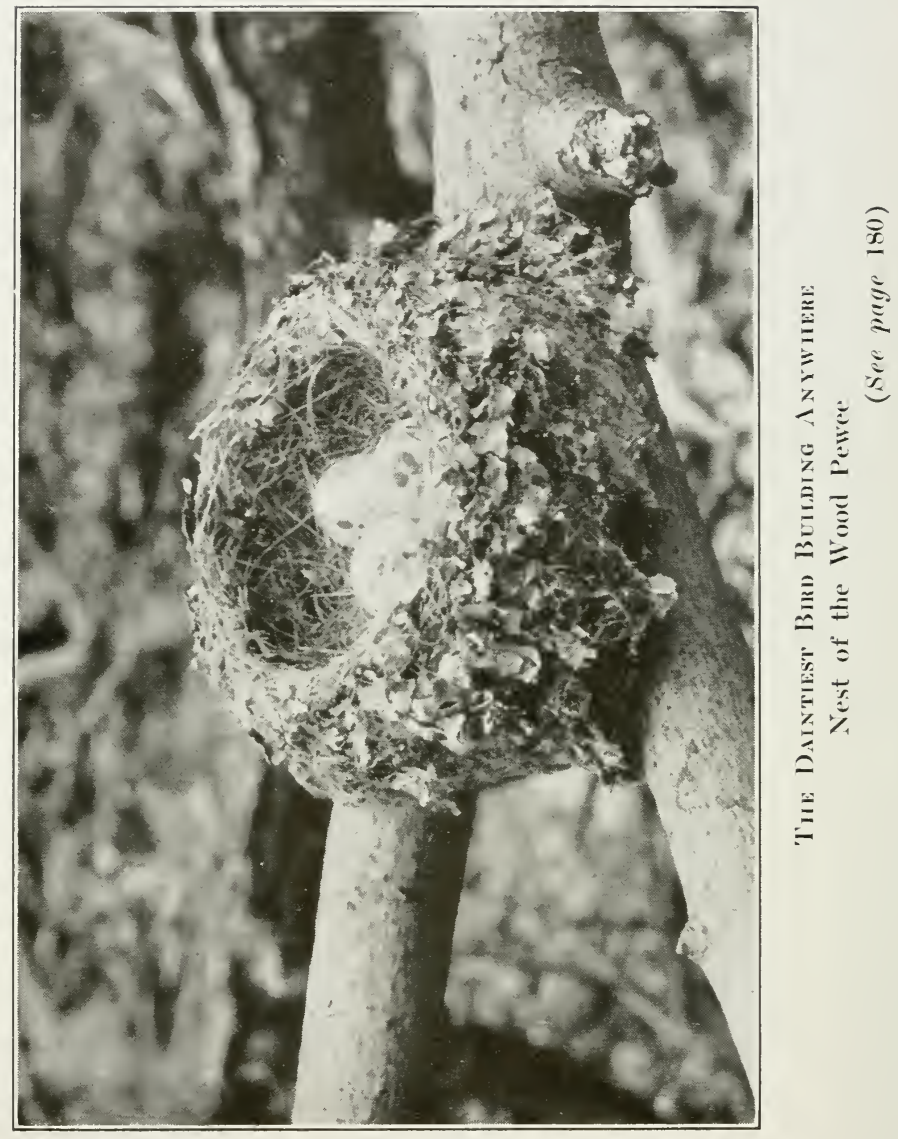




\section{Chapter XIV}

IN WINTER

THROUGHOUT this northern clime of 1 ours, winter would seem indeed an entirely unpropitious time for the study of life in nature.

And yet those to whom the tender "call of the wild" comes seductively at every season have found to their joy that field and forest are never altogether desolate, even in the bleakest weather, or amidst the heaviest ice and snow.

For, in spite of these, earth still remains bound to summer by many a golden link-each as subtle and lovely as the silken skein that kept Theseus in touch with Ariadne while he braved the black labyrinth of the Minotaur; and each but the more delightful when difficult to find.

It is probably true that the tracing of these hidden and elusive ties in winter is never easy. 
And it is particularly hard, perhaps, when we look to the birds for them.

Yet they do exist among the birds alsoas well as trees and plants and flowers; and when once discovered they convince us that in the great array of tender thoughts from heaven above which make nature precious to the soul, here verily is revealed the tenderest of all.

How many of us, for example, have quickened to the meaning of it, when we first learned that the little American Goldfinch, sunbeam of the tropics that he is!exquisitely fragile and delicate, remains right at our doors through all the bitter cold, when ten thousand others, sturdier than he, have fled?

By the middle of February his bright garb of yellow has turned completely gray because of all he has endured; and yet he holds his ground (his voice quite gone, but his merry flight just as merry as ever) until April showers shall have brought May flowers once again, and with the flowers all his vanished wealth of gold. 


\section{In Winter}

And the Goldfinch is only one-though in truth the most notable because he is so frail-of a fine and courageous company, all of whom remain, it seems, as cheery reminders from the sky that summer has not gone to stay, but is merely off on a visit for a while.

It is these birds that are always with us-these summer birds that make themselves our winter birds too-faithful in foul weather as well as fair-in time of hardship and privation, as well as sunny hours of ease-it is these that appeal to us most.

And there are two more in this class that merit almost equal distinction; first, the well-known Song Sparrow; and second, the Cardinal, or Virginia Redbird, whose flaming color on a snow-clad tree or hedge is a splendid sight, that must be seen to be fully appreciated. Several of these brilliant aliens from the South that so strangely forget their natural environment, appeared one February upon the pine trees of a large estate not far from my home- 


\section{A Book on Birds}

whistling away as though it were the middle of July. And I have seen others at more distant points-once as many as five or six in a single flock.

As for the Song Sparrow, he is often in evidence here and there and everywhere during the winter. The while his voice is gone he keeps in absolute seclusion. But two or three warm days are sufficient to thaw him out and bring it back in pretty good shape; and just the moment this happens, he loses no time in coming from his hiding-places and making it known.

One of this species has been doing this for several seasons on a vacant lot nearby my house, using the same wild-cherry tree on each succeeding occasion for his delightful vocal preludes to spring.

And may he continue the charming habit in other years to come-sturdiest, bravest singer of the fields!

Others of these-our own summer birds that never go away through the winter, are the well-known English Sparrow, the Crow, the Quail, the Downy Woodpecker,

$$
\text { [ 184] }
$$


and the hawks - the Sparrow Hawk showing himself perhaps most frequently of his family.

And this last bird, by the way, is sometimes as grossly misrepresented as any that flies. Instead of making Sparrows his daily prey and sustenance, as he is reputed to do, he turns his attention to them only on those rare occasions when he is absolutely driven to it in sheer desperation for lack of all other food, and is generally a quite innocent and harmless sort of fellow. In summer he subsists chiefly on grasshoppers and other insects, and field mice, in capturing which he often displays powers of vision that are marvelous-sometimes poising as high as three hundred feet in the air over a field of grass or clover, and then dropping like a bullet, with unerring aim, straight down upon the mouse he is after, in the tangled growth below.

The little Downy Woodpecker is altogether interesting and attractive. Furthermore he can be found almost everywhere and in the very roughest kinds of weather. 


\section{A Book on Birds}

Indeed he seems just built to brave the elements - with his chunky, well-knit body, big, comfortable wings, and thick coat of feathers. Even without all these, however, the amount of exercise he gets would of itself keep him warm; for he is the busiest and most energetic feeder in the woods, and during the winter seems to be eating simply all the time, working away incessantly on tree trunks and branches, with his tireless, red-tagged hammer-head, at the rate of about fifty pecks a minute.

His color scheme, though only black and white, saving the little patch of red just mentioned, is nevertheless brilliant because of its sharp contrasts - the broad, transverse bars on the wings being especially conspicuous and giving him a military air.

As I take leave of him here, and the others of this class who have long played chief part in brightening things for me in the open air while frost and snow prevail, I am reminded that there are a few more who, although not quite so sturdy and faith- 


\section{In Winter}

ful, nevertheless keep right close to the southern border-lines of my own country, and are indeed never so far away but that they are able to take quick advantage of every mild spell of any length at all for a stealthy excursion northward, even to my very door.

Included in this number are the Meadow Lark, Flicker, Kingfisher, the big, sweetvoiced Carolina Wren, and, as a matter of course, the Robin.

And now for the other class of birds wintering in our middle-Atlantic zonethose that spend their summers to the north of us, and are therefore not our own, but merely visitants during the cold weather.

Included in it are the ubiquitous Snow Bunting and the solitary Winter Wren.

I find these two together by going to a woods up along the Schuylkill, just this side of that same Indian Creek I have mentioned several times in these pages.

It is a picturesque place even in the bleak, declining days of February. 


\section{A Book on Birds}

The two men ahead, who look for all the world like trappers of a century ago and are threshing the likely-looking places "for a 'possum," in listless, half-frozen style, declare, in response to my query, that the brook of sparkling water which comes winding down through the trees over a half-dozen snowy cascades, "never had no name"-English which I once thought deplorable from a "newly-rich" lady at a reception, but which sounds all right out here.

The ice being broken (and the figure was never more appropriate than on this frosty afternoon), I switch off from the unchristened brook to the subject of birds, and find in a moment that the woodsmen know the Winter Wren and his haunts and habits quite well. "He hides in fence holes, and stumps, and logs," they say; "and under the banks along the water," I add, "where the half-exposed roots of trees form an overhanging shelter."

But just here you discontinue the dis- 


\section{In Winter}

cussion, for the bird himself flits by. $\mathrm{He}$ is very much like the House Wren in appearance-except that his short tail is even more than perpendicular, actually pointing toward his head. He don't seem "a scrap worried" over the low temperature, but is lively and active as a cricket in June. In seasonable weather he is a sweet singer-though just at this time of the year his voice has dwindled to the faintest echo of a chirp.

As he disappears and I proceed-I notice that others before me have followed the path I take; for the smooth, silvery bark of the beech trees on every side is covered with initials by the score.

In a minute or two the thin, rapid, warbling note of the Snowbird rises here and there in front of me-and then the singers themselves start up and forward, one at a time, right and left, to the number of twenty-five or more, their broad, white, lateral tail-feathers and bright buff beaks very prominent in the solid dark slate color of wings and back and head. 


\section{A Book on Birds}

Snowbirds in our climate always move about a great deal and usually in flocks, and are therefore easy to find and study.

And upon some other occasions I have seen them in even larger number and more lively mood than I find them to-day.

Once, indeed, with a northeast wind blowing and a snow storm imminent I came across probably a hundred of them in something of the same wild exuberance of spirit which marks a small boy when the first winter flakes descend. Instead of hunting for cover they were all in a mad frolic of aimless flight most of the time, circling after each other around and around in every conceivable curve, and flirting their wings as they alighted or started off again-the glistening tail feathers just referred to seeming like quick little flashes of light in the performance. It was from these, while perching here and there for an instant, that I learned a new strain of three or four notes with a clear metallic quality, like the sound produced by striking a small bar of iron lightly with a hammer. 


\section{In Winter}

And it was also on this same expedition, if I recall correctly, that I was first able to differentiate the music of the Tree Sparrow (another winter visitant) from that of the others of his family, two or three of this species repeating their song for me, with its two opening couplets, until I had succeeded in fixing it definitely to my entire satisfaction; yet not with the result of lessening my love for another strain-his cousin's cadenza, the bright and joyous one-twothree-count-the-rest-if-you-can melody of the Song Sparrow.

These few-home-birds and migrantswith the rarely seen Purple Finch; the little Brown Creeper, so hard to find because he blends so wonderfully with the bark of the tree to which he clings (being the best example within my knowledge of what is called "protective coloration"); the Golden-crowned Kinglet; a few Owls, and the merry, black-capped Chickadees,these, and perhaps one or two others, constitute the full array of our winter birds; not much of a showing, I grant you, and 


\section{A Book on Birds}

yet quite sufficient to make God's open air tenderly suggestive on many a frosty afternoon from December to middle March.

But really the interval of empty days of absence in field and forest has had very narrow limits during the winter in which I write.

Indeed, it was probably never before so brief. Even the summer birds - the Robin, the Blackbird, Meadow Lark, Goldenwinged Woodpecker, Killdeer, Bluebird and others, remained, many of them, almost until Christmas, and reappeared early in February; so that they were at no time very far away.

For nearly a month past, on sunlit mornings, the note of the Bluebird-the bird "with the earth tinge on his breast and the sky tinge on his back," has fallen mysteriously as I passed along the road, "like a drop of rain when no cloud is visible"; and during quite as long a time the spurting, gurgling strains of the Blackbird - who has real music in his voice only in earliest spring-time-have filled the tops 


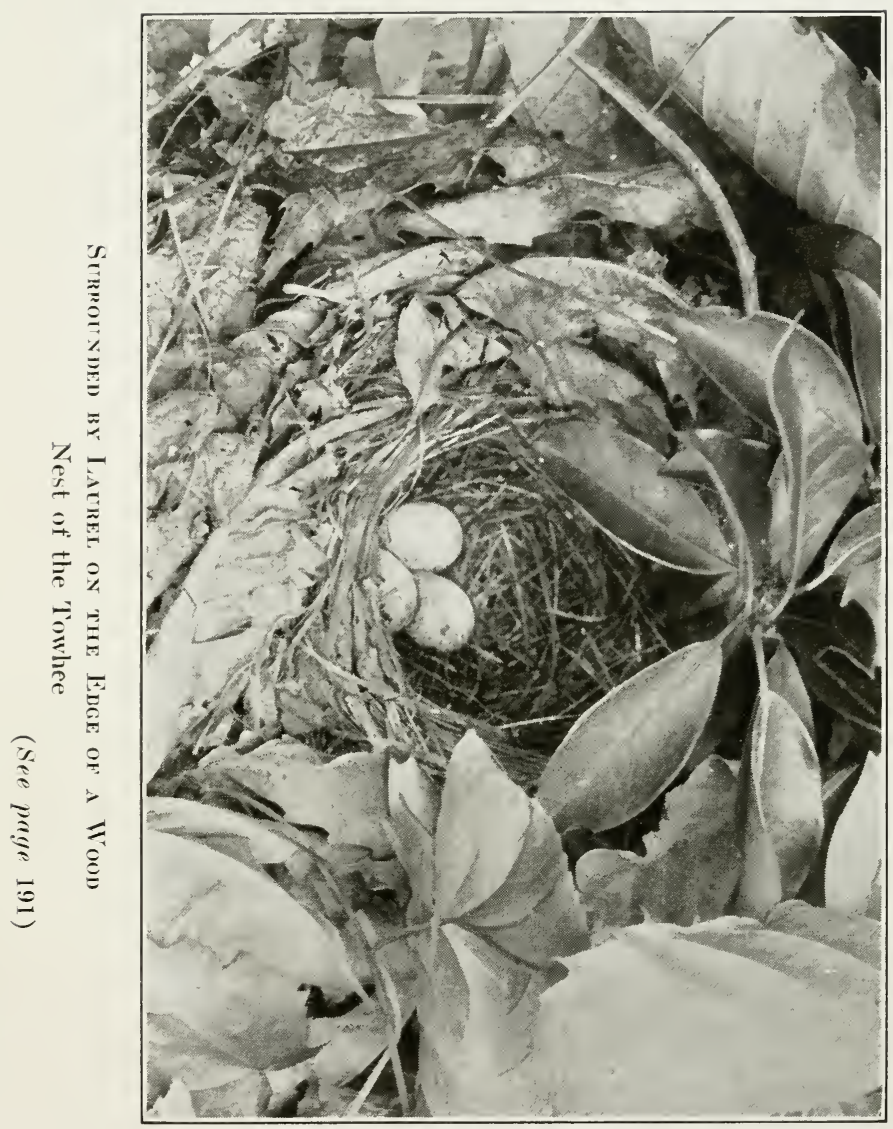





\section{In Winter}

of the pine trees. The vernal iridescence, which appears like a reflection of the light of April from afar upon his ebony feathers, already flashes its color as he flies; and the hope of better, brighter days in store seems nearer fruition than it ever was before while the year was still so young. 


\section{A Book on Birds}

\section{To A Goldfinch}

(Perched on a Thistle Weed above the Snow)

Little Yellow-bird, delaying

Bravely in a blighted land;

Left alone, but still obeying

Summer's sorrowful command;

She hath gone, but thou art token

Of her love, and wilt remain

Till, earth's icy thraldom broken,

She shall come to us again.

Winds may rail against thy gladness,

Fain to drive thee far away;

Winter hem thee in with sadness

Till thy gold be turned to gray;

All their hardship doth but make thee

Dearer than thou wast before, And as field and sky forsake thee

We but cherish thee th' more.

Thine unfaltering devotion,

(Sweet remembrancer, and true!)

Kindleth a divine emotion

Making us courageous too;

And, upon our spirits stealing,

Cometh strength to do and dare;-

Little Yellow-bird revealing

Springtime in the frozen air! 


\section{Chapter XV}

\section{FIELD KEY}

THE following list has been prepared as a special help and guide (ready at hand and as condensed as possible) for the use of readers of the foregoing pages.

It includes all those birds in the territory covered by this volume which the average amateur may look for with a well-grounded expectation of seeing within a reasonable period of time; but no others. And the distinctive purpose running through it is to characterize each species, not in a scientific way, but by its easiest, surest, and most obvious and apprehensible mark or marks (whether of color, flight, song, or some peculiar habit) for open-air identification by those who are not experts and never expect to be.

Within these limitations it is believed it is both accurate and informing, and will 


\section{A Book on Birds}

be found to contain practical clues to every new specimen which the ordinary observer is likely to meet with throughout this inland district of country.

The descriptive data of the entire list are those of the male bird only, full-grown, and also in his best plumage, which is generally in the spring.

The one unspecified dimension given is length of body from the end of the beak or bill to the tip of the longest tail-feather. It may be satisfactorily approximated offhand in each case by a beginner by comparing it with that of the Robin (our bestknown bird), which is ten inches.

No attempt at ornithological designation has been made in the key, other than that necessary to arrange the species in their proper order by families; and the author has even sought to lend to these fragmentary portions of the general nomenclature (with its odd Greek and Latin and many fanciful ideas) an elementary and popular interest by translating them into plain, everyday English. 


\section{Field Key}

\section{KEY}

PODICIPIDE (The Rump-footed Family).

Pied-billed Grebe (Little Dipper-Fish Duck). Migrant, and occasional winter visitor. Bristly frontal feathers. Upper parts, brown. Chin and throat, black. Lower breast, white. When swimming, moves as if walking in the water. 13 inches.

\section{URINATORIDE (The Family of Divers).}

Loon. Rare winter visitor. Largest diver, and therefore most easily recognizable from size, which is that of an average domestic goose. Back, black, spotted with white. Breast, white. Will swim as far as 200 yards under water at a stretch, remaining down as long as a minute and a half. 32 inches.

\section{LARIDE (The Family of Sea Birds).}

Common Tern (Wilson's Tern). Back and wings, light bluish-gray. Balance, white, with black crown. The "sea-bird" which most frequently finds its way up inland streams.

14 inches.

\section{ANATIDE (The Family of Ducks).}

Mallard Duck. Migrant, and occasional winter visitor. Largest Duck. "Deep-water" bird. Back, brown. Under parts, pale, dusky gray.

24 inches.

Wood Duck. Rare resident. Green and purple crest. Other colorings varied; some iridescent. Breast, white.

18 inches.

Blue-winged Teal. Common migrant. Occasional winter visitor. Dull lead color about neck and head. Blue patch on wing.

16 inches. 


\section{A Book on Birds}

ANATIDE (The Family of Ducks).-Continued.

Red-head Duck. Migrant. Rare winter visitor. Red head. Black collar. White breast. 22 inches.

Canada Goose. Likely to be seen only in flight, and then in this formation $>$. Black head and neck, with white "cravat." Dark back. Breast, gray of a varying tinge, making feathers appear like scales.

21 inches.

ARDEIDE (The Family of Herons).

American Bittern. Rare. Faded brown and black. 24 inches.

Great Blue Heron ("Big Crane"). Body, dull blue. Neck, white. Legs and neck, each about 16 inches long. Total height nearly four feet.

Green Heron ("Fly-up-the-Creek"). Brown and black, with black crest.

18 inches.

Black-crowned Night Heron. Black crest, out of which issue three long, white, flowing, filamentous feathers.

26 inches.

RALLID 2 (The Family of Rails).

Clapper Rail (Shore "Mud-hen"). Above, pale olive. Wings and tail, grayish-brown. Breast, buff. Chin, white.

14 inches. American Coot (Inland "Mud-hen"). Head, black. Rest, bluish slate-color.

15 inches.

\section{SCOLOPACID $\mathbb{E}$ (The Snipe-like Family).}

Spotted Sandpiper ("Tilt-up"). Long bill and legs. Abbreviated tail that bobs continually when he alights. Smooth, sleek plumage. Spotted head and cheeks. White breast.

$7 \frac{1}{2}$ inches. 



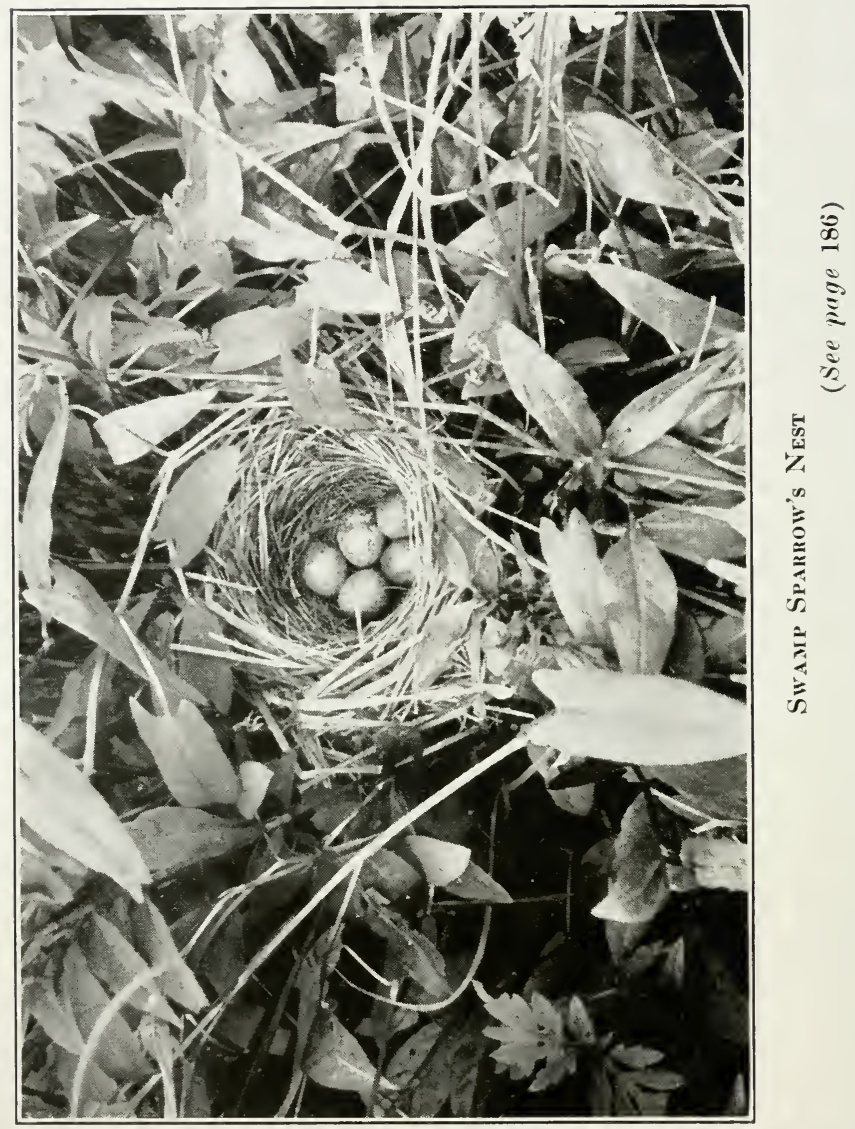




\section{Field Key}

SCOLOPACIDE (The Snipe-like Family).-Continued.

Bartramian Sandpiper (Field Plover). Speckled brown all over, except lower breast, brownish-gray. Distinctly recognizable from his shrill whistle in couplets, dropping from upper air, day or night. $12 \frac{1}{2}$ inches.

American Woodcock. Black, gray, russet, above. Brownish-red below. Body, stout and heavy, with short neck and long bill.

10 inches.

\section{CHARADRIIDE (The Family of Cleft-Dwellers).}

Killdeer. Upper parts brown. Under parts, pearlwhite, except black band across chest. Long, pointed wings with a crook in them in flight.

10 inches.

\section{TETRAONIDE (The Pheasant Family).}

Ruffed Grouse (Partridge). Black, brown, white; with big neck-ruff of black. Crested. 18 inches.

Quail ("Bob White"). Speckled reddish-brown, varied with white. Conspicuous throat patch; white in male, buff in female. Clear, loud, distinct whistle, deliberately given in a short series, one note at a time, with accent on the last.

10 inches.

COLUMBIDE (The Family of Doves).

Mourning Dove (Turtle Dove). Blue-gray and olivebrown. Smooth, swift, noiseless flight. 13 inches.

CATHARTIDE (The Family of Cleansers).

Turkey Buzzard. Entire plumage black, marked with dull brown. Wings pointed at ends. The big bird most frequently seen of those that float aloft with motionless, wide-spread wings.

30 inches. 


\section{A Book on Birds}

FALCONID EE (The Hooked-claw Family).

Sharp-shinned Hawk. Mottled gray breast. Red eyes.

14 inches.

Cooper's Hawk. Grayish-white, brown-mottled breast; back and tail very dark.

20 inches.

Red-tailed Hawk. Brown. Short, square tail, tipped with white. Under parts, white. Wings rounded at ends. The next most frequent motionless "high-sailer."

24 inches.

American Sparrow Hawk. Black and brown striped, above. Light buff, below. Flat head. Thick-set neck. Shoulders humped in flight. 12 inches. American Osprey (Fish Hawk). White, below. Brown, above.

25 inches.

STRIGIDE (The Family of Creakers).

American Barn Owl. Ashen face, heart-shaped. "The Monkey-faced Owl."

16 inches.

BUBONIDE (The Family of Horned Owls).

Snowy Owl. Rare. Largest of the Owls. Handsome white plumage, flecked with brown. 24 inches. American Long-eared Owl. Round face, brown-cheeked; ears rising up from forehead like plumes. 15 inches. Screech Owl. Red and gray. Eye-brows and ears forming a $\mathrm{V}$ on face. 10 inches. Barred Owl. Ashen-brown all over, with narrow, transverse bands of white.

20 inches.

Great-horned Oul. Large, and wisest-looking. Mixed black, brown, gray and white. "Horns" more like ears, because at sides of forehead; also, very conspicuous.

22 inches. 


\section{Field Key}

CUCULID $F$ (The Cuckoo Family).

Yellow-billed Cuckoo ("Rain Bird"). Above, grayisholive; below, white. Tail-feathers tipped with big white spots, some an inch or more long. 12 inches. Black-billed Cuckoo. Very like above in voice, markings and size; but bill all black; and white tips of tailfeathers very small.

12 inches.

\section{ALCEDINIDE (The Family of "Halcyon Birds" of the Winter Sea).}

Belted Kingfisher. Above, steel-blue; below, white with dark band across chest. "Pompadour" crest. Long, thick neck. Short tail.

13 inches.

\section{PICIDEE (The Family of Painted Birds).}

Downy Woodpecker. Transverse white bars on dark wings. Short tail. Small red spot on nape of neck.

6 inches.

Hairy Woodpecker. Markings very like Downy; but tail much longer.

9 inches.

Red-headed Woodpecker. Bright crimson head; rest, sharply-contrasted black and white. 9 inches.

Flicker. Under surface of wings yellow. Wave-like flight. Dark crescent patch on breast. Scarlet at nape of neck.

12 inches.

\section{CAPRIMULGID $\&$ (The Family of Milkers of Goats).}

Night-hawk. Thin, wide mouth. Grayish-brown and black. Conspicuous white spot on wing that looks like a hole in flight.

10 inches.

Whip-poor-will. Very like above; but reddish-brown and black, and no spot on wing. 10 inches. 


\section{A Book on Birds}

MICROPODID $\& E$ (The Small-footed Family).

Chimney Swift. Ashen-brown and black. Tail short, with spines. Pearl-gray chest. $5 \frac{1}{2}$ inches.

TROCHILIDE (The Family of Little Birds).

Ruby-throated Humming Bird. Green, above. White, below. Ruby-red gorget. 3 inches.

\section{TYRANNID瓜 (The Tyrant Family).}

Kingtird. White, below. Blackish, above. Small crest showing a red spot. Agitated flight. Piercing notes.

$8 \frac{1}{2}$ inches.

Crested Flycatcher. Dull olive and brown, with light yellow breast. Pinkish-brown under tail. Fine top-knot.

$8 \frac{1}{2}$ inches.

Phœbe. Olive-brown, above. Yellowish-white, below. Repeats name continually. Sharp eye. Small crest.

7 inches.

Wood Pewee. Olive-brown, above. Yellowish, below. Two pale-white wing-bars. Wings much longer than tail.

6 inches.

Acadian Flycatcher. Dark olive, above. Conspicuous white wing-bars. Throat and belly, yellow-white.

6 inches.

Least Flycatcher. Very like last, but noticeably smaller.

5 inches.

CORVIDE (The Family of Ravens or Crows).

Blue Jay. Pale blue. Conspicuously crested. White and black markings. Tail richly tipped with white. Loud, harsh cry. "A reprobate."

12 inches.

American Crow. Black, with violet iridescence.

19 inches. 


\section{Field Key}

ICTERIDE (The Family of Jaundice-Healers).

Bobolink. Glistening black and white, with buff cap, well back toward nape of neck. 7 inches.

Cowbird. Rusty, iridescent black. Grayish head. Metallic luster all over. 8 inches.

Red-winged Blackbird. Black, with bright scarlet spot on shoulders, of ten edged with yellow or white.

$9 \frac{1}{2}$ inches.

Meadow Lark. Upper parts, black and brown. Throat and breast yellow. Black crescent on chest. Outer tail-feathers white. Very rapid wing motion.

$10 \frac{1}{2}$ inches.

Orchard Oriole. Dull, faded red and black. 7 inches. Baltimore Oriole ("Hang-nest"). Brilliant orange and black.

$8 \frac{1}{2}$ inches.

Purple Grackle. Common Crow Blackbird. 12 inches.

\section{FRINGILLIDEE (The Family of Sparrows and Finches).}

(Many species of Sparrows will at first appear exactly alike to a beginner, and the special effort here made is to give only the most differentiating marks in each case.)

Song Sparrow. Gray and brown. Well-spotted breast, with blotch in center.

$6 \frac{1}{2}$ inches.

Tree Sparrow. In winter and early spring only. White bar on wing. Brown back, streaked with black, like scales. Breast, grayish-white with one indistinct spot in center. Brown of head, not a well-defined spot on crown like the Chippy's, but covering entire poll, and running even below eyes. Outer tail-feather, dull whitish. 6 inches.

Field Sparrow. Reddish bill. Bright, rufous brown back. Very light buff breast. Sweet, even, plaintive song.

$5 \frac{1}{4}$ inches. 


\section{A Book on Birds}

FRINGILLIDE (The Family of Sparrows and Finches).Continued.

Chipping Sparrow. Well-defined solid brown cap on crown. No "ring" in his notes. $5 \frac{1}{2}$ inches.

White-throated Sparrow. Dark brown stripes on head. Clear white patch at throat. 7 inches.

White-crowned Sparrow. In winter only. White crown, with rich black stripes. No throat patch. 7 inches.

Vesper Sparrow (Grass Finch). The sparrow that shows white tail-feathers flying.

6 inches.

Grasshopper (or Yellow-winged) Sparrow. Sings exactly like grasshopper. Crown, blackish. Bend of wing, bright yellow.

5 inches.

Fox Sparrow. Back, dull slate-color changing at rump to cinnamon-brown. Richly spotted breast. Largest sparrow.

$7 \frac{1}{4}$ inches.

English Sparrow. Brown and black, above. Chin and throat, black. Under parts, ashen-gray. $6 \frac{1}{2}$ inches.

Savannah Sparrow. Crown shows broad stripe of yellowgray.

5 inches.

Swamp Sparrow. Back broadly streaked with black.

$6 \frac{1}{2}$ inches.

Snowbird (Slate-colored Junco). Blackish-gray. Outer tail-feathers, glistening white. Flesh-colored beak.

6 inches.

Snow Bunting (White Snowbird). Beautiful glistening white plumage, flecked and streaked with rich brown. A most distinctive species, but rare.

7 inches.

Purple Finch. Dull drab and purplish-gray. Crown, ruffled purple. Rare migrant.

$6 \frac{1}{2}$ inches.

American Goldfinch (Salad, or Thistle, bird). Yellow, with black cap, wings and tail.

5 inches. 


\section{Field Key}

FRINGILLID $E$ (The Family of Sparrows and Finches).Continued.

Indigo Bunting. Iridescent indigo all over, but with black markings. Sings canary's song as if hurriedly.

$5 \frac{1}{2}$ inches.

Cardinal (Virginia Red-bird). Pale cardinal. "Duncecap" crest. Aspirated whistle. 9 inches.

Towhee (Ground-Robin-Chewink). Brick-red and black, with white markings. Whistles his name. $8 \frac{1}{2}$ inches.

Rose-breasted Grosbeak. Black and white, with bright rose running down from throat to breast.

8 inches.

TANAGRIDE (The Family of Tanagers).

Scarlet Tanager. Brilliant carmine body, with jet-black wings. Female, lemon-yellow.

$7 \frac{1}{2}$ inches.

\section{HIRUNDINID E (The Family of Swallows).}

(The distinctive mark of this family is their wonderful power of flight. All of them spend most of their time by day on the wing.)

Purple Martin. Largest swallow. Glossy blue-black all over. Tail notched, not forked; wings when closed extend beyond it.

8 inches.

White-bellied Swallow (Tree Swallow). Pure white below, from chin to tail; dark, metallic green above.

6 inches.

Barn Swallow. Deeply-forked tail. Steel-blue back. Chestnut breast.

$6 \frac{1}{2}$ inches.

Bank Swallow. White breast, banded with brown. Brown back.

5 inches.

AMPELIDES (The Family of Vine-Haunters).

Cedar Waxwing (Cedar Bird). Flattened crest. Body, light, dull drab and purplish-brown. Breast and edge of tail, yellow.

$7 \frac{1}{2}$ inches. 


\section{A Book on Birds}

LANIID (The Butcher Family).

Loggerhead Shrike (Butcher Bird). Migrant. Slatecolored, above. White, below. Wings and tail, black.

9 inches.

VIREONID (The Family of Vireos).

Red-eyed Vireo. Largest Vireo. Dull olive, above. Pearl, below. Eyes, ruby-red when sun strikes them.

$6 \frac{1}{2}$ inches.

White-eyed Vireo. Plumage very similar to above, but eyes white.

$5 \frac{1}{2}$ inches.

Warbling Vireo. Plumage very similar to above, but eyes black.

5 inches.

Yellow-throated Vireo. Colored like "Chat," but much smaller.

$5 \frac{1}{2}$ inches.

\section{MNIOTILTIDE (The Family of Moss-Pullers).}

(Most members of this family - the Wood Warblers-are merely spring and fall migrants in our latitude, Nearly all the smaller ones have dark brown eyes and are trim of body; and their most distinguishing family mark while with us is their voice in the trees, day or night; which as a rule is nothing more than a sharp little squeak.)

Black-throated Green Warbler. Cheeks and sides of neck, rich yellow. Chin and throat, black. Outer tailfeathers, white.

5 inches.

Black and White Warbler (Creeper). Black and white all over.

$5 \frac{1}{2}$ inches.

Blue-winged Yellow Warbler. Yellow, with blue-gray wings with two white bars.

5 inches.

Parula Warbler. Very small. Orange and yellow on upper breast, with faint tinges of same over bluegray back. Two white wing-bars. Greenish-yellow patch on back.

$3 \frac{1}{2}$ inches. 


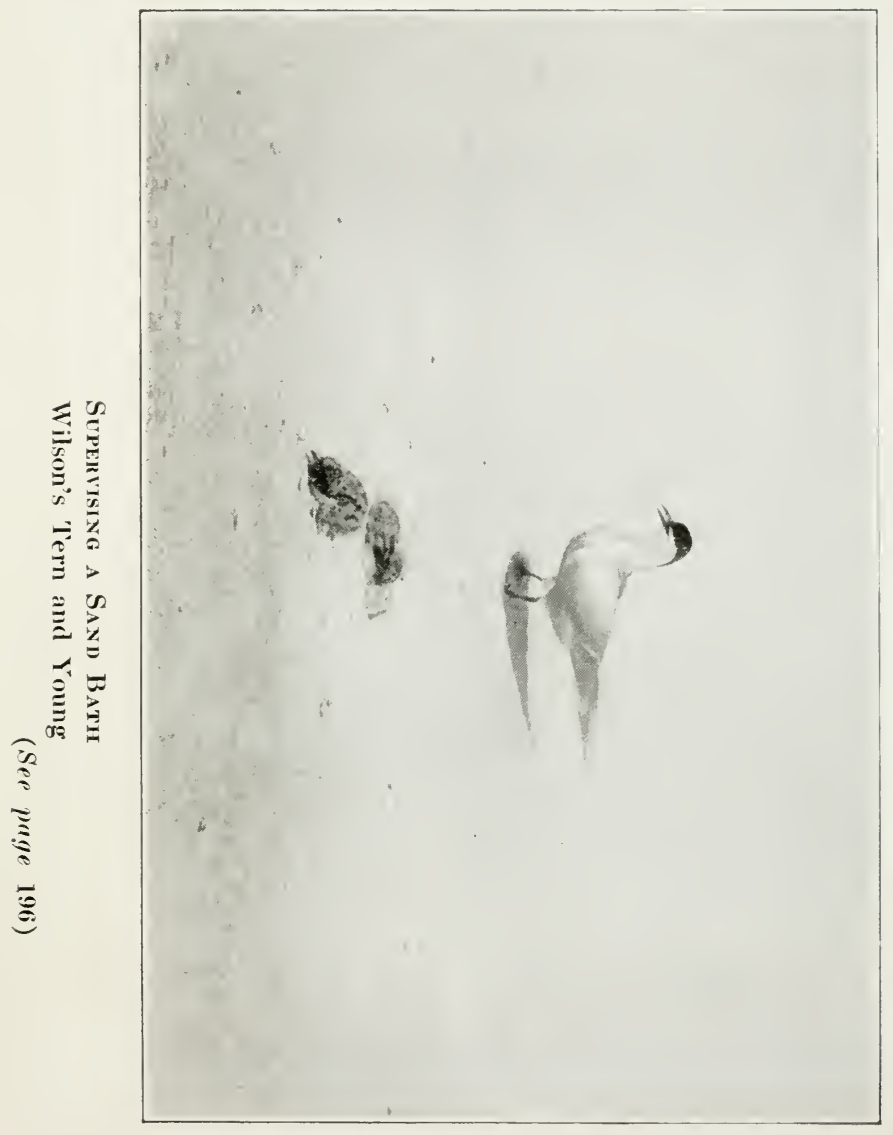





\section{Field Key}

MNIOTILTIDE (The Family of Moss-Pullers).-Continued.

Yellow Warbler. Yellow all over with little flecks of reddish-brown upon breast.

$5 \frac{1}{2}$ inches.

Black-throated Blue Warbler. Black throat. White breast. Dull blue back. White patch on dark wings.

$5 \frac{1}{2}$ inches.

Myrtle Warbler. Yellow on crown. Also on rump and sides of breast. Balance, blue, brown and white.

6 inches.

Magnolia Warbler. Crown gray and white. Yellow on rump, throat and breast.

$5 \frac{1}{2}$ inches.

Chestnut-sided Warbler. Chestnut stripe along breast, just below edge of wings. Crown, yellow. 5 inches.

Palm Warbler. Chestnut-red spot on crown. Back, olive or grayish-brown. Breast, yellow, flecked with brown.

$5 \frac{1}{2}$ inches.

Kentucky Warbler. Yellow, with black patch on face, along eye, but entirely below it.

$5 \frac{1}{2}$ inches.

Hooded Warbler. Yellow and olive with pronounced hood of deep black, which leaves eyes free. $\quad 5 \frac{1}{2}$ inches.

Maryland Yellow-throat. Yellow and olive, with band of black extended across forehead and eyes, like a blindfold, or "leather spectacles." 5 inches.

Worm-eating Warbler. Brown and buff-striped crown, something like that of White-throated Sparrow. Back, drab; breast, cream.

$5 \frac{1}{2}$ inches.

Nashville Warbler. Upper parts olive-green. Sides of head, gray. Breast and edges of wings, yellow.

$4 \frac{1}{2}$ inches.

Golden-crowned Thrush (Oven Bird). Slender and graceful. Mottled breast and other markings like Wood Thrush, with stripe of brownish-yellow through crown.

6 inches. 


\section{A Book on Birds}

MNIOTILTIDE (The Family of Moss-Pullers), - Continued. Yellow-breasted Chat. Olive, above; bright yellow, below. $7 \frac{1}{2}$ inches.

American Redstart. Orange and black.

$5 \frac{1}{2}$ inches.

Blackburnian Warbler. Orange spot on top of head. Chest, orange. Outer tail-feathers and wing-patch, white.

$5 \frac{1}{2}$ inches.

TROGLODYTIDEE (The Family of Cave, or Hole, Dwellers).

Catbird. Deep, smooth gray, with black markings. Brown under tail. 9 inches.

Brown Thrasher. Rusty brown. Very long tail and beak. Mottled breast. Golden-eyed. 11 inches. Carolina Wren. Largest Wren. Reddish-brown. Very long, curved bill. 6 inches. House Wren. Grayish-brown speckled. $\quad 4 \frac{1}{2}$ inches. Winter Wren. Speckled reddish-brown and black.

4 inches.

CERTHIIDEE (The Family of Creepers).

Brown Creeper. Dull faded brown and gray. Whitish, below. Long bill and tail.

$5 \frac{1}{2}$ inches.

\section{PARIDE (The Titmouse Family).}

White-breasted Nuthatch (Sapsucker). Gray, above. White, below. Black crown. Short tail. 6 inches. Tufted Titmouse. Gray, above. White, below. Conspicuous crest. 7 inches.

Chickadee (Black-cap Titmouse). Ashen-brown. Top of head, chin, and throat, black. 5 inches.

\section{[208]}




\section{Field Key}

\section{SYLVIIDE (The Family of Forest Singers).}

Golden-crowned Kinglet. Short, fat, trim. Dark green, above. Whitish, below. Fine spot of gold on crown.

4 inches.

Ruby-crowned Kinglet. Like above, but spot on crown bright carmine.

4 inches.

TURDIDE (The Thrush, or Fieldfare Family).

Wood Thrush. Brown. Pure white breast with rich brown blotches.

8 inches.

Hermit Thrush. Brown of tail very different from back.

Marks on breast in faint streaks.

7 inches.

American Robin. Red breast. Gray and black, above.

10 inches.

Bluebird. Bright blue. Upper breast, dull red.

$6 \frac{1}{2}$ inches.

Veery (Wilson's Thrush). Marked like first-named Thrush, but no contrast between brown of tail and back, which is of a dull cinnamon color. Slender and shy. Center of throat, belly and sides, white. Breast spotted.

7 inches. 







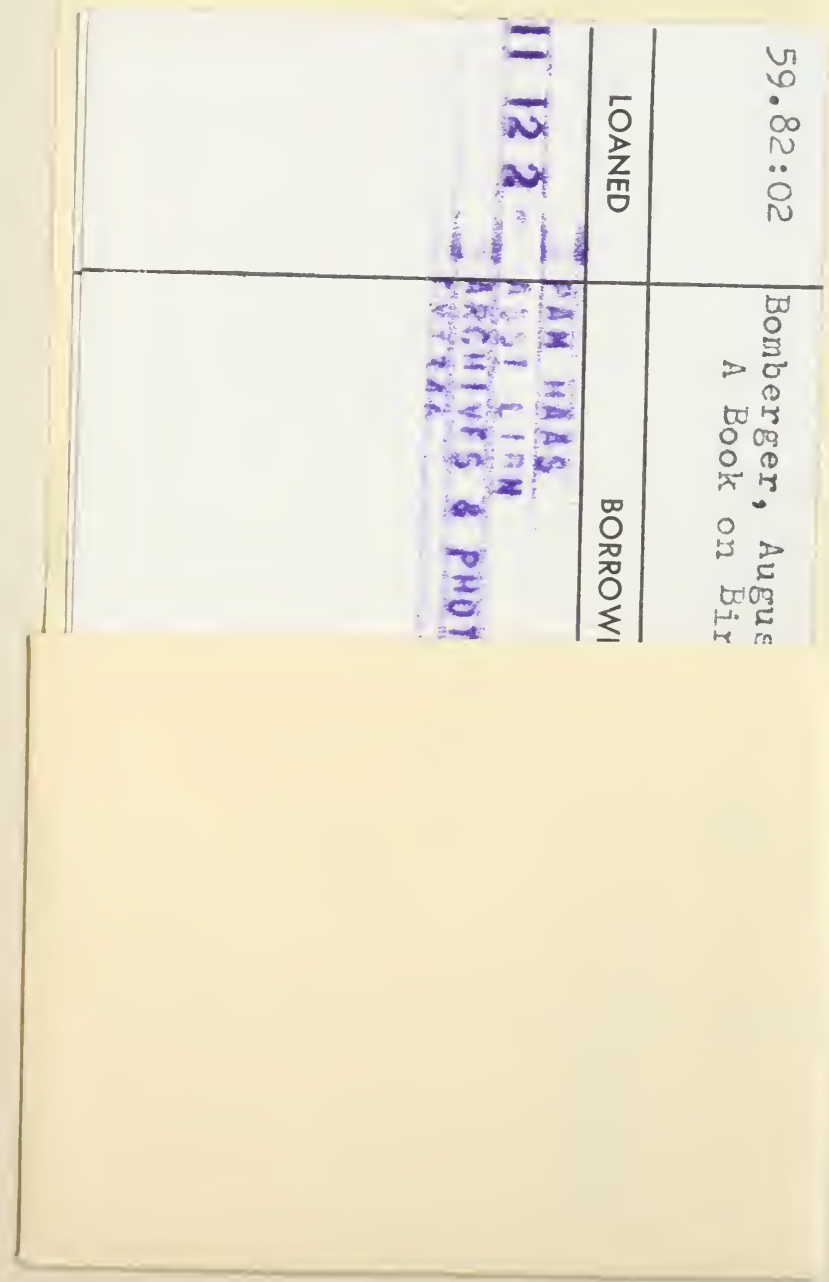


AMNH LIBRARY

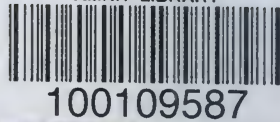

